\title{
Building a Predictive Model for Stratigraphic Transitions and Lateral Facies Changes in the Cretaceous Almond Formation, Wyoming
}

Joseph E. Phillips

Brigham Young University

Follow this and additional works at: https://scholarsarchive.byu.edu/etd

Part of the Physical Sciences and Mathematics Commons

\section{BYU ScholarsArchive Citation}

Phillips, Joseph E., "Building a Predictive Model for Stratigraphic Transitions and Lateral Facies Changes in the Cretaceous Almond Formation, Wyoming" (2020). Theses and Dissertations. 8731.

https://scholarsarchive.byu.edu/etd/8731

This Thesis is brought to you for free and open access by BYU ScholarsArchive. It has been accepted for inclusion in Theses and Dissertations by an authorized administrator of BYU ScholarsArchive. For more information, please contact ellen_amatangelo@byu.edu. 
Building a Predictive Model for Stratigraphic Transitions and Lateral Facies Changes in the Cretaceous Almond Formation, Wyoming

\author{
Joseph E. Phillips
}

A thesis submitted to the faculty of

Brigham Young University

in partial fulfillment of the requirements for the degree of

Master of Science

Samuel M. Hudson, Chair

Scott M. Ritter

John H. McBride

\author{
Department of Geological Sciences \\ Brigham Young University
}

Copyright (C) 2020 Joseph E. Phillips

All Rights Reserved 


\begin{abstract}
Building a Predictive Model for Stratigraphic Transitions and Lateral Facies Changes in the Cretaceous Almond Formation, Wyoming

Joseph E. Phillips

Department of Geological Sciences

Master of Science
\end{abstract}

The Cretaceous Almond Formation, located in the Greater Green River Basin, records deposition of coastal plain fluvial sandstones and shallow marginal-marine sandstones in a net-transgressive sequence along the western margin of the Cretaceous Interior Seaway (CIS) from the late Campanian to early Maastrichtian. The Almond Formation is an important hydrocarbon reservoir, with development mainly along the Wamsutter Arch and the northeast margins of the Washakie Basin. Previous studies have primarily focused on outcrops along the eastern flank of the Rock Springs Uplift and subsurface data targeting the Wamsutter Arch. Further development of the Almond petroleum system requires extending our understanding of lateral facies changes and sequence stratigraphic architecture away from areas that have been previously studied.

The aim of this research is to build a predictive model of lateral and temporal facies transitions and associated reservoir character along the Cherokee Arch in southern Wyoming. Outcrop examination at either end of the arch shows that lower Almond strata along the western margin of the Washakie Basin transition from coastal plain facies associations to time-equivalent shallow-marine strata to the east, while the upper Almond strata transition from shallow-marine sands to offshore and prodeltaic muds across the $\sim 125 \mathrm{~km}$ separating the two outcrop localities. This reveals clear facies associations shifts at the basin scale, which are difficult to interpret using only well data. The preservation of shoreface strata and related near-shore, fluvio-deltaics across large distances in the dip direction shows the large magnitude of shoreline migration. This also suggests that the system gradient was likely very gentle, leading to wide facies belts, and that reservoir continuity could be complex over significant distances.

Stacking patterns observed in outcrop, core, and log curves demonstrate an early progradational sequence across the basin from the west to east. This time equivalent strata suggests sediment supply outpaced accommodation during deposition of the lower Almond and equivalent basinward strata, leading to progradation and eventually to some aggradation before relative sea-level rose. This is significant as the Almond is thought primarily as an overall retrogradational system. Within the upper Almond and basinward equivalent strata, stacking patterns reveal a well preserved retrogradational sequence as accommodation outpaced sediment supply during the final transgression of the Mesaverde Group. Core and outcrop analysis to the east at this time show facies associations that potentially represent an inundated, estuarine deltaic environment of deposition transitioning to deltaic depofacies to the west. Clinoformal and lobate geometries corroborate a deltaic interpretation.

Outcrop, core, and subsurface datasets have led to a better understanding of sediment partitioning and preservation during this transgressive phase of the CIS in the western United States. A better understanding of these spatial and temporal patterns will help to remove risk associated with exploration along this trend, as well as serve as an analogue for other transgressive deposits.

Keywords: Almond Formation, sequence stratigraphy, facies analysis, subsurface correlation, photogrammetry, chronostratigraphy, Cherokee Arch, Washakie Basin, core description 


\section{ACKNOWLEDGMENTS}

Funding for this research was provided by Dominion Energy and supported in many ways by Brent Greenhalgh. I would like to thank my mentor, Sam Hudson, for all of the time and energy he gave to this research, but also for the space he gave me to lead my own research. A big thank you to Chelsea Jolley, Blake Steeves, and Eli Lopez for braving the Wyoming wind to assist me with my field work. Thank you to my brother, Stephen Phillips, who was not only a mentor to me for this research but is one whom I will always look up to. Finally, I want to thank my incredible wife who sacrificed immensely and supported me through this challenge. 


\section{TABLE OF CONTENTS}

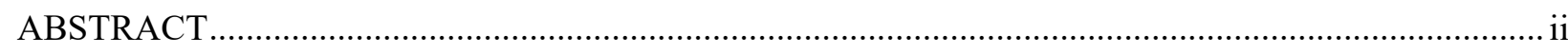

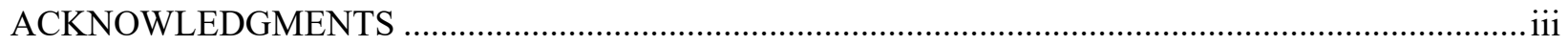

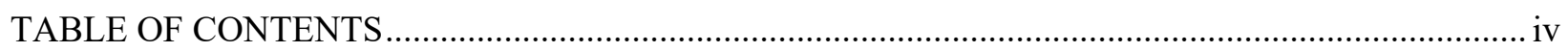

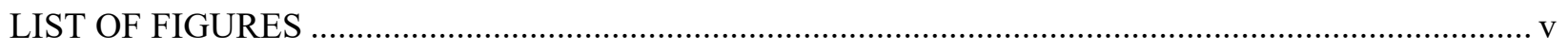

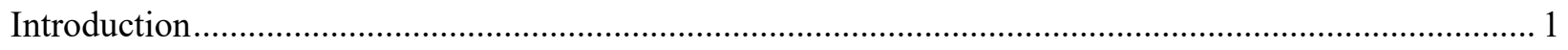

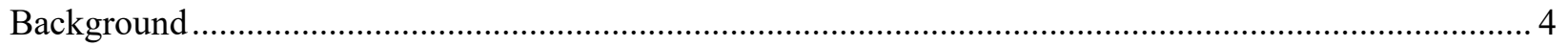

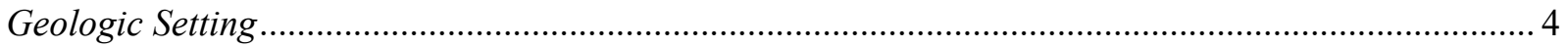

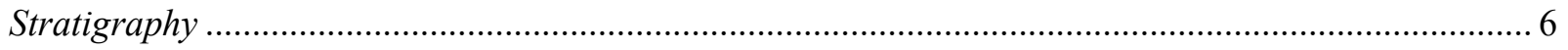

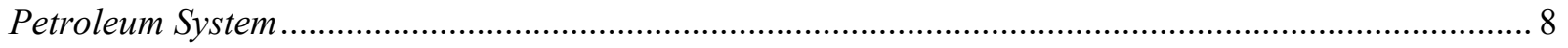

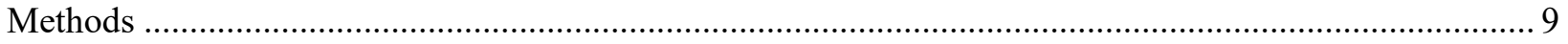

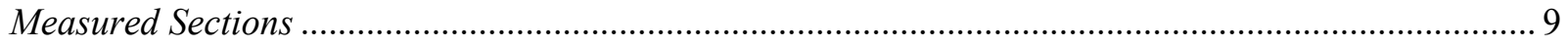

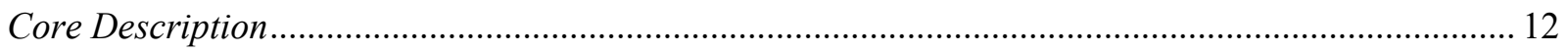

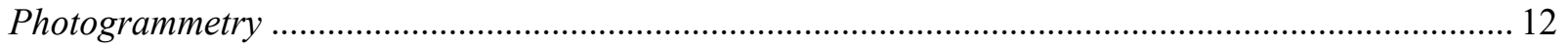

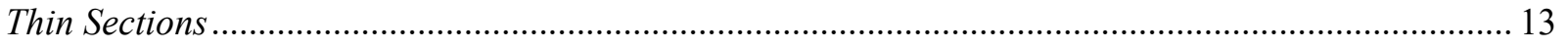

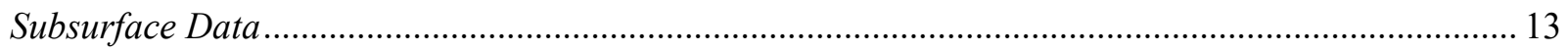

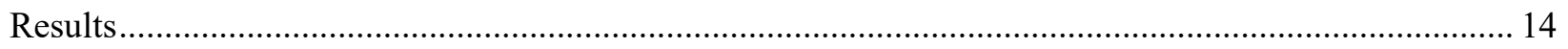

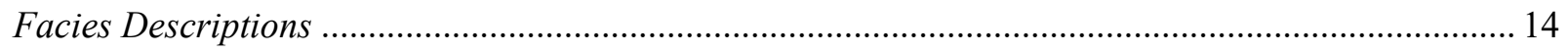

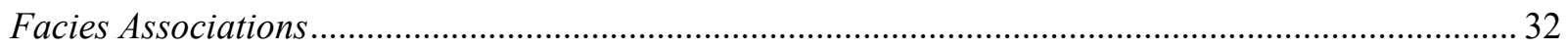

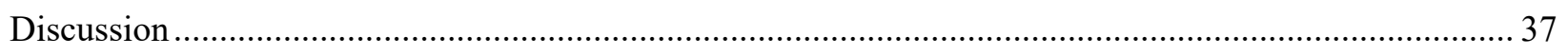

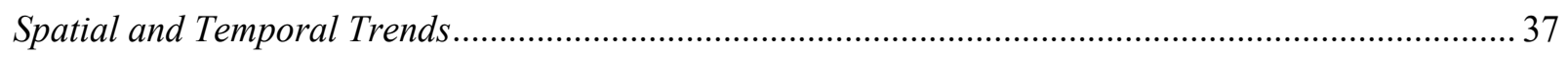

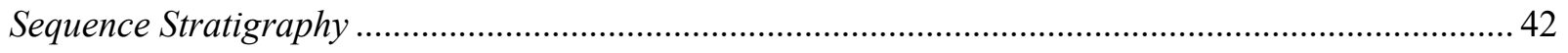

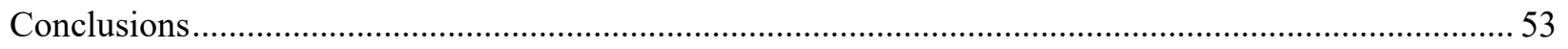

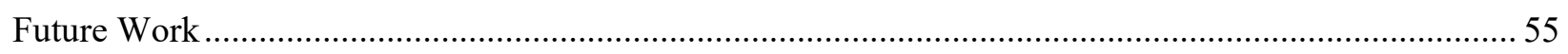

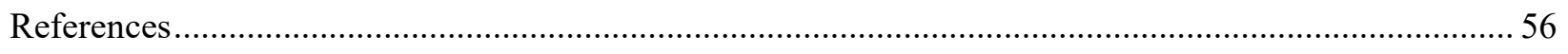

Appendix A: Drafted measured sections/core description................................................................. 61

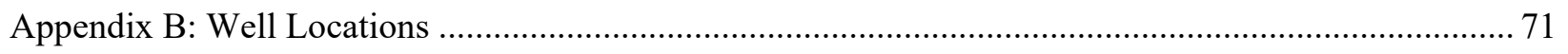




\section{LIST OF FIGURES}

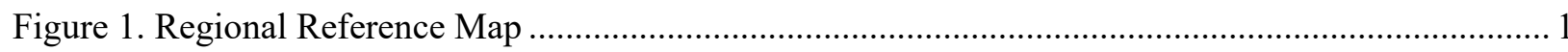

Figure 2. Regional Map Showing Structural Relationships............................................................ 2

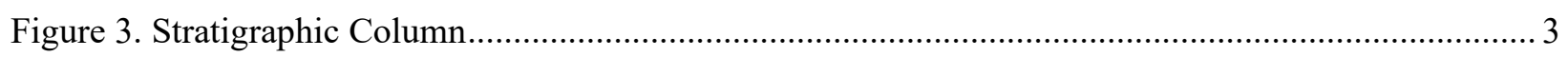

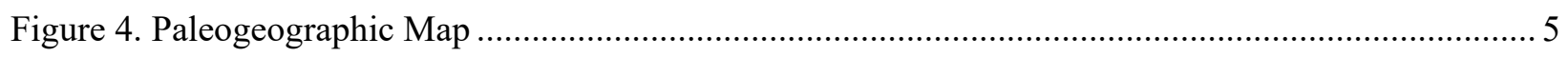

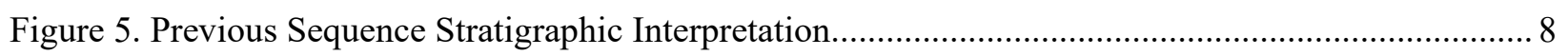

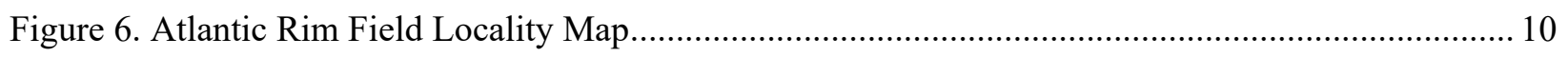

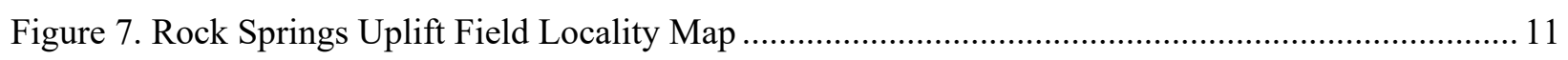

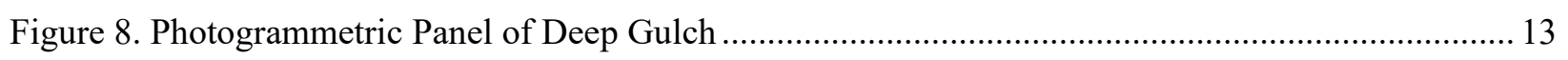

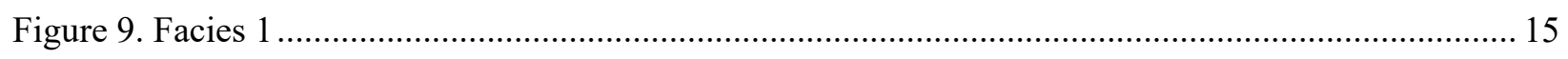

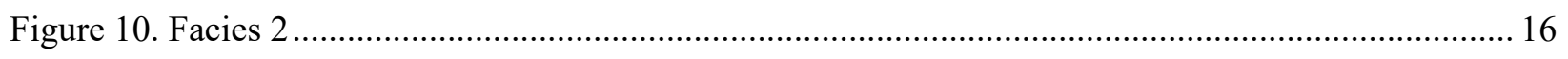

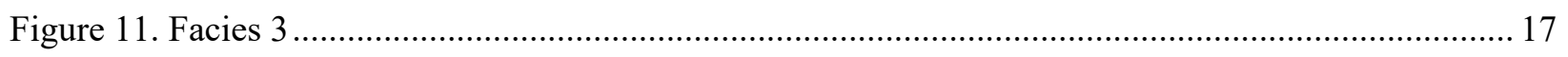

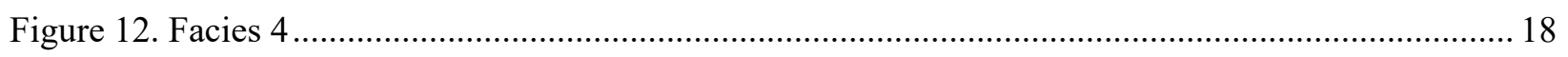

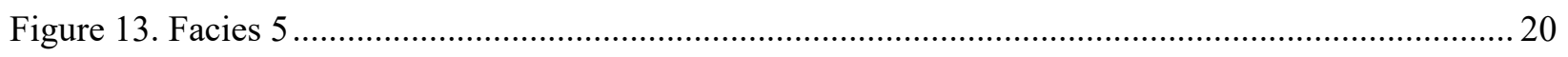

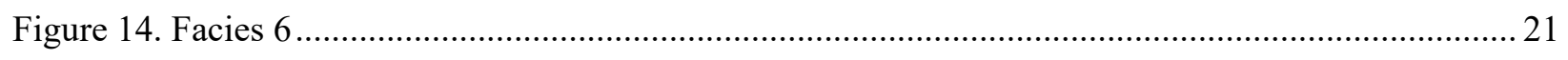

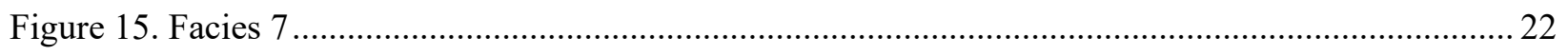

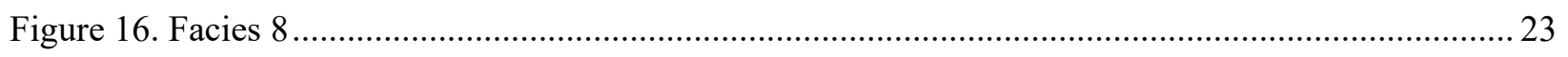

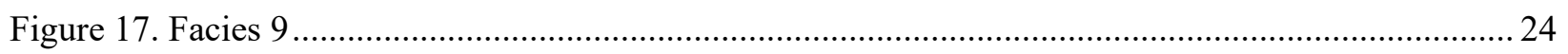

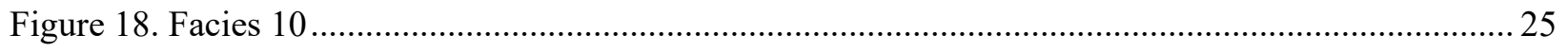

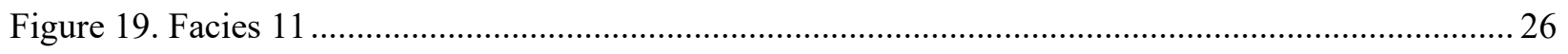

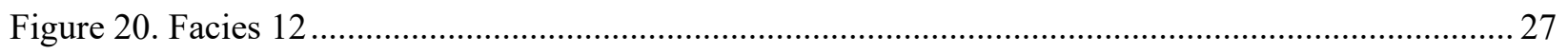

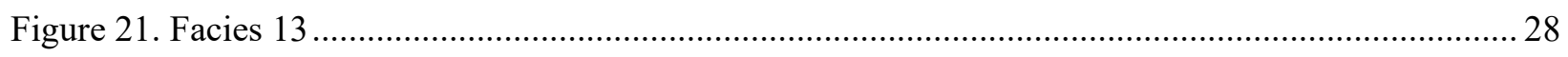

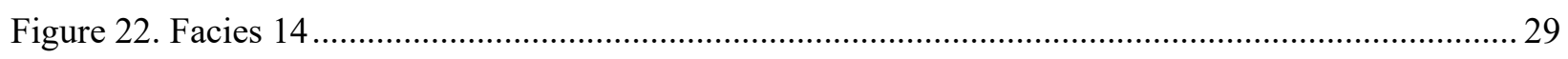

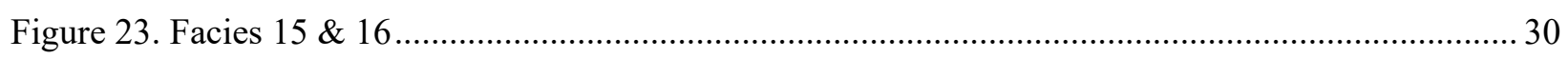

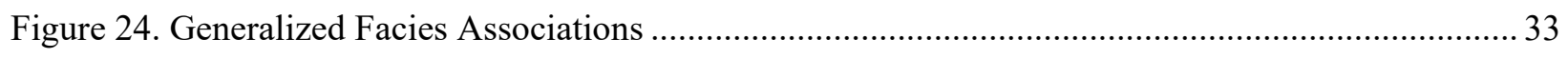

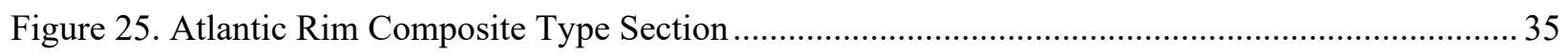


Figure 26. Rock Springs Uplift Composite Type Section............................................................. 36

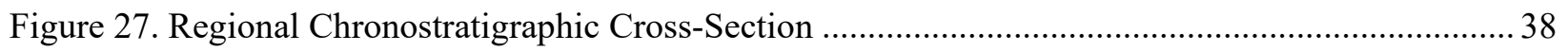

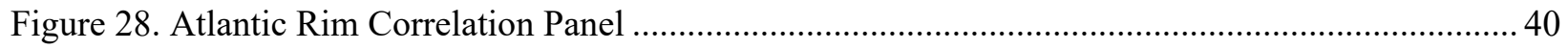

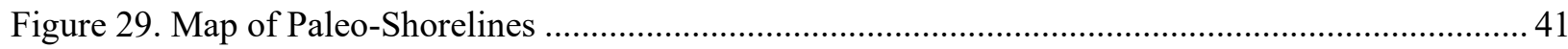

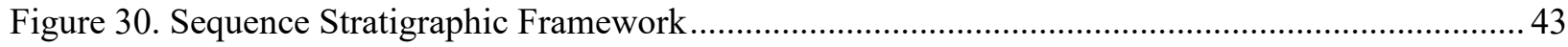

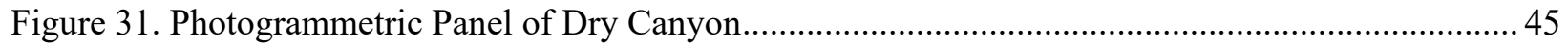

Figure 32. Facies Relationships of the Rock Springs Uplift ............................................................... 46

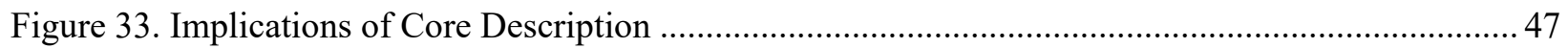

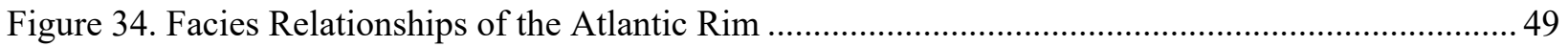

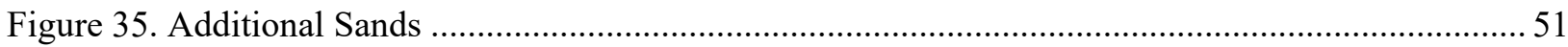




\section{Introduction}

The aim of this research was to build a predictive model of lateral and temporal facies transitions and associated reservoir character within the Almond Formation along the Cherokee Arch (Figure 1). While a considerable amount of research has been conducted on the eastern edge of the study area along the Rock Springs Uplift (Swift, 1968; Roehler, 1990; Martinsen et al., 1999; Schatzinger \& Tomutsa, 1999; Sturm et al., 2001; Tobin et al., 2010; Lopez, 2014), this study adds new information from outcrop and core from the east side of the basin, with the goal of building a more regional sequence stratigraphic framework across the Cherokee Arch. Accurate characterization of these datasets paired with subsurface correlations are useful in understanding the nature of the self-sourced petroleum system in the Almond, along this Laramide structure. Geometry, distribution, and connectivity of marginal-marine sandstones are key to understanding reservoir character.

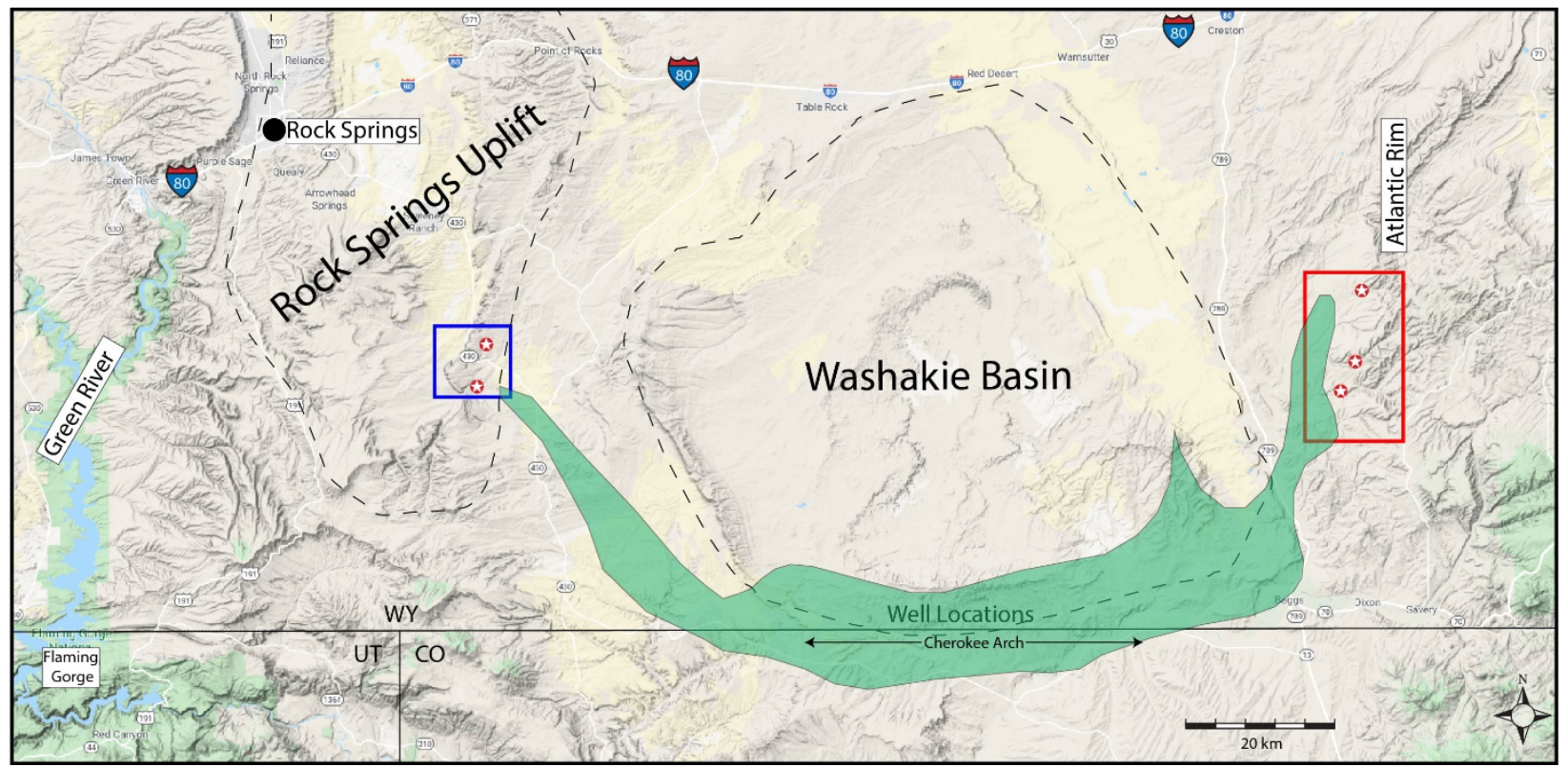

Figure 1. Regional map showing the geographic extent of the study area. Field localities are shown in the blue box (Rock Springs Uplift) and the red box (Atlantic Rim) indicated by red stars. The green polygon shows the spatial extent of subsurface data. 
The Cherokee Arch marks the southern margin of the Washakie Basin and the fold axis is roughly perpendicular to the paleoshoreline of the CIS. Almond strata are exposed at either end of the arch, which is oriented E-W and spans the distance between the Rock Springs and Rawlins uplifts (Figure 2). Three field localities were chosen on the east side of the basin as well as one field locality on the west near the Rock Springs Uplift.

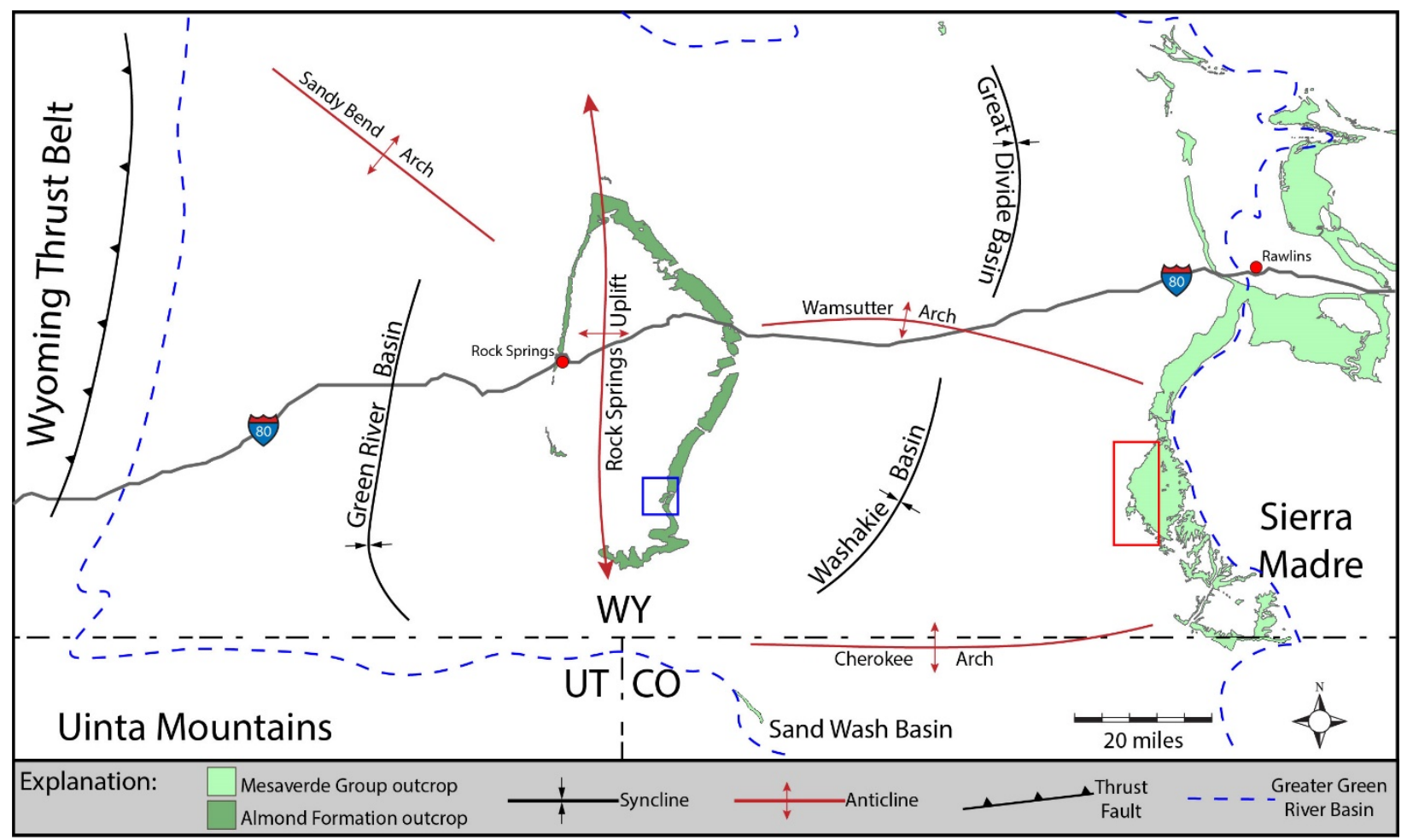

Figure 2. Regional map showing structural relationships to outcrop in the study area. Field localities are shown by the boxes and approximate location of structural features are described with classic structural notation. The blue dotted line shows the extent of the Greater Green River Basin that houses the sub-basins within the scope of the project. Both Sevier- and Laramide-aged features are displayed. 
The Cretaceous Almond Formation, located in the Greater Green River Basin, records the transgressive phase of the of the Mesaverde Group (Figure 3), which was the last major clastic wedge that prograded from the Sevier Orogeny eastward into the Cretaceous Interior Seaway (CIS). As the Mesaverde Group clastic wedge encroached eastward into the Washakie Basin, it deposited coastal plain sandstones and basinward correlative marginal-marine sandstones that have been shown to be prolific oil and gas reservoirs. Hydrocarbon production has been successful through the years along and adjacent to the Wamsutter Arch (Kovach et al., 2003). Previous research has focused in this area as well, both leading to and resulting from exploration along this structural trend. While many wells have been drilled along the southern Cherokee Arch, a similar level of success has not been duplicated. To fully understand this disparity in hydrocarbon production requires extending our understanding of lateral facies changes and sequence stratigraphic architecture away from areas that have been previously studied.

(a)

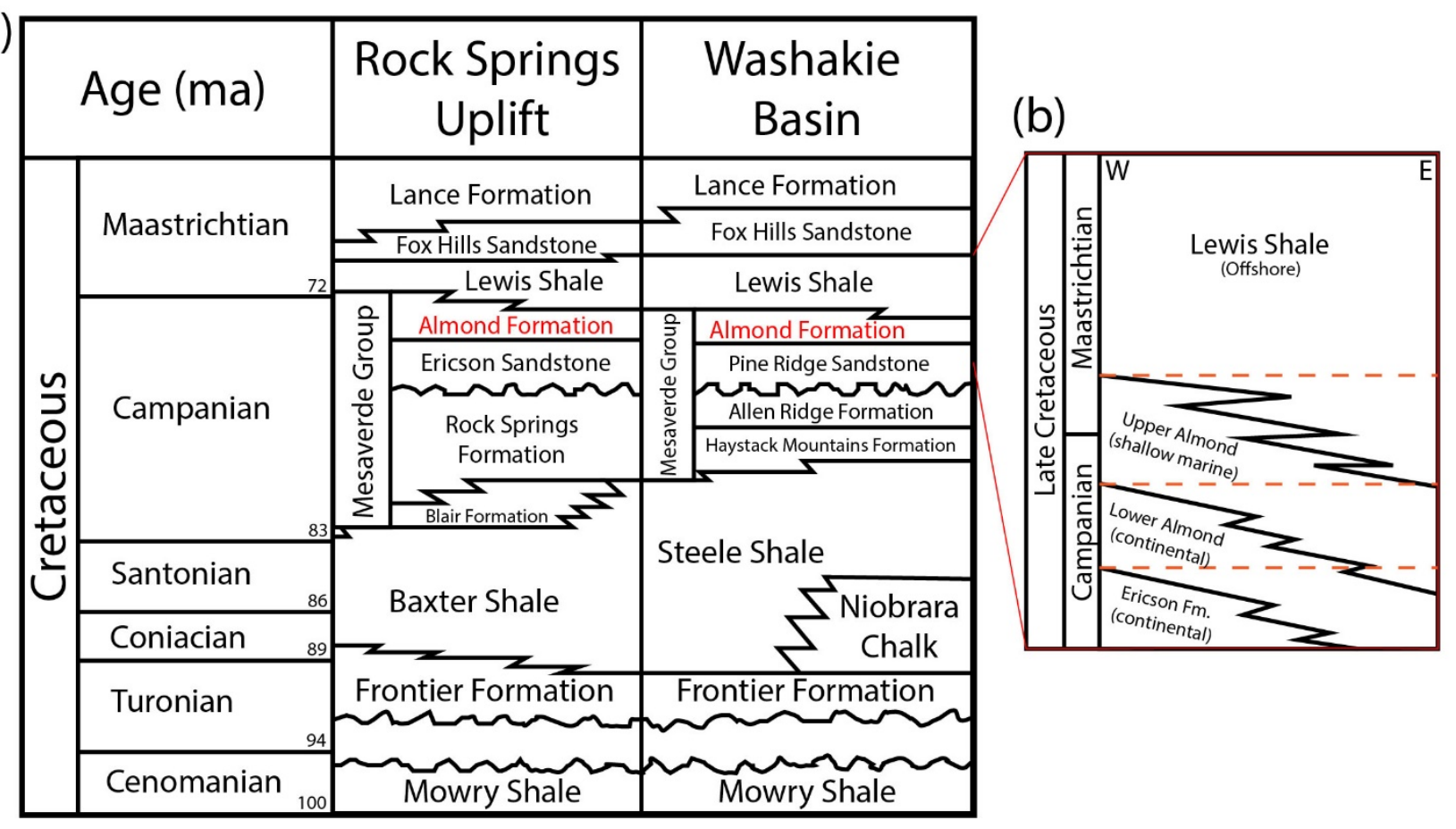

Figure 3. (a) Generalized stratigraphic column (not to scale) of Cretaceous units from the Rock Springs Uplift across the Washakie Basin. The focus of the study is outlined in red (Modified from Mei et al., 2018). (b) Stratigraphic breakout (not to scale) of the upper and lower Almond Formations. (Modified from Kieft et al., 2011) 


\section{Background}

\section{Geologic Setting}

Almond Formation outcrops are abundant both along the Rock Springs Uplift and on the eastern side of the Washakie Basin on what is known as the Atlantic Rim, located south of Rawlins, Wyoming (Figure 2). The Washakie Basin is a sub-basin of the Greater Green River Basin. It is bounded by the Rock Springs Uplift in the west and by the Rawlins Uplift in the east. It is also bounded by less significant uplifts, the Wamsutter Arch in the north and the Cherokee Arch to the south. The Cretaceous Interior Seaway was an elongate, epicontinental seaway that spanned from the Gulf of Mexico to the Arctic Ocean (Figure 4; Lopez, 2014). It was created by a combination of high eustatic sea-level and flexural subsidence resulting from the Sevier Orogeny, which was active from $\sim 140 \mathrm{Ma}$ to $50 \mathrm{Ma}$ (Armstrong, 1968; Decelles, 1994; Lopez, 2014). Thin-skinned tectonics of the Sevier Orogeny not only provided a major sediment source to the study area but also caused a foreland basin to develop where large amounts of sediment could accumulate. Subsequent sub-basin compartmentalization began as thickskinned, basement-cored uplifts of the Laramide Orogeny created largely asymmetric basins within the greater Western Interior Seaway Basin (Armstrong, 1968; DeCelles, 2004; Lopez, 2014). The Washakie Basin was formed as a result of Laramide uplift with most of the structural movement occurring in the early Tertiary, although evidence for movement can be found during deposition of the Ericson Sandstone which predates the Almond Formation (Burch, 1997; Leary et al., 2015). 


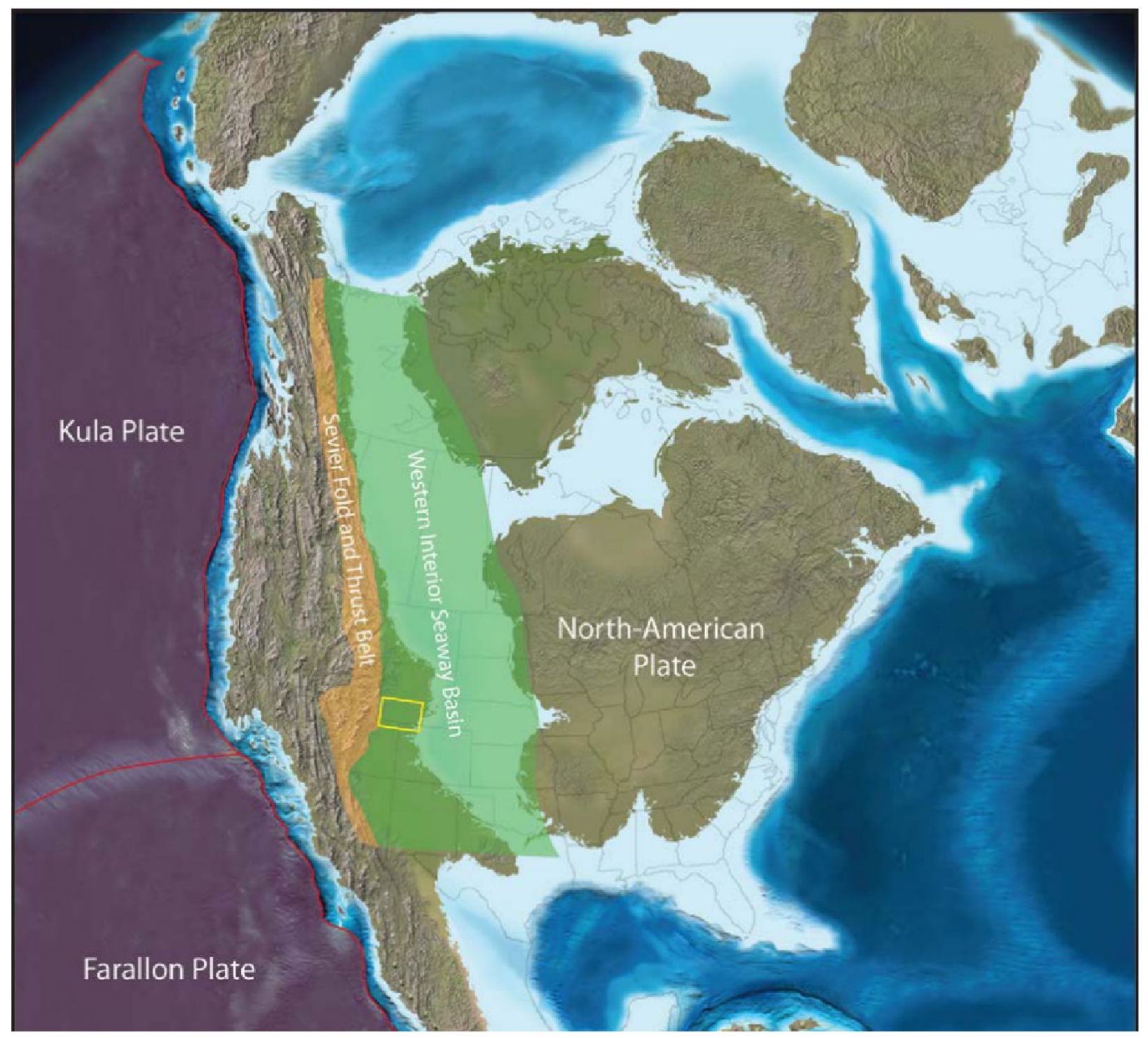

Figure 4. Paleogeographic map showing encroachment of the Cretaceous Interior Seaway during the Maastrichtian while the Sevier fold and thrust belt to the west was active (Lopez, 2014; Blakey, 2014) 


\section{Stratigraphy}

The late Cretaceous Almond Formation was deposited during a net-transgressive sequence along the western margin of the Cretaceous Interior Seaway from the late Campanian to the early Maastrichtian (Figure 4; Blakey, 2014). It is the uppermost of four formations that make up the Mesaverde Group and is well studied along the Rock Springs Uplift where outcrops are prolific. The Almond Formation overlies the Canyon Creek Member of the Ericson Sandstone near the Rock Springs Uplift and Pine Ridge Sandstone to the east (Figure 3). The Ericson and its basinward equivalent represent alluvial plain sandstones that share an unconformable contact to the underlying coastal plain and marine Rock Springs/Blair formations to the west and Allen Ridge/Haystack Mountains formations to the east. The Ericson and underlying Mesaverde units collectively represent prograding deposition of alluvial plain to marine facies across the basin.

According to previous research along the Rock Springs Uplift, the Almond Formation is split into two units informally known as the lower and upper units (Figure 3) (Roehler, 1990; Martinsen et al., 1999; Martinsen \& Christensen, 2005). The lower Almond has been interpreted as having been deposited in coastal plain freshwater marshes and swamps (Roehler, 1990). Carbonaceous shale, thin interbedded gray shale, and sandstone with uncommon thin beds of coal can be found in outcrop in the lower Almond. Single-storey fluvial channels can be found interbedded with mud-rich rocks and have sometimes been found to erode into the underlying Canyon Creek Member of the Ericson Sandstone (Martinsen et al., 1999). Coastal plain deposits grade upwards into estuarine and barrier plain deposits followed by the upper Almond shoreface deposits that have been important reservoirs for oil and gas exploration (Lichtner et al., 2017).

The upper Almond near the Rock Springs Uplift contains barrier bar, tidal delta, lagoonal, and shoreface sandstones up to 75 feet thick (Burch \& Cluff, 1998). The barrier bar deposits in the study area are arcuate in shape and have a generally north to northeastward trend (Burch \& Cluff, 1998). These are 
very fine-to medium-grained sandstones that are lenticular in shape and very important reservoirs for oil and gas (Roehler, 1990). These barrier bar sandstones are an indication of longshore currents enclosing what is known as the Rock Springs Embayment (Roehler, 1990). This embayment was deposited under mesotidal conditions which would indicate that tidal influences were amplified within the embayment and perhaps included several inlets with plenty of sediment forming in the ebb- and flood-tidal deltas (Schatzinger \& Tomutsa, 1999). Previous research near the Rock Springs Uplift shows that shoreface sandstones in this area are horizontally continuous along depositional strike, but are not as vertically connected due to pinchouts into up-dip bayfill facies (Kieft et al., 2011).

Upper Almond strata exposed along the Rock Springs Uplift and time-equivalent basinward strata in the eastern side of the basin contain multiple backward-stepping parasequences that transition from prominent shoreface sandstones at the base of western outcrops to marine shales up-section, which grade into the overlying Lewis Shale. Accommodation, sediment supply, tectonics, and climate are all considered to be local and regional controls on stacking patterns throughout the study area (Rudolph et al., 2015). Complete shoreface successions are present in outcrop and the subsurface, prograding from offshore to foreshore facies associations at a parasequences scale. Bioturbation and heterolithic strata are common and helpful indicators of potential tidal energy (Rudolph et al., 2015). Trace fossils are common, including Planolites and Ophiomorpha, and increase in frequency up-section as does the presence of occasional bivalve fossils (Lichtner et al., 2017). The Almond Formation is interbedded with and overlain by the Lewis Shale, marking the final major transgression of the Cretaceous Interior Seaway.

Previous research includes sequence stratigraphic interpretations along the Rock Springs Uplift, hung from a second order maximum flooding surface that will be referred to in this paper as the Lewis MFS (Asquith Datum) (Rudolph et al., 2015). This second order sequence set begins with a sequence boundary at the base of the Ericson Sandstone (Figure 5). Previously interpreted $4^{\text {th }}$ order cycles within the Almond Formation are done using locally collected data along the Rock Springs Uplift and in immediately adjacent wells. Sequence stratigraphic relationships discussed in this paper are observed on a 
regional, basin scale and differ from previous research.

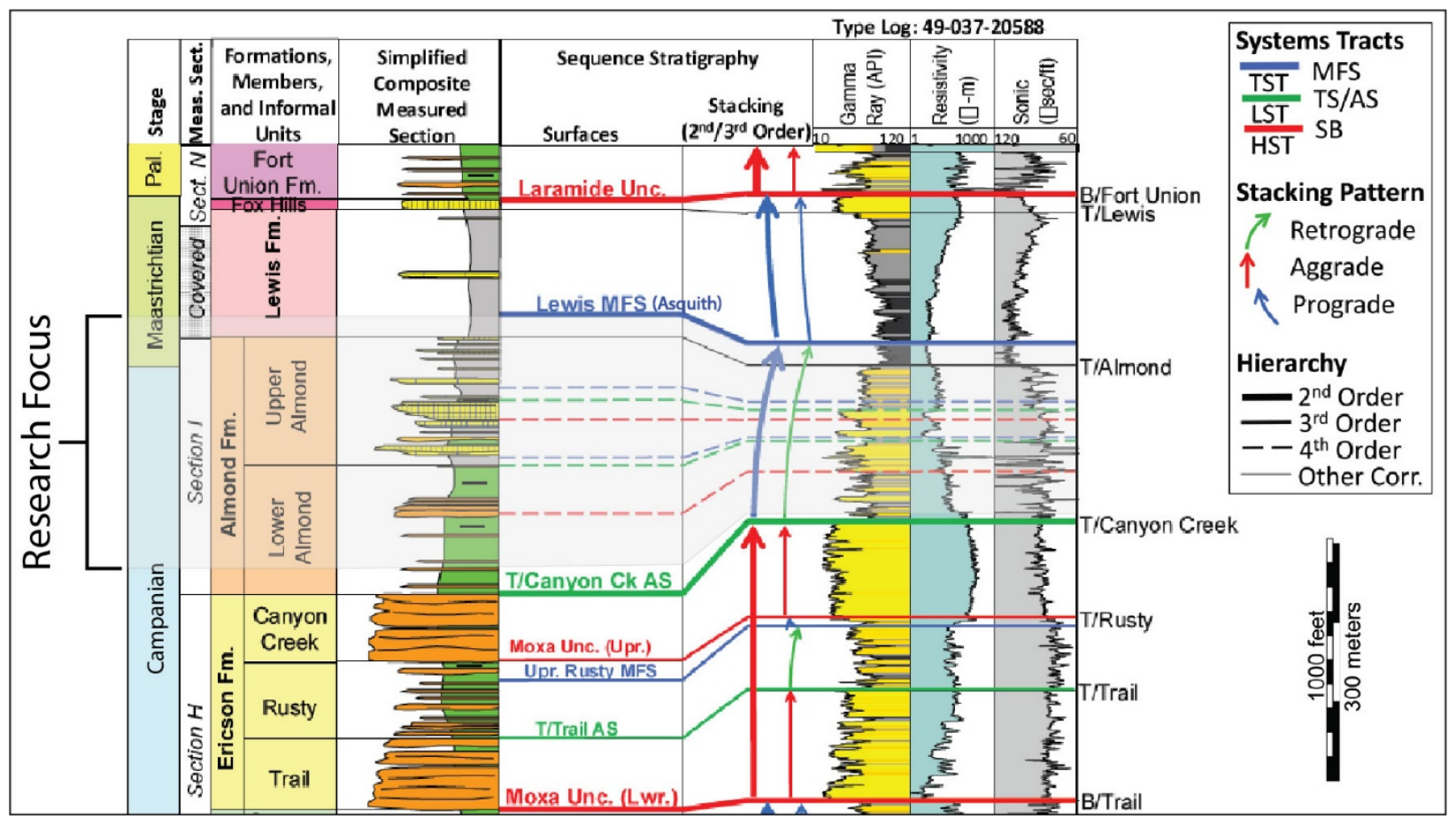

Figure 5. Sequence stratigraphic interpretation from previous research showing major 2nd order cycles and 4th order cycles within the Almond Formation. 4th order cycles are interpreted from local outcrop and well data along the Rock Springs Uplift. (Modified from Rudolph et al., 2015).

\section{Petroleum System}

The Almond petroleum system, which has predominantly produced gas along with some oil over the years, is thought to be sourced by organic rich shales and coal deposits within the Almond Formation. The main source is considered gas-prone, Type III kerogen along with some Type II contribution (Finn \& Johnson, 2005). Evidence shows that while hydrocarbon accumulations are often found in upper Almond sandstones, self-sourced accumulations probably migrated from much deeper in the lower Almond (Mei et al., 2018; Finn \& Johnson, 2005). Although, it is also proposed that perhaps a portion of gas accumulations may be sourced from the Baxter Shale (Finn \& Johnson, 2005). The upper Almond marginal-marine sandstones are the dominant reservoirs given their size and connectivity, although discontinuous lower Almond fluvial sandstones have been known to be productive reservoirs as well (Horn \& Schrooten, 2001). The marine sandstones are fine grained and have measured porosities of less 
than $12 \%$ and permeabilities less than $0.1 \mathrm{md}$, although diagenetic compaction creates variable heterogeneity at depth (Tobin et al., 2010; Rudolph et al., 2015). The Lewis Shale overlying the Almond Formation serves as a seal to vertical migration of gas. Stratigraphic pinchouts as well as structural traps are important to the trapping of hydrocarbons in this region (Finn \& Johnson, 2005). There is also a component of capillary seal and water block serving as trapping mechanisms for continuous gas accumulations in the Almond (Finn \& Johnson, 2005).

\section{Methods}

Measured Sections

Six sections were measured on the east side of the basin in order to better characterize strata, understand facies, and correlate to the subsurface (Figure 6). All of these measured sections are predominantly lower Almond equivalent facies with the transition into upper Almond shallow-marine facies captured before outcrop disappears. Four of the six sections were measured at Deep Gulch (Figure 6) which is roughly 20 miles northeast of Baggs, Wyoming. Two additional sections (JO Reservoir \& Wild Cow Creek) were measured in an effort to spread data points along depositional strike to the north and south of Deep Gulch. 


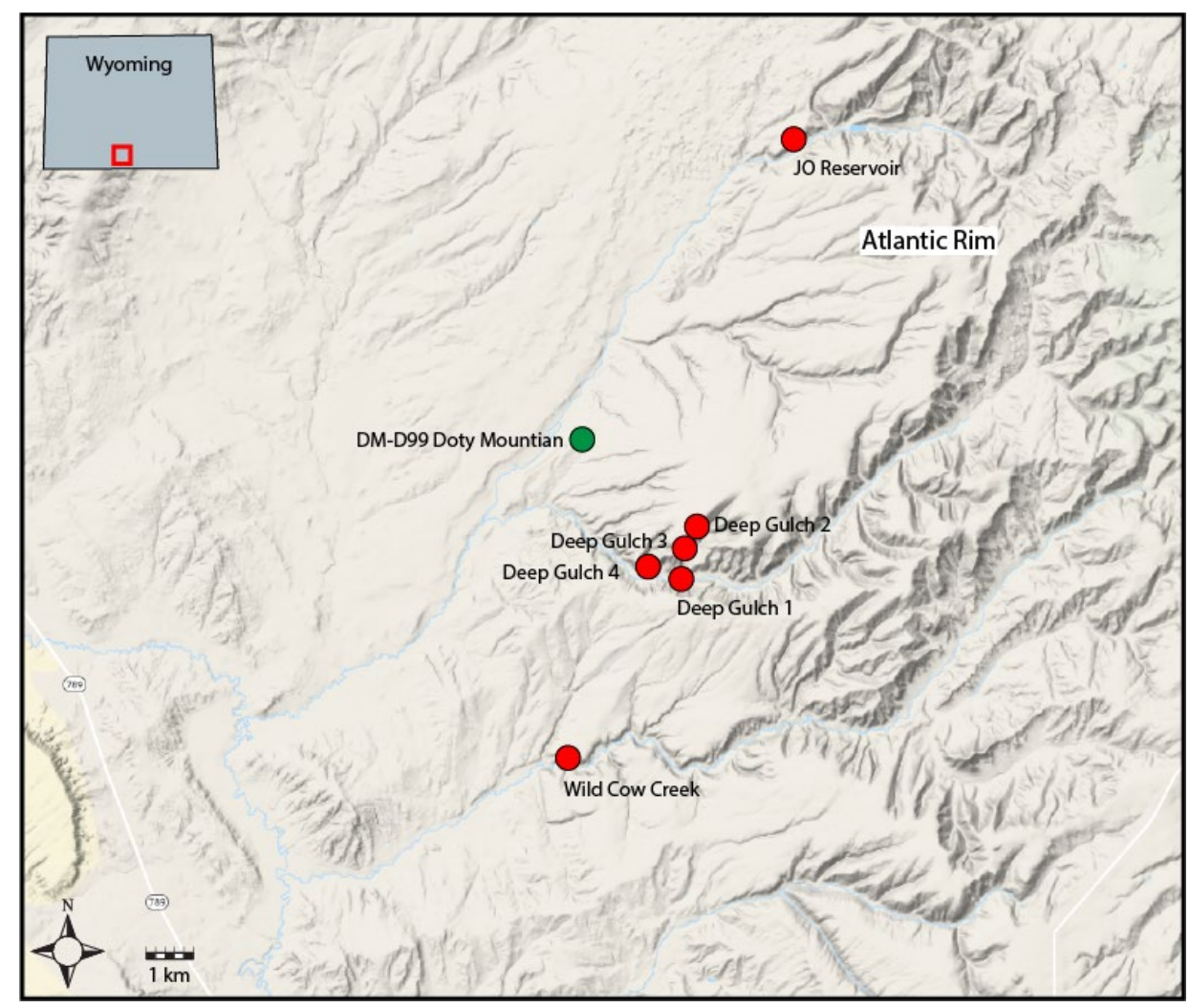

Figure 6. Location map showing the Atlantic Rim Field locality with its six measured sections in red and one core description in green.

In the west field area, two sections (RSU-1 \& 2) were measured north of Ericson Canyon situated between Cooper Ridge and Big Flat Draw (Figure 7). An additional section (RSU-3) was measured near Dry Canyon, where cliff-forming Almond strata can be seen in contact with overlying Lewis strata. These sections were measured to enhance understanding of facies to the west side of the basin and their corresponding interpreted depositional environment as close to Cherokee Ridge as possible. These sections were found to agree with a myriad of work that has already been done near the Rock Springs Uplift, but add necessary context to subsurface analysis. 


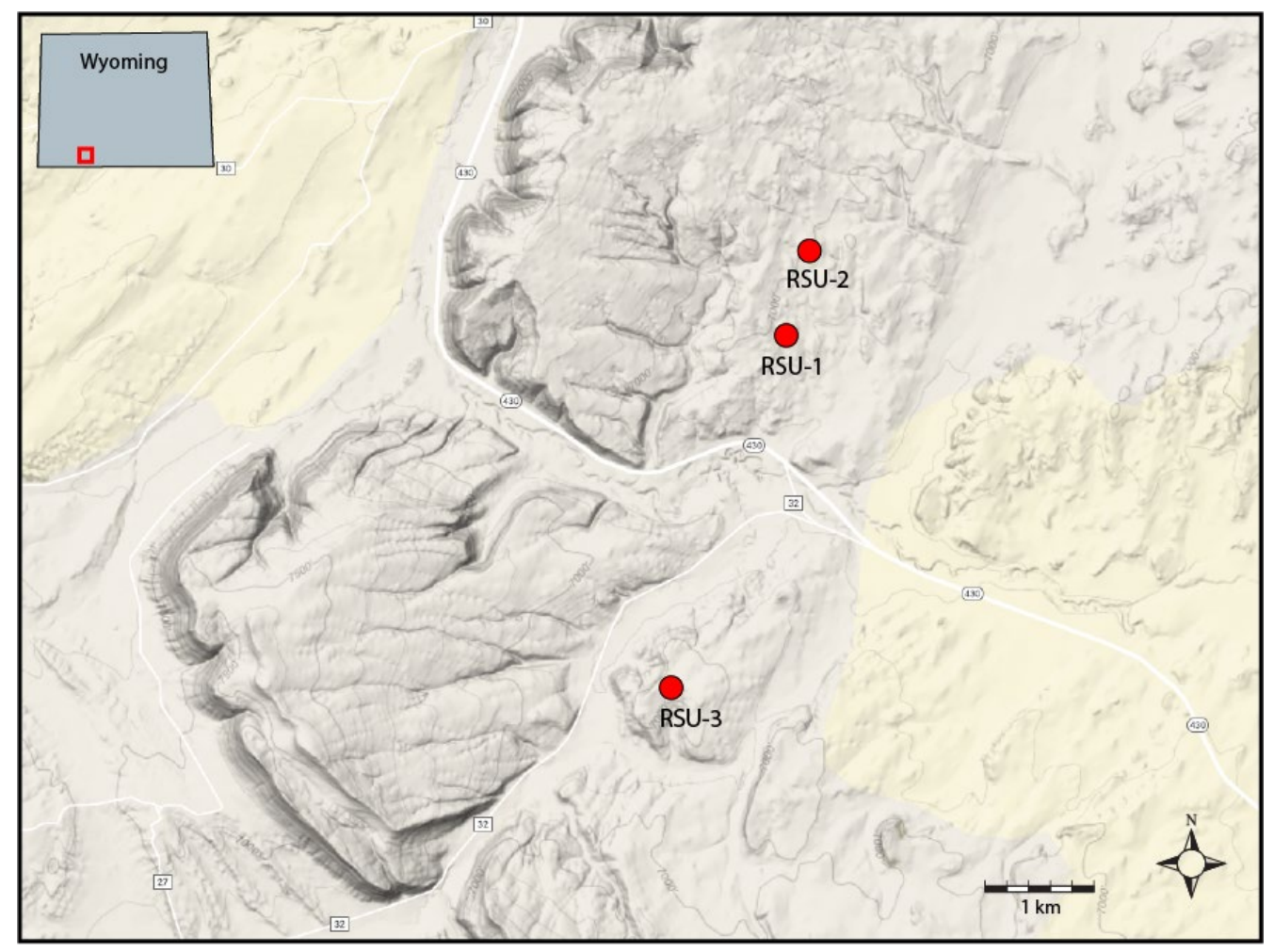

Figure 7. Location map showing the Rock Springs Uplift field locality with its three measured sections shown in red.

All sections were measured with a Jacob's Staff and where possible, included the uppermost section of the Canyon Creek Member of the Ericson Sandstone in the west or the lithostratigraphic equivalent, Pine Ridge Sandstone to the east. Each section was measured and described with a focus on grain-size variability, sedimentary structures, facies associations, bioturbation, and detrital carbonaceous input.

In order to apply data gathered from measured sections in the east to subsurface datasets, a scintillometer (RS-230 BGO Super-SOEC Gamma-Ray Scintillometer) was used on Deep Gulch \#3. Measurements were taken at a half meter interval for sandstone and every meter for shale or mudstones. Each measurement was taken for a duration of 30 seconds and readings for uranium, thorium, and potassium radioactivity were recorded as well as a total composite. A pseudo-gamma ray curve was then 
created using the values collected from outcrop and then corrected to API GR using the following equation:

$$
(19.6 * K)+(8.1 * U)+(4 * T h)
$$

where $\mathrm{K}$ is potassium, $\mathrm{U}$ is Uranium, and Th is thorium. This curve permitted correlation to subsurface datasets.

\section{Core Description}

Upper Almond stratigraphy is not well-exposed at Atlantic Ridge due to modern erosion, however core near the outcrop fills that data gap and facies have been extrapolated to subsurface data as part of this work. 190 feet of upper Almond core, including part of the Lewis Shale, was described in an effort to tie perceived marine facies found in well logs, but not in outcrop. This core (DM-D99 Doty Mountain) is located just north of the Deep Gulch measured sections and was described with particular focus on the nature, quantity, and stacking patterns of marine parasequences (Figure 6). In addition, key sedimentary characteristics were noted including grain-size variability, sedimentary structures, facies associations, bioturbation, and carbonaceous input.

\section{Photogrammetry}

Virtual outcrops were created using Agisoft Photoscan software (Figure 8). Photos from both field sites (east and west side of the basin) were gathered using DJI Phantom series drones. Models were constructed such that spatial analysis of stacking patterns and lateral facies changes could be performed using measured section data obtained in the field. This process was instrumental in developing hypotheses on potential depositional environments for sedimentation at the east side of the basin as the CIS transgressed across the field area. 


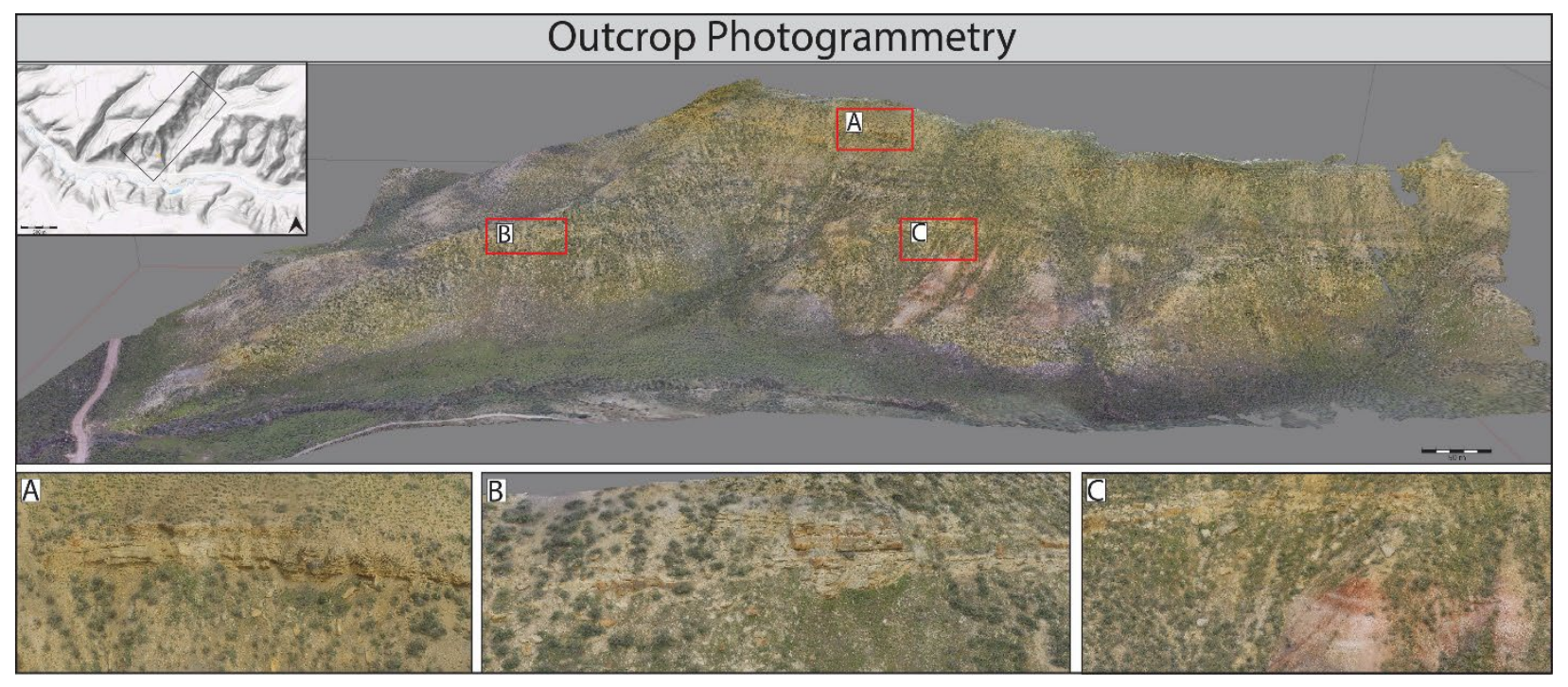

Figure 8. Photogrammetric panel of Deep Gulch field locality in the Atlantic Rim to the east of the Washakie Basin. Model allows for spatial analysis of stacking patterns and lateral facies changes in short distances. Measured sections Deep Gulch 1-3 are numbered on the image. Stacking patterns and facies changes; (A) Marine, (B) Distributary (C) Coastal Plain.

\section{Thin Sections}

Hand samples of perceived reservoir sandstones were obtained and sent to Wagner Petrographic for thin section preparation. Each thin section was prepared in standard dimensions $(27 \times 46 \mathrm{~mm})$ and impregnated with blue epoxy and stain for calcite. All thin sections were qualitatively analyzed to ascertain maturity and composition to aid facies descriptions.

\section{Subsurface Data}

Well logs collected from publicly available archives were used to correlate marine sandstones using chronostratigraphic principles in an effort to understand potential reservoir character and connectivity away from outcrop and into the basin. A total of 71 wells stretching from the southeastern edge of the Rock Springs Uplift to the southern edge of the Atlantic Rim, covering the full length of the Cherokee Arch, were used. Gamma ray, resistivity, and bulk density logs were used to correlate major stratigraphic packages across the Cherokee Arch and identify spatial facies changes. A maximum flooding surface was used as a chronostratigraphic datum from which to hang the logs. This surface is known historically as the Lewis MFS (Asquith Datum) and can be found in the subsurface by locating a distinctively high gamma ray value on gamma ray curves (Mayorga-Gonzalez, 2016; Asquith, 1970; 
Hettinger \& Roberts, 2005). It is located directly above marine Almond sands to the west and within the Lewis Shale to the east. A sequence stratigraphic framework resulted from chronostratigraphic picks.

\section{Results}

Facies Descriptions

Facies were described and then organized into associations based on sedimentary structures, bioturbation, and grain size. Fourteen facies were observed in outcrop and core. All facies described were found on both sides of the basin except oyster beds which were only preserved near the Rock Springs Uplift.

Facies 1: Trough-Cross Stratified Sandstone

One of the most common facies dispersed throughout the lower Almond is high-angle, troughcross stratified sandstones (Figure 9). This facies is composed of very fine to fine grained, sub-angular sand that is well sorted. It is also quartz dominated with very few lithics and some occasional woody fragments. It is observed in every field locality and is always flanked vertically and laterally by laminated carbonaceous shales and heterolithics. Facies 1 varies in thickness from centimeters to several meters and has varying lateral extent from a meter to roughly 30 meters. Separate lensoidal bodies composed of primarily Facies 1 are often vertically amalgamated in the field area, but can be found as isolated, singlestorey bodies as well. This facies is often found to have an orange-colored, chemical weathered rind and can have some carbonate cement based on field observations. Thin sections of this facies show subangular quartz grains with less than $10 \%$ lithics. Bioturbation is mostly absent although some small-scale vertical burrows are found. 
This facies, often expressed in outcrop as isolated, lenticular sandstone bodies, is interpreted to be channelized fluvial distributary sand bodies that are flanked by coastal plain overbank deposits. These sands are likely remnants of a coastal plain environment that brought chiefly quartz grains from the alluvial plain to the west and also incorporated occasional carbonaceous debris.

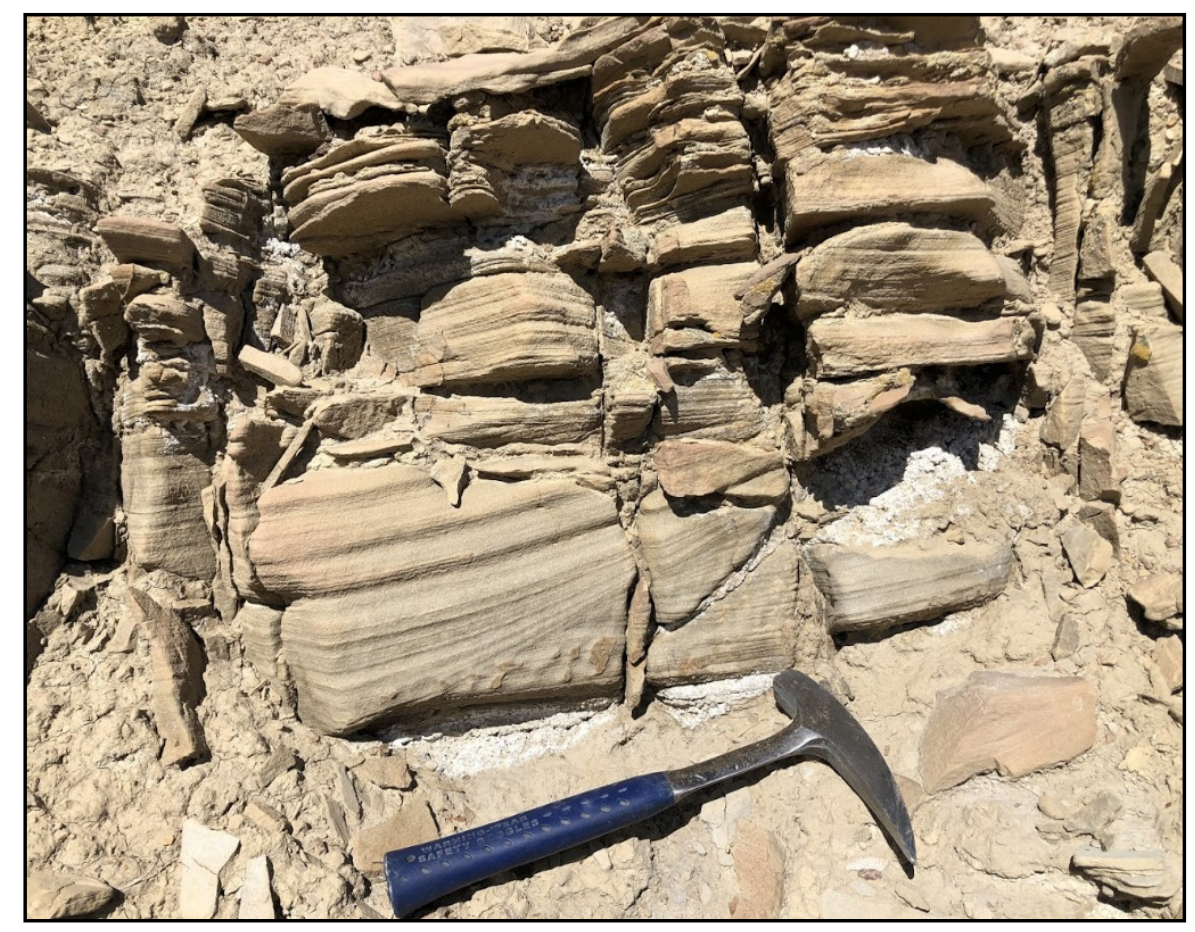

Figure 9. Trough cross-stratified sandstone from lower Almond strata. The scale and angle of troughs can be seen in this image.

Facies 2: Carbonaceous shale

Another ubiquitous facies found on either side of the basin is carbonaceous shale (Figure 10). As expected, it is quite recessive in outcrop but is normally well preserved when sheltered by overlying, resistant sandstone beds. This is typically a very fissile shale with common biological detritus. It is dark grey to black in color and when well-exposed, often contains visually identifiable woody fragments. This facies is almost always paired vertically with silty shales of Facies 3 and can be very laterally continuous. It varies in thickness from a few centimeters to a few meters. 
This facies is interpreted as one constituent of coastal plain overbank deposits as they often flank channel sands and can overlay them as channels avulse laterally. This facies indicates that vegetation was abundant and corroborates understood paleo-climate conditions which indicate temperate conditions (Breithaupt, 1985; Dai et al., 2020).

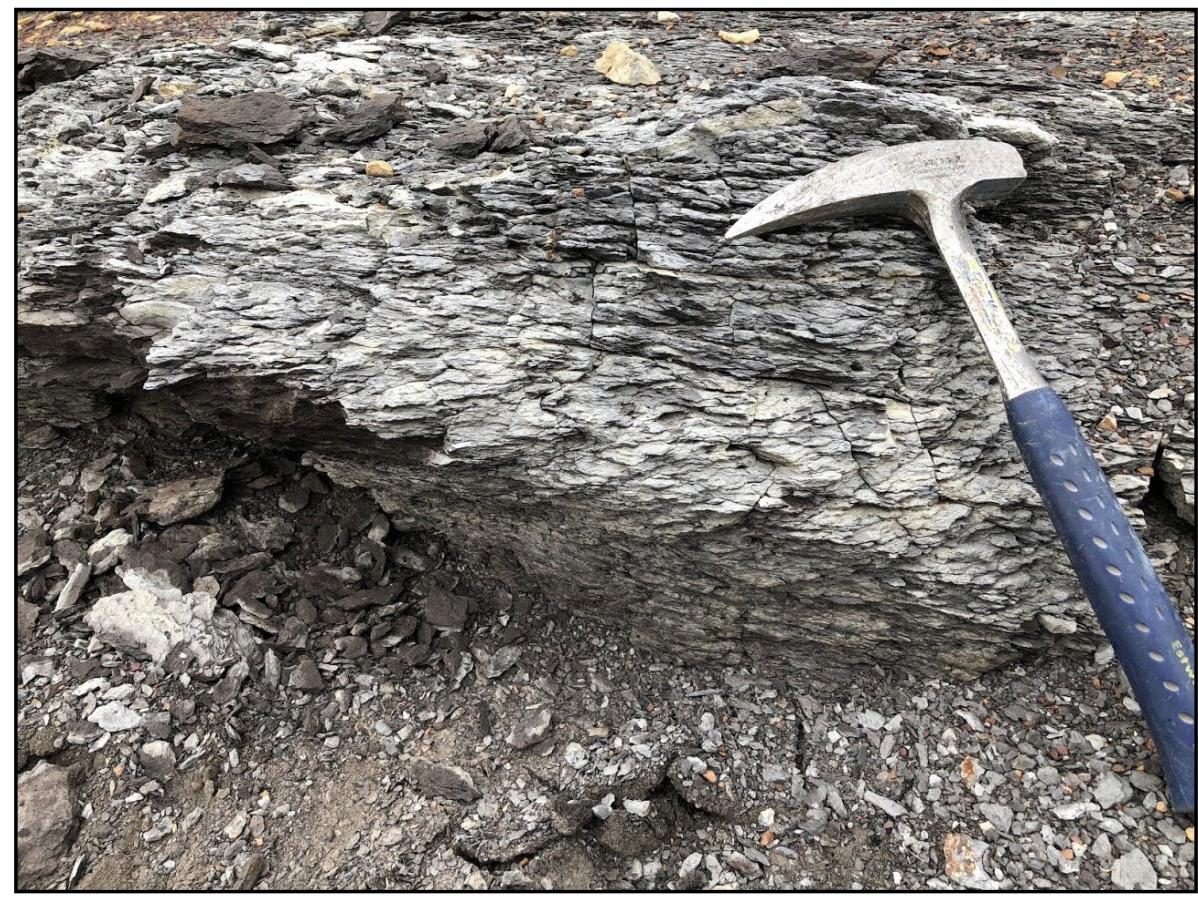

Figure 10. Image showing the common carbonaceous shale facies in the lower Almond.

\section{Facies 3: Brown Fissile Silty-Shale}

Although exposures of this facies are not as abundant, they are consistently found in association with carbonaceous shale and in the lower Almond on both sides of the basin (Figure 11). This facies consists of fine-grained clasts including silt occasionally interbedded with thin sand stringers. Organic detritus is absent except within discrete thin sands. It is rarely over a meter in thickness and is dark brown in color. 
This facies is interpreted to represent fine-grained overbank deposition in floodplain areas adjacent to channels in the coastal plain. These deposits are found in close association with the channel sands of Facies 1 as a result of stream avulsion. Autogenic controls on channelization cause avulsion to occur which allows for facies shifts from overbank deposits to channel sands.

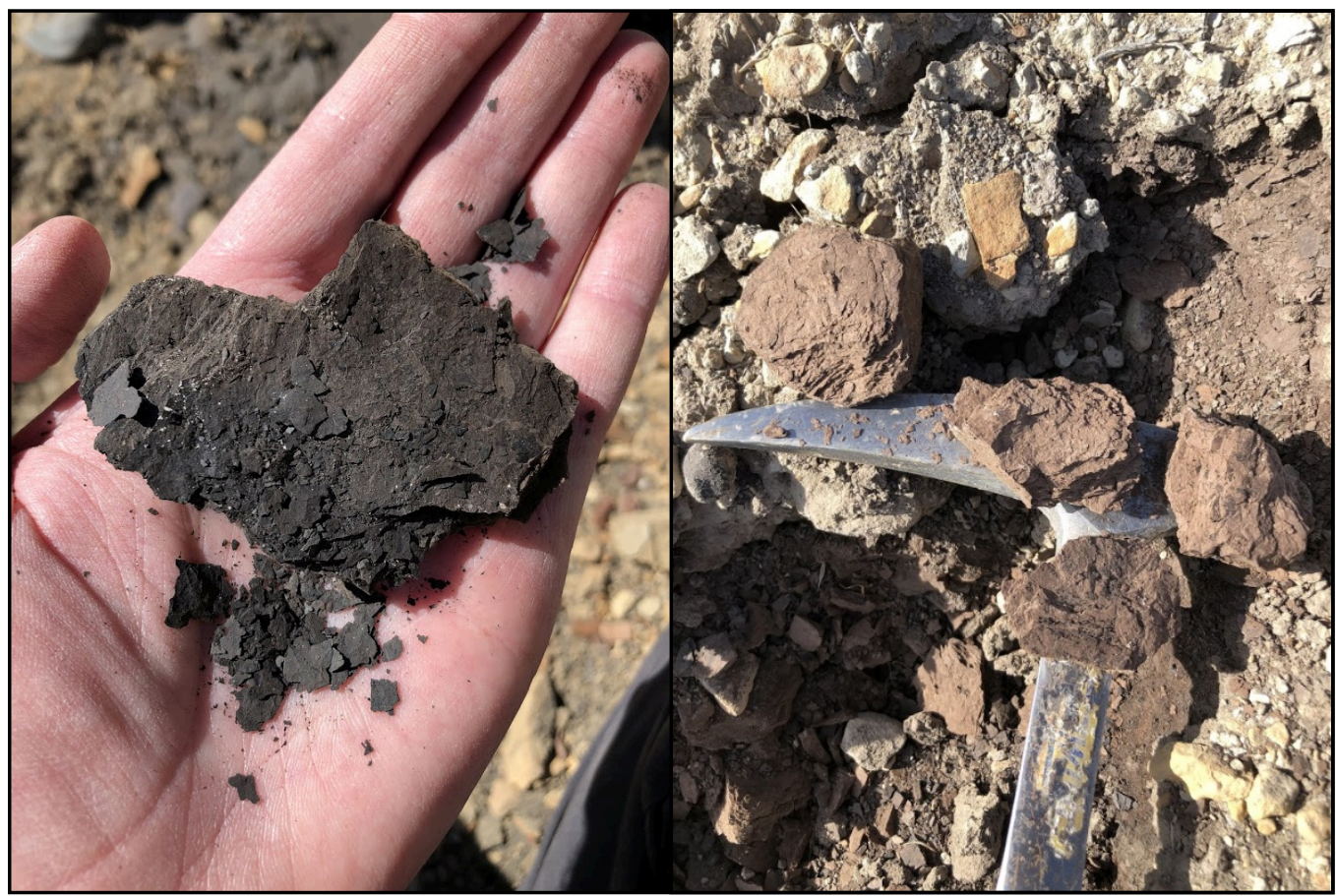

Figure 11. Two images of Facies 3 showing the fissile and flaky nature of the lithology.

Facies 4: Coal

The Almond Formation is known for its coal deposits and it is thought that coal is the principle source for natural gas found in conventional reservoirs (Finn \& Johnson, 2005; Mei et al., 2018). This facies appears on either side of the basin in varying quantities and thickness (Figure 12). It is prevalent in the lower Almond in close proximity to overbank facies, but also is cyclically found on top of parasequences in the upper Almond. Coal deposits can vary from centimeters to several meters in 
thickness throughout the field area and are much thicker and more laterally continuous in the upper Almond.

This facies is interpreted to represent preserved terrestrial organic matter dispersed in a coastal plain depositional setting in interdistributary and overbank swamps. It is also interpreted to represent proximal back-swamps stacked on top of shallow-marine parasequences, but is not always apparent in outcrop. Though much of the upper Almond equivalent is absent in outcrop on the east side of the basin, nearby subsurface data show many flooding surfaces that overlay proximal back swamps.

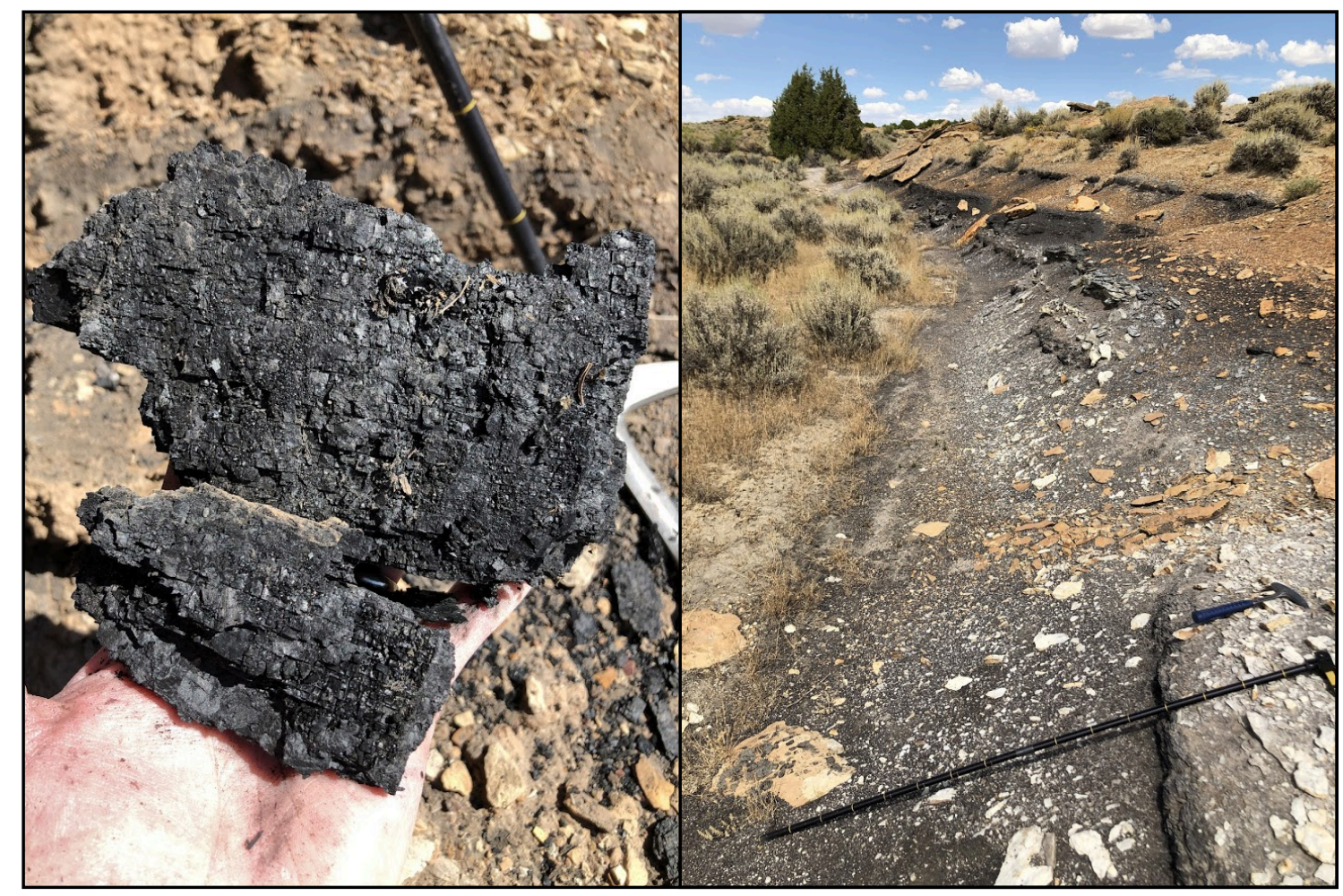

Figure 12. Image to the left shows a close-up of a coal deposit near JO Reservoir. The image to the right shows how thick and sometimes how continuous they can be. The image to the right was taken at the Rock Springs Uplift. 
Facies 5: Heterolithic Trough Cross-Stratified Sandstone

Fluvial signatures are recorded throughout the lower Almond and vary from small, single-channel sands to multi-storey distributary deposits. This facies is fluvial in nature but more complex in sedimentary structure and architecture than facies 1 (Figure 13). These outcrops are meters in thickness and tend to be much more laterally continuous than Facies 1 . Preservation of sedimentary structures include trough-cross and planar cross-stratification with some occasional climbing ripples. Heterolithic strata and well preserved mud rip-ups with some channel lag is common. These outcrops can also exhibit remarkable soft-sediment deformation from ball and pillow to recumbent folds. Grain size is observed to be fine grained and is well sorted with subangular clasts. Wood and plant fragments are absent and preservation of bioturbation is rare.

Based on sedimentary structures and varying texture, this facies demonstrates alternating flow regimes that are capable of incorporating fine-grained clasts at times as well as periods of high sediment flux. This leads to heterolithic grain distribution and pervasive soft-sediment deformation. These outcrops are generally found up-section from Facies 1 and may coincide with a sustained period of progradational pulses before overall transgression occurred. This facies is interpreted to represent channelized and other associated deltaic deposits that result from large amounts of sediment flux and varying grain size. 


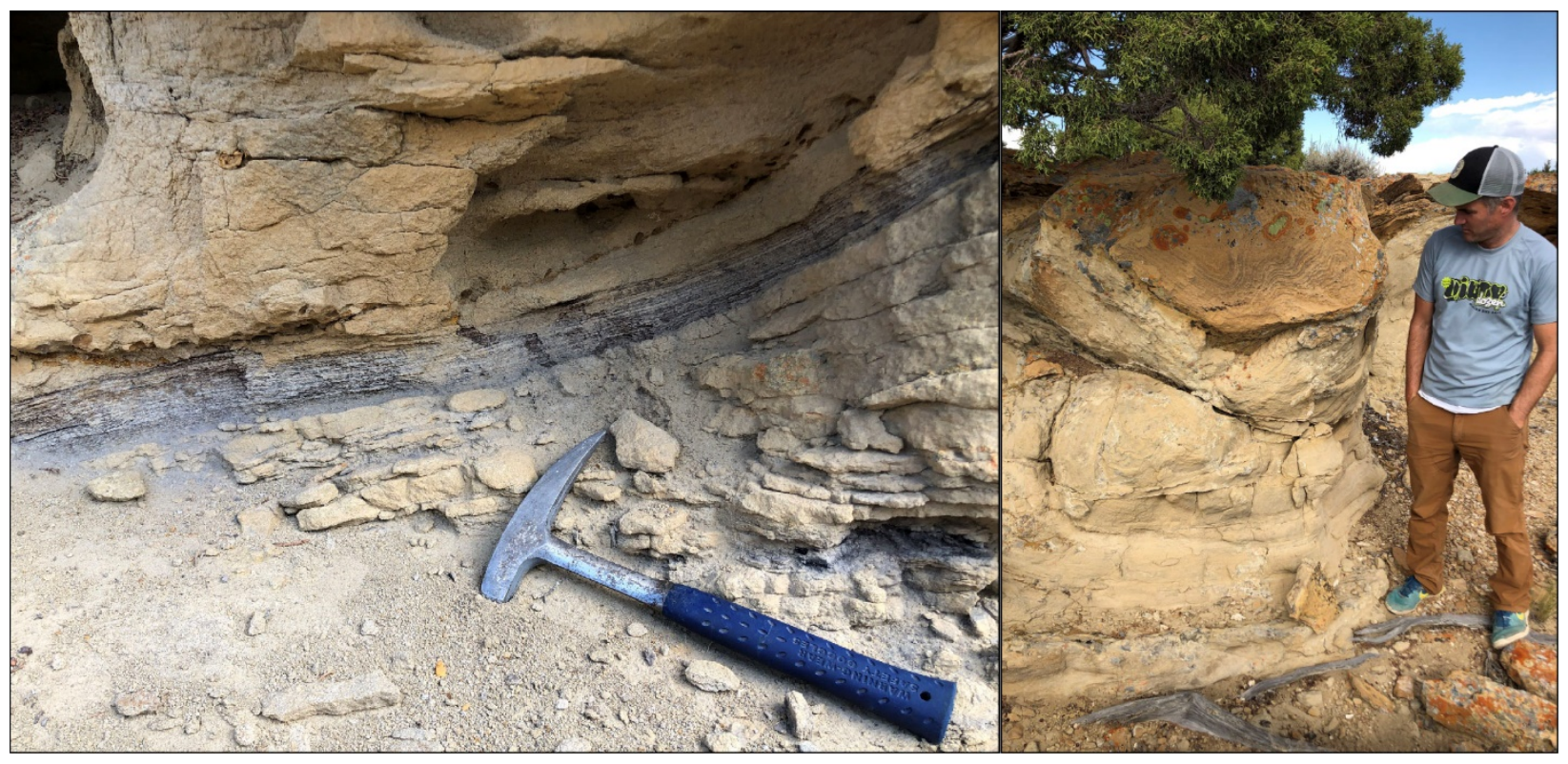

Figure 13. Image to the left demonstrating heterolithic deposition as well as channel lag. Image to the right shows facies also exhibited a great deal of soft sediment deformation.

Facies 6: Ripple-Laminated Silty Sandstone

Ripple lamination is a sedimentary structure that can be found in numerous outcrops in both lower and upper Almond strata in some small degree. However, these outcrops define facies that almost exclusively feature oscillatory ripple lamination throughout with some planar lamination as well (Figure 14). This facies is found in lower Almond strata and is often flanked and overlain by fluvial and overbank deposits (Facies $2 \& 3$ ). Exposures of this facies can be roughly a meter to several meters thick, but are limited in lateral extent and are poorly exposed due to the interbedded fine grains. Strata are commonly heavily bioturbated and are often heterolithic. However, bioturbation is indistinguishable, but destroys bedding where abundant. Outcrop is often highly oxidized and poorly exposed due to the grain distribution. Clasts are very fine-to-fine grained sand with interbedded silt.

It is interpreted that this facies developed under non-marine, shallow-water conditions where ripples could form without displacing much sediment. Rapid sedimentation led to rapid burial and limited dewatering of sediments, resulting in non-dewatering structures. This facies is interpreted to represent a 
very shallow, nearshore, and flooded environment which may incorporate bioturbation found in brackish conditions.

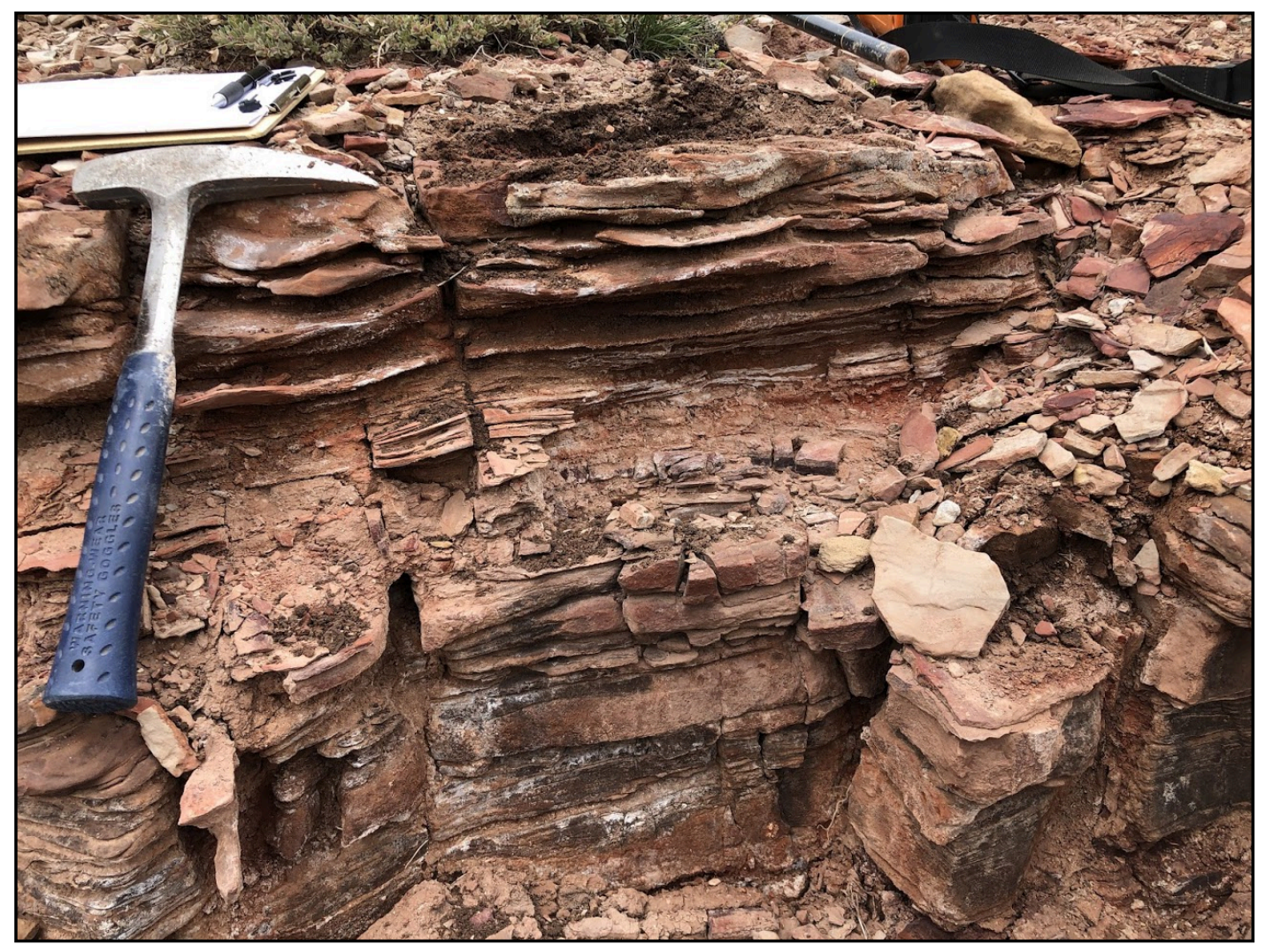

Figure 14. Outcrop image showing oxidized wave-rippled, interbedded sand and siltstone.

Facies 7: Planar-Laminated Sandstone

While trough cross stratified sandstones dominate a great deal of the lower Almond, a more infrequent, but coupled facies was observed. This facies is composed of very fine-to-fine grained sand that is well sorted (Figure 15). It varies in lateral extent, but can be found to extend as far as 30 meters. The only sedimentary structure observed in this facies is planar laminations. Small-scale vertical burrows are the other distinctive feature in these outcrops. 
This facies is interpreted to represent crevasse splays deposited into the floodplain from stream channels. One such splay was found to be paired with a channel deposit on the east side of the basin giving direct evidence for such an interpretation.

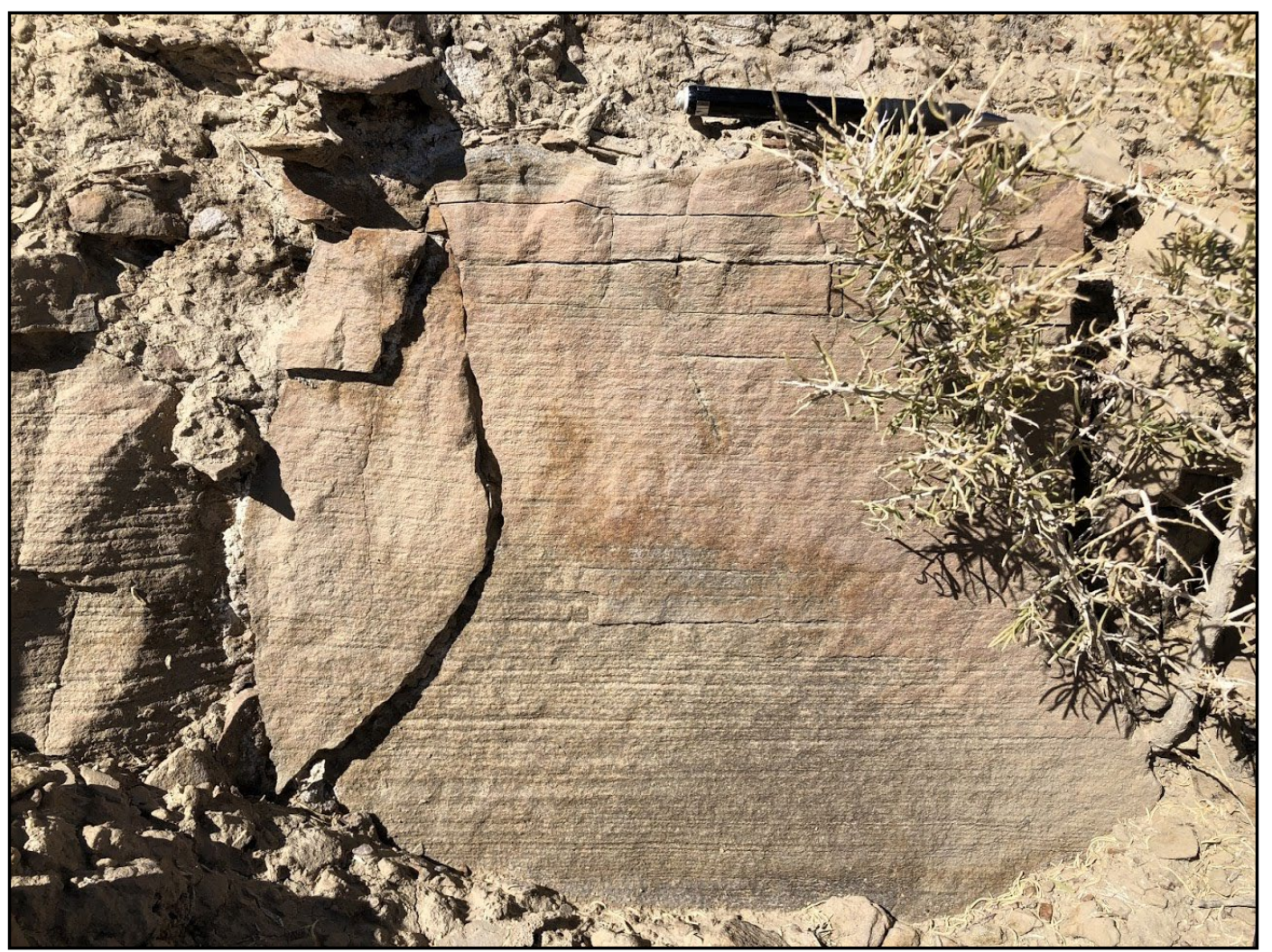

Figure 15. Planar laminated sandstone.

Facies 8: Small-Scale Trough-Cross Stratified Sandstone w/ Thick Mud Drapes

A shorter section of preserved Almond strata was found both at JO Reservoir and Wild Cow Creek (Figure 6). A rather thick section of small-scale trough cross-stratified sandstone with substantial mud drapes was described and appears to be exclusive to the JO reservoir measured section (Figure 16). This facies is composed of very fine sandstone with small-scale troughs ( $\sim 10 \mathrm{~cm}$ wide) that are either filled with fine-grained mud drapes or eroded cavities where drapes had been. While bioturbation is present throughout, preserved burrows are not diverse. Outcrops are roughly three meters thick and fairly continuous laterally. 
This facies is interpreted to represent differing flow regimes in the same environment depositing predominantly sand while at times delivering finer-grained clasts. The drapes represent a minor component of the overall outcrop. While a tidal signature could be interpreted here, evidence is inconclusive since there are no indicators of an opposing flow direction.

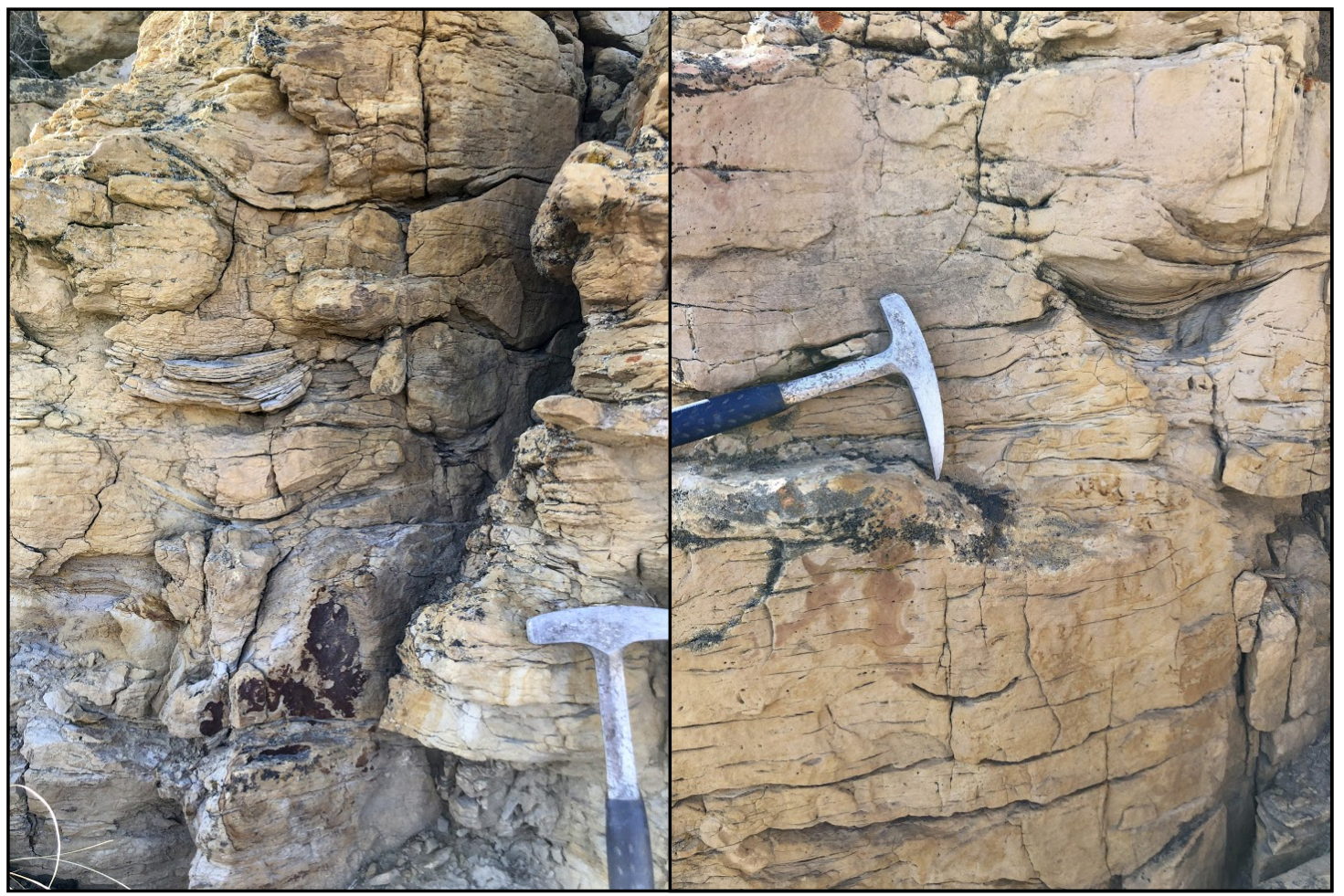

Figure 16. Images of outcrop at JO Reservoir that are full of concave mud drapes. In most cases the mud drapes are weathered out. Outcrop includes very small vertical burrows.

Facies 9: Trough-Cross and Ripple-Laminated Sandstone with Bivalves

Almond stacking patterns preserve a transitional facies that is indicative of a brackish environment as the coastal plain freshwater environment shifts to the marine. The Deep Gulch \#1 section preserves this facies (Figure 17). It comprises a very fine grained sand that is primarily trough-cross stratified with large scale troughs (meter scale) and bivalves. Channel fill is also full of oscillatory ripple laminations towards the flanks with some periodic heterolithic sedimentation and bioturbation. Mud ripups are common and show periodic flow regime shifts. Outcrop is prominent and provides structure to the 
ridge while being flanked by overbank deposits on either side. This facies is commonly found in Dry Canyon (RSU-3) also as shell lags are even more prevalent in distributary channels.

This facies is interpreted to represent a distributary channel showing variable salinity. Preserved bivalves found in outcrop are indicative of a shift away from freshwater but not quite fully immersed in the marine environment.

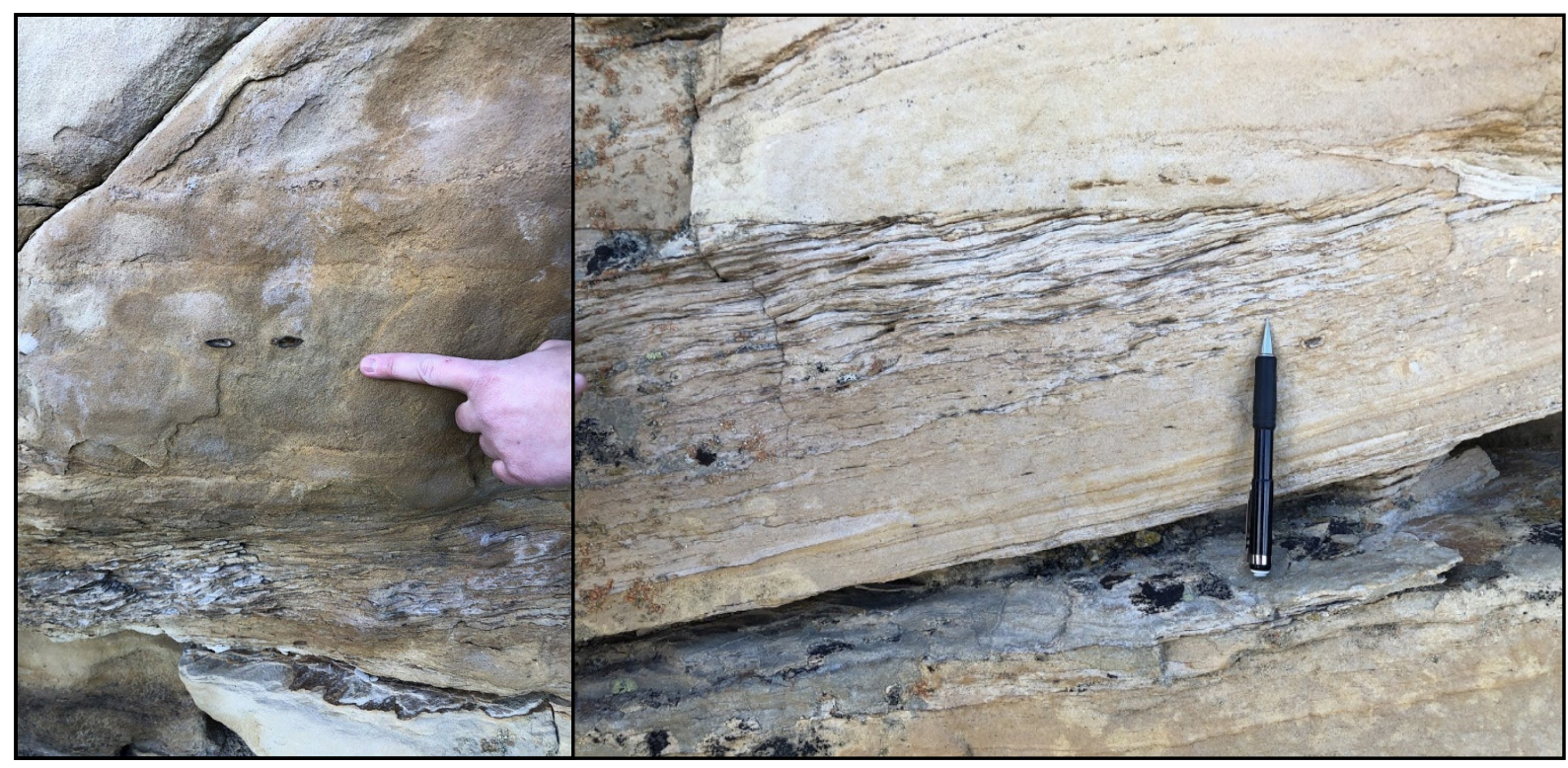

Figure 17. Image on the left shows bivalve fossils in a largely trough cross-stratified sandstone. The image on the right shows oscillatory ripple lamination on the flanks of this channel form.

\section{Facies 10: Oyster Beds}

While beds mainly composed of oysters were not found on the east side of the basin, they were discovered in two of the measured sections from the west side. This facies consists of sandstone containing abundant oysters (Figure 18). This facies can be found in close association with ripple laminated silts, coal, and other woody detritus. This facies shows evidence for an embayment to the north of Hwy 430 (RSU-1 \& 2) that likely produced calmer waters and received input from both marine and freshwater sources. Bayfill sediments are interbedded with oysters and are composed of alternating clast size from clay to sand. This embayment was likely protected by a spit producing calmer water 
sedimentary structures and sedimentation. This facies also is found to completely cover marine sandstones to the south where a more deltaic influence is indicated.

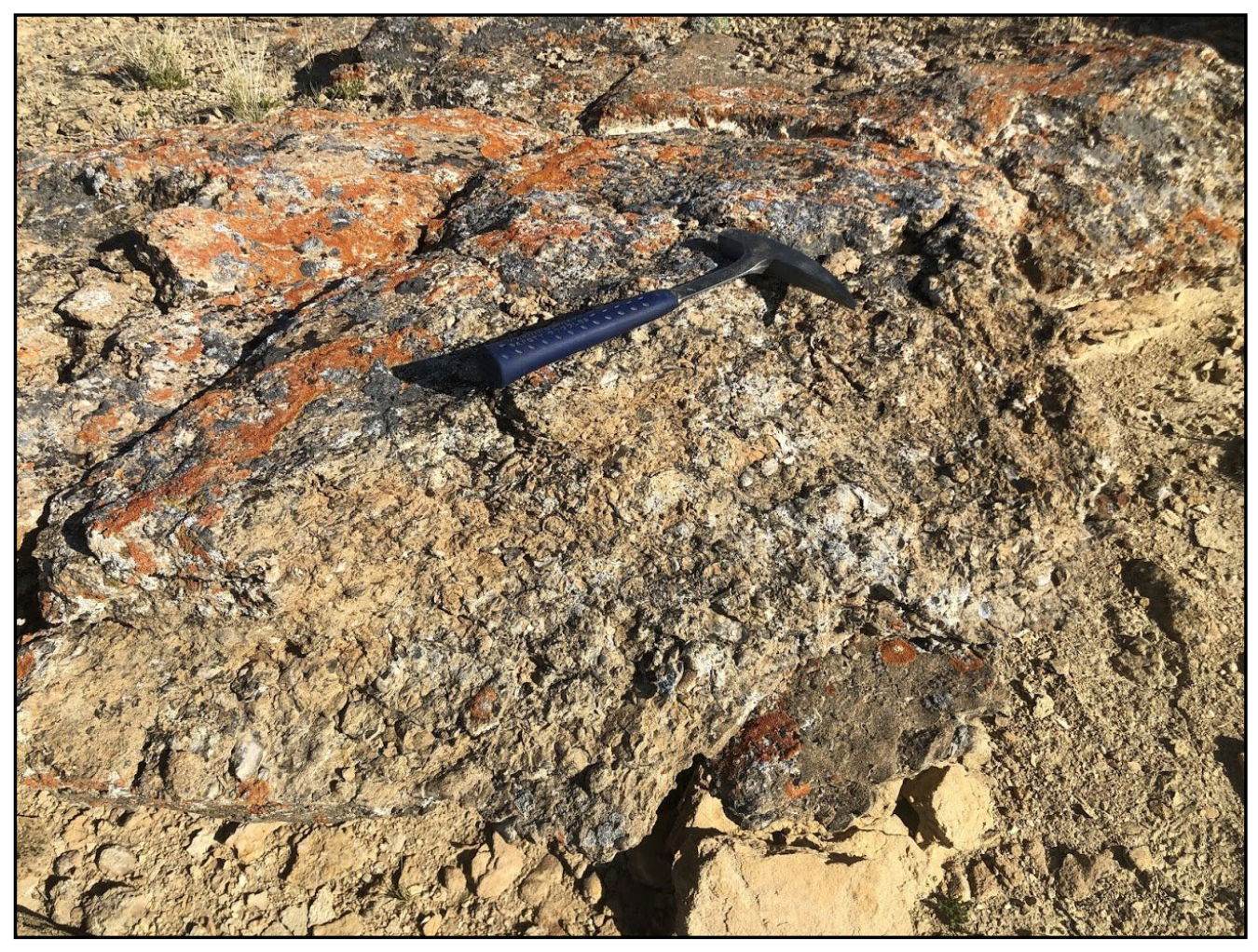

Figure 18. Image shows a predominantly oyster-filled sandstone closely related to fine-grained sediments to the north of Hwy 430.

Facies 11: Hummocky Cross-Stratified Sandstone

This facies is common in outcrops of the upper Almond on the west side of the field area. In contrast, the only occurrence of this facies to the east is where it supports the ridge at Deep Gulch, where it is only a few meters thick (Figure 19). It is composed of very fine-grained sandstone distributed into swales and hummocks. The clasts are well sorted and are typically overlying interbedded silt and sand stringers. Ichnofacies assemblages are diagnostic for this facies. Thalassinoides, Planolites and other horizontal and vertical burrows are common. 
This facies is interpreted to represent deposition in a lower shoreface environment and is commonly associated with Facies 12 and 16, and often has a gradational contact with overlying Facies 12. This facies commonly coarsens up as finer grained shales intertongue with it before becoming dominated by sand.

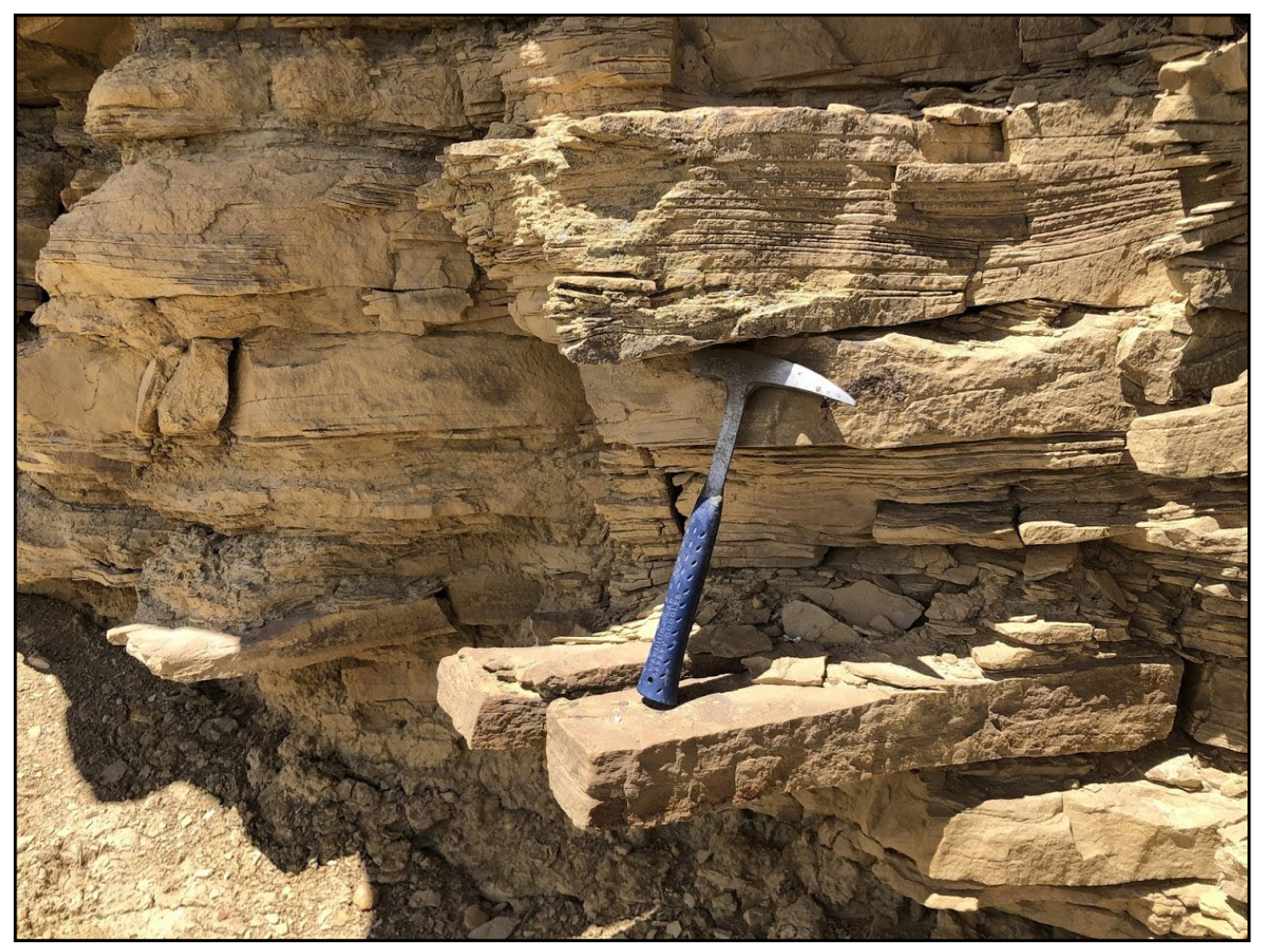

Figure 19. Image showing hummocks and swales at Deep Gulch in a laterally continuous sandstone that holds up the ridge. This image shows a coarsening upward marine succession from offshore fines to lower shoreface sands.

\section{Facies 12: Bioturbated Trough-Cross Stratified Sandstone}

Low angle, trough-cross stratified sandstone with marine bioturbation is often found gradationally overlying facies 11. It is composed of very fine upper-to-fine grained sandstone (Figure 20). Grains are well sorted and often disturbed by Ophiomorpha burrows as well as small-scale troughs and occasional ripple lamination indicative of a consistent higher-energy environment. These beds are very laterally continuous and are just a few meters thick. This facies is interpreted to represent the upper shoreface 
where waves consistently reworked sands. Burrows are from the Skolithos ichnofacies and are predominantly Ophiomorpha and Skolithos traces.

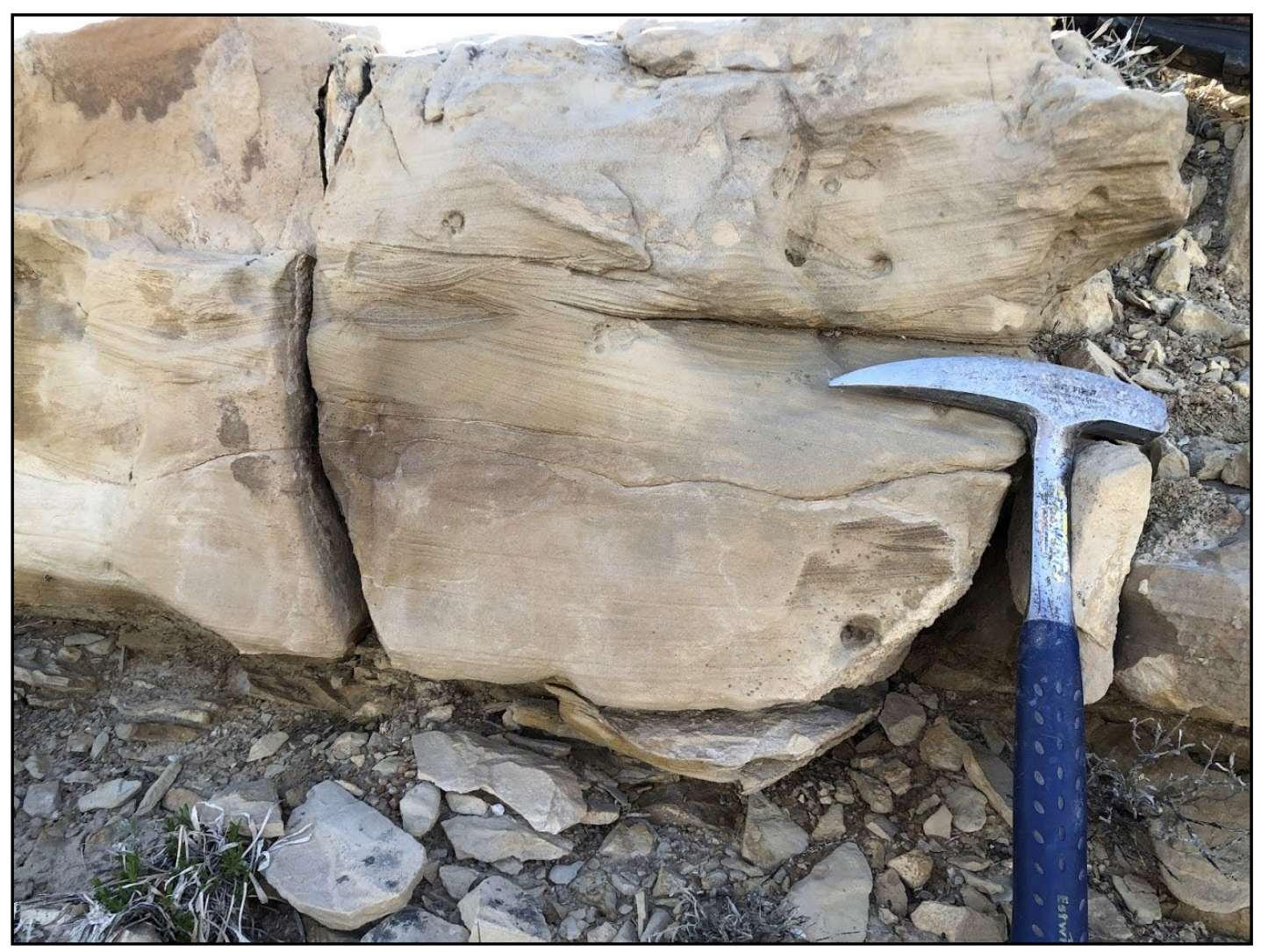

Figure 20. Image shows both trough cross-stratified sandstone with abundant ophiomorpha traces near the top.

Facies 13: Heavily Bioturbated, Ripple-Laminated Sandstone with Roots

A shorter section measured south of Deep Gulch at Wild Cow Creek reveals a facies that has a diverse collection of trace fossils (Figure 21). This facies is exclusive to Wild Cow Creek and its lateral continuity is less than marine outcrops found at Deep Gulch. It is composed of a very fine lower to very fine-grained upper sandstone and shows upward coarsening. It is a few meters thick and contains ripple laminations throughout. Low-amplitude symmetrical ripples and planar lamination are common. Trace fossils consist of Arenicolites, Skolithos, Conichnus, Ophiomorpha, and root structures. Many of these 
traces would suggest a marine environment and the presence of root traces extending downward from the upper contact suggests that there was an exposure surface at the top of this deposit. Based on this, Facies 13 is interpreted to represent deposition in a shallow-marine setting. This facies at the Wild Cow Creek locality, is overlain by what is interpreted as an avulsed distributary channel (Facies 1,9).

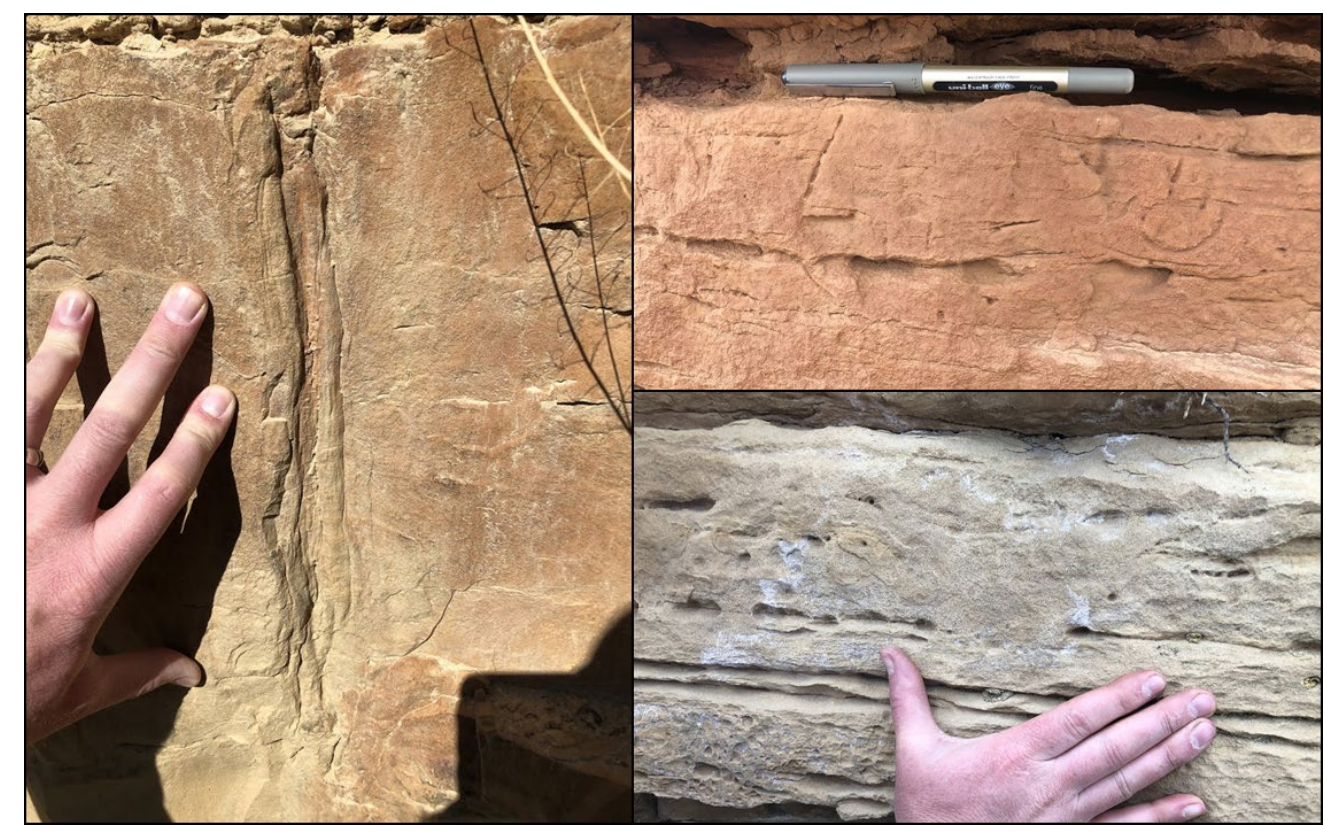

Figure 21. Outcrop photos from Wild Cow Creek. The left image a large root trace at the top of the outcrop. The top right image shows an Arenicolites burrow and the image in the bottom right shows a Chonicnus burrow.

\section{Facies 14: Planar-Laminated Marine Sandstone}

This facies is exclusively found on the west side of the basin in outcrop, but is preserved in core found on the east side (Figure 22). It is composed of fine-grained, well sorted planar-bedded sandstone. This facies is several meters thick, making up a large portion of well exposed marine sandstone that can be seen from a significant distance. This facies is interpreted to represent the foreshore where marine waters leave behind reworked sands in sheet-like deposits. 


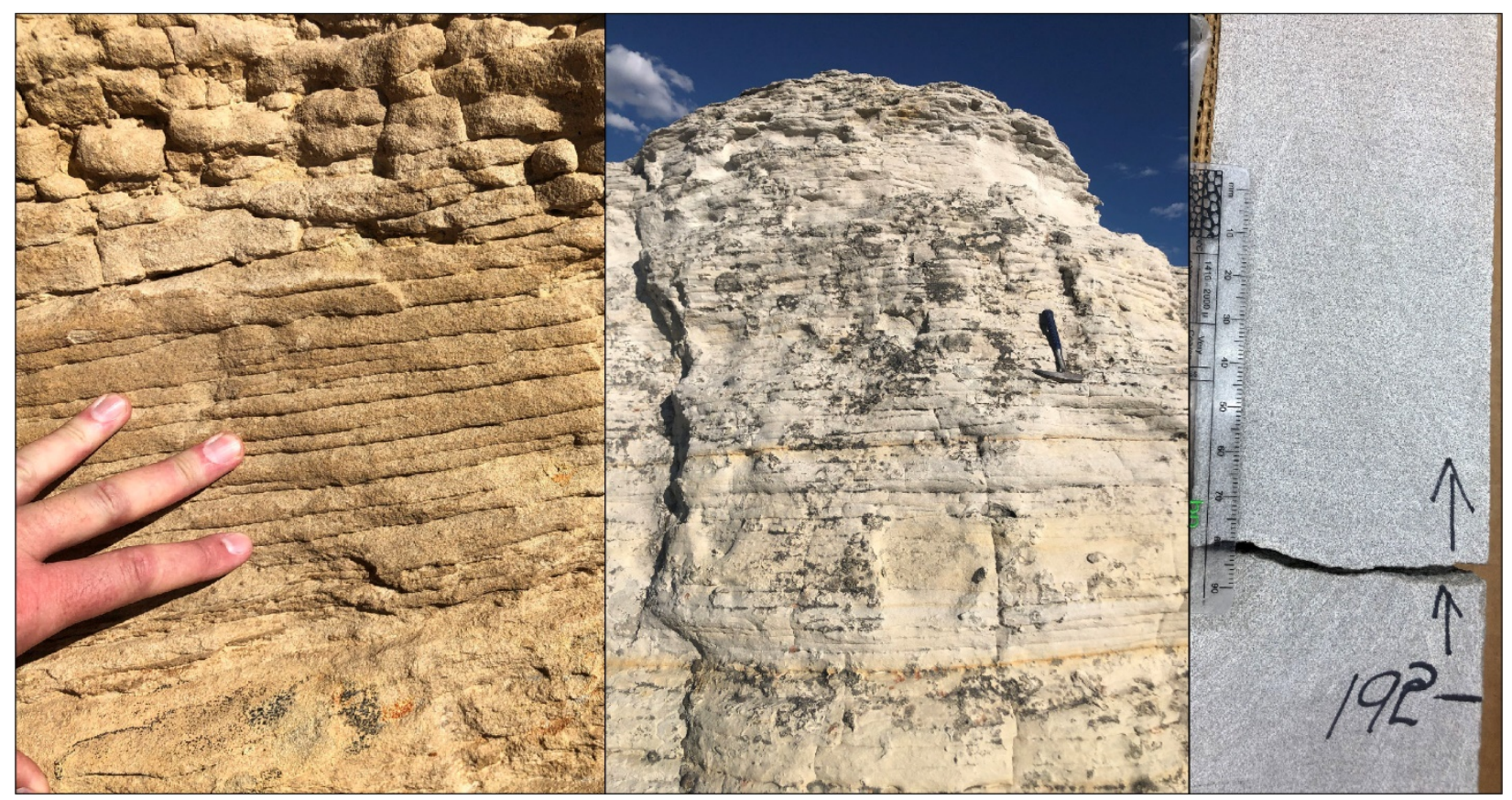

Figure 22. Left two photos showing sizeable planar laminated marine sandstone found on the west side of the basin at the Rock Springs Uplift. Right photo showing planar bedded facies in core (DM-D99 Doty Mountain)

Facies 15: Ripple-Laminated Interbedded Sandy/Siltstone

One of the first observations made at the close of each measured section to the east side of the basin was that although marine facies were described, a stratigraphic contact with the Lewis Shale was never evident. It is clear that a portion of upper Almond strata has been eroded and is not available to characterize. In order to quantify how much section is missing and what exactly those facies are, a description of a nearby core that includes an obvious contact with the overlying Lewis Shale was completed. Facies 4, 11, 12, and 14 were all located in the core with two additional facies not previously discussed. This facies is composed of a siltstone with very fine sandstone stringers and woody detritus. It is mainly found to be wave-ripple laminated with some small-scale burrows (Skolithos, Planolites, Chondrites) (Figure 23). The presence of this ichnofacies paired with syneresis cracks distinguish this facies from Facies 2 and 3. This facies was often found overlying upper shoreface-foreshore sands of Facies 14. It is interpreted to represent variable energy, partly protected bayfill sediments or an estuarine 
environment that included input from freshwater streams. Sand-filled syneresis cracks are indicative of variable salinity (MacEachern et al., 2011). It is always found to be overlain by a proximal coal. Its stratigraphic position relative to proximal coals and shoreface sands suggest that variously flooded areas were present along the paleoshoreline.

Facies 16: Laminated Gray/Black Shale

This facies is found common both in the core and in outcrop, overlying proximal coals or upper shoreface/foreshore sands. It is a dark gray to black colored shale representing a flooding surface brought on by relative sea-level rise (Figure 23).

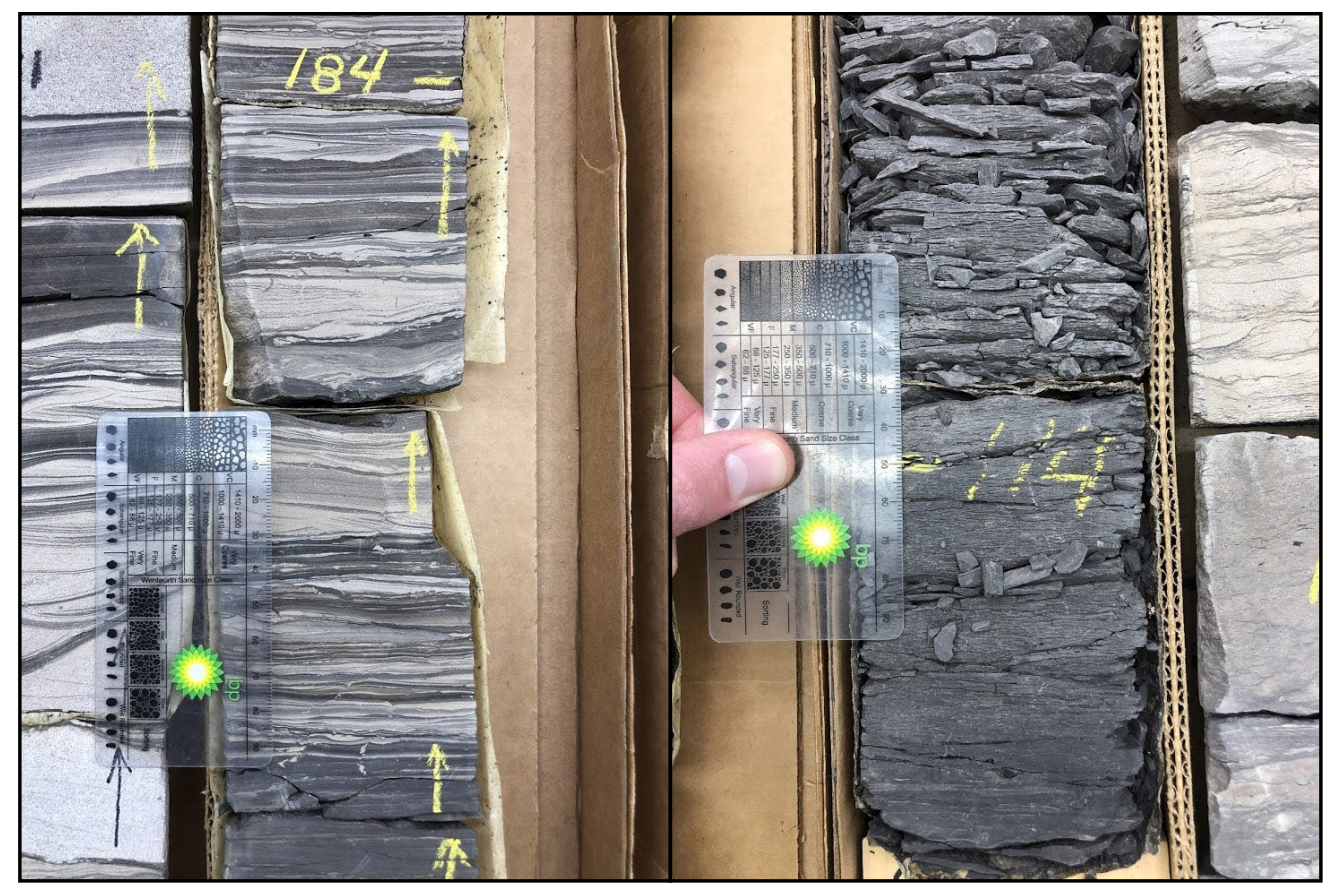

Figure 23. Image to the right shows ripple-laminated interbedded sandy siltstone with bioturbation and syneresis cracks. Image on the right shows marine shale. Both were found in core on the east side of the basin. 
Table 1-Almond Formation Facies

\begin{tabular}{|c|c|c|c|c|}
\hline $\begin{array}{l}\text { Facies } \\
\text { Code }\end{array}$ & Facies Name & Facies Description & Fossils \& Ichnology & Facies Association \\
\hline F1 & $\begin{array}{l}\text { Trough Cross- } \\
\text { Stratified } \\
\text { Sandstone }\end{array}$ & $\begin{array}{l}\text { Trough cross stratified VF-F } \\
\text { grained Sandstone, quartz } \\
\text { dominated, well sorted, } \\
\text { woody fragments, single } \\
\text { and multi-storey }\end{array}$ & & Coastal Plain \\
\hline $\mathrm{F} 2$ & $\begin{array}{l}\text { Carbonaceous } \\
\text { Shale }\end{array}$ & $\begin{array}{l}\text { Fissile shale containing } \\
\text { carbonaceous debris, dark } \\
\text { grey to black }\end{array}$ & & $\begin{array}{l}\text { Coastal Plain, } \\
\text { Estuarine/Lagoonal }\end{array}$ \\
\hline F3 & Fissile Silty-Shale & $\begin{array}{l}\text { Silt and clay sized grains } \\
\text { with occasional sand } \\
\text { stringer, sand stringers can } \\
\text { contain carbonaceous } \\
\text { debris, dark brown }\end{array}$ & & Coastal Plain \\
\hline F4 & Coal & Coal & & Coastal Plain \\
\hline F5 & $\begin{array}{l}\text { Heterolithic Cross- } \\
\text { Stratified } \\
\text { Sandstone }\end{array}$ & $\begin{array}{l}\text { Trough cross stratified } \\
\text { sandstone with occassional } \\
\text { planar laminations and } \\
\text { climbing ripples, heterolithic } \\
\text { laminations common, mud } \\
\text { rip-ups, and channel lag, } \\
\text { abundant soft sediment } \\
\text { deformation }\end{array}$ & & Coastal Plain \\
\hline F6 & $\begin{array}{l}\text { Ripple-laminated } \\
\text { Silty-Sandstone }\end{array}$ & $\begin{array}{l}\text { Oscillatory ripple laminated } \\
\text { sand and silt, planar } \\
\text { lamination, indistinct } \\
\text { bioturbation, oxidized and } \\
\text { poorly exposed }\end{array}$ & & Coastal Plain \\
\hline F7 & $\begin{array}{l}\text { Planar-Laminated } \\
\text { Sandstone }\end{array}$ & $\begin{array}{l}\text { Planar laminated VF-F } \\
\text { sandstone, small scale } \\
\text { vertical burrows }\end{array}$ & & Coastal Plain \\
\hline F8 & $\begin{array}{l}\text { Mud-Draped Small- } \\
\text { Scale Trough Cross } \\
\text { Stratified } \\
\text { Sandstone }\end{array}$ & $\begin{array}{l}\text { Trough cross stratified VF } \\
\text { grained sandstone with } \\
\text { notable mud drapes, low } \\
\text { diversity of small scall } \\
\text { burrows }\end{array}$ & & Estuarine/Lagoonal \\
\hline F9 & $\begin{array}{l}\text { Trough Cross and } \\
\text { Ripple Laminated } \\
\text { Sandstone w/ } \\
\text { Bivalves }\end{array}$ & $\begin{array}{l}\text { Trough cross stratified VF } \\
\text { grained sandstone, large } \\
\text { scale troughs with wave } \\
\text { ripples, mud rip-ups }\end{array}$ & Bivalves & Estuarine/Lagoonal \\
\hline F10 & Oyster Beds & $\begin{array}{l}\text { Sandstone containing } \\
\text { abundant oysters either as } \\
\text { channel lag or laterally } \\
\text { dispersed }\end{array}$ & Oysters & $\begin{array}{l}\text { Estuarine/Lagoonal, } \\
\text { Marine }\end{array}$ \\
\hline F11 & $\begin{array}{l}\text { Hummocky Cross- } \\
\text { Stratified } \\
\text { Sandstone }\end{array}$ & $\begin{array}{l}\text { VF grained sandstone with } \\
\text { both hummocks and swales }\end{array}$ & $\begin{array}{l}\text { Thalassinoides, } \\
\text { Planolites, } \\
\text { Asterosoma }\end{array}$ & Marine \\
\hline
\end{tabular}




\begin{tabular}{|c|c|c|c|c|}
\hline $\begin{array}{l}\text { Facies } \\
\text { Code }\end{array}$ & Facies Name & Facies Description & Fossils \& Ichnology & Facies Association \\
\hline F12 & $\begin{array}{l}\text { Bioturbated Trough } \\
\text { Cross-Stratified } \\
\text { Sandstone }\end{array}$ & $\begin{array}{l}\text { Trough cross stratified VF-F } \\
\text { grained sandstone with } \\
\text { marine burrows }\end{array}$ & $\begin{array}{l}\text { Skolithos, } \\
\text { Ophiomorpha, } \\
\text { Paleophycus }\end{array}$ & Marine \\
\hline F13 & $\begin{array}{l}\text { Heavily Bioturbated } \\
\text { Ripple-Laminated } \\
\text { Sandstone }\end{array}$ & $\begin{array}{l}\text { Vf grained wave ripple } \\
\text { laminated sandstone with } \\
\text { some planar laminations }\end{array}$ & $\begin{array}{l}\text { Arenicolites, } \\
\text { Skolithos, } \\
\text { Conichnus, } \\
\text { Ophiomorpha, root } \\
\text { traces }\end{array}$ & Marine \\
\hline F14 & $\begin{array}{l}\text { Planar-Laminated } \\
\text { Marine Sandstone }\end{array}$ & Planar bedded FG sandstone & Ophiomorpha & Marine \\
\hline F15 & $\begin{array}{l}\text { Ripple-Laminated } \\
\text { Interbedded Sandy- } \\
\text { Siltstone }\end{array}$ & $\begin{array}{l}\text { Predominantly ripple } \\
\text { laninated siltstone with } \\
\text { interbedded sand stringers, } \\
\text { woody debris, syneresis } \\
\text { cracks, }\end{array}$ & $\begin{array}{l}\text { Skolithos, } \\
\text { Planolites, } \\
\text { Chondrites }\end{array}$ & Estuarine/Lagoonal \\
\hline F16 & Laminated Shale & Dark grey to black shale & $\begin{array}{l}\text { Schaubcylindrichnus } \\
\text { Freyi }\end{array}$ & Marine \\
\hline
\end{tabular}

\section{Facies Associations}

Facies previously described can be grouped into three coherent facies associations based on sedimentary structures, grain type, diversity of bioturbation, and stratigraphic stacking patterns. The three main facies associations found in outcrop and core are coastal plain/delta plain, estuarine/lagoonal, and marine (Figure 24). 


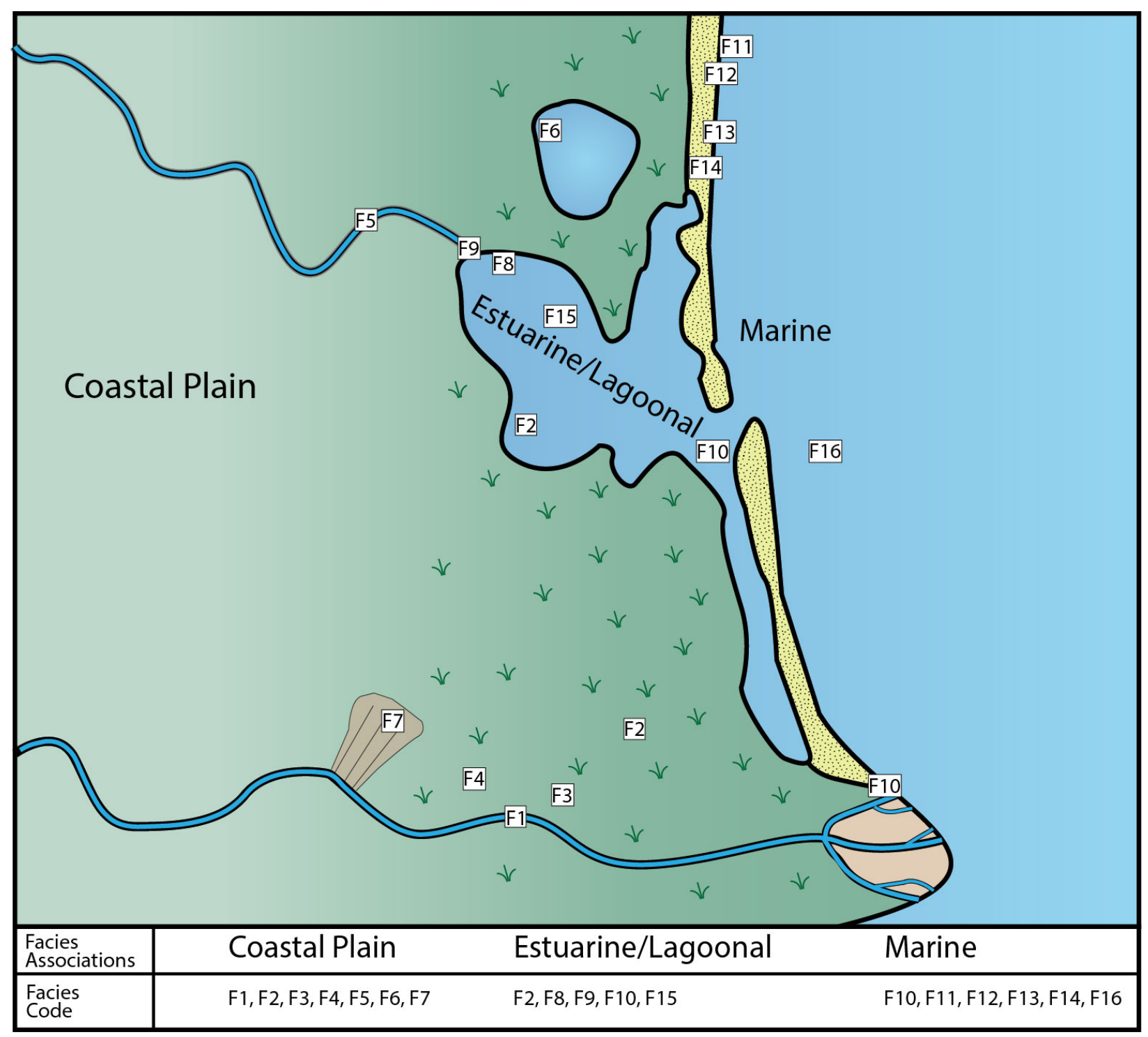

Figure 24. Generalized illustration showing interpreted facies associations of coastal plain, estuarine, and marine depositional environments of the lower and upper Almond. Each facies is labeled as with an (F) coinciding with notation in previous descriptions.

Facies 1-7 are found in close association in outcrop and together suggest an overall continental deposition (Figures 25, 26). Trough cross-stratified sandstones (Facies 1) that are lensoidal in shape are commonly flanked by carbonaceous shales, coal, and brown fissile siltstones containing woody debris (Facies 2, 3, 4). Occasionally, these three facies are also closely associated with planar-laminated, sheetlike sandstones (Facies 7). As facies begin to shift closer to a nearshore environment, channelized features 
become more abundant including heterolithic trough cross-stratified sandstones with abundant softsediment deformation and oxidized symmetrically rippled sandstones (Facies 5,6). The coastal plain depositional environment along with the above described facies association is interpreted to represent a low-lying, flat stretch of land with ample vegetation. This area was incised by meandering streams, distributaries, and flood plain deposits that became increasingly inundated with water as base level periodically and ultimately rose through time. Freshwater sourced from the Sevier Uplift carried sediment into this low-gradient environment where sediment was partially sequestered in channels, splays, and floodplains before distributary channels emptied into the CIS (Facies 1, 7) (Kieft et al., 2011). These streams, periodically entrained carbonaceous debris found mixed in muds and heterolithic sands found in outcrop (Facies 5). Much of the preserved vegetation is found as interspersed coals and carbonaceous shales (Facies 2, 3, \&4). Small bodies of standing water touched mostly by wind but sheltered from proximal marine waters are distributed throughout (Facies 6).

Facies 2, 8-10 and 15 are found in close association with each other in outcrop. Carbonaceous shales are found underlying and flanking trough cross-stratified sandstones that are mud draped, ripple laminated, and contain bivalves (Facies 2, 8,9). Facies 8 and 9 are not necessarily found adjacent to Facies 10 and 15, but all four contain evidence for variable salinity. The estuarine/lagoonal depositional environment is interpreted as the zone in which freshwater mixes with marine waters before moving completely into the marine dominated zone. The morphology of the paleo-shoreline of the CIS appears to have been quite complex with a mixture of classic shoreline indicators as well as obvious lagoonal/embayment features. This association includes distributary channels entering an often flooded environment where bivalves are found alongside trough cross-stratified and oscillatory rippled sandstones (Facies 9). Some of these channelized features contain large-scale mud drapes indicating a mixture of grain size and flow regime (Facies 8). Sediment input varies in this zone, including not only channel sands, but undisturbed fine-grained detritus protected from waves by lagoons (Facies 10, 15). These 
lagoonal features are characterized by thinly interbedded siltstones and sandtsones containing abundant oysters, synerisis cracks, and ichnofacies that indicate a nearshore environment (Facies 10, 15).

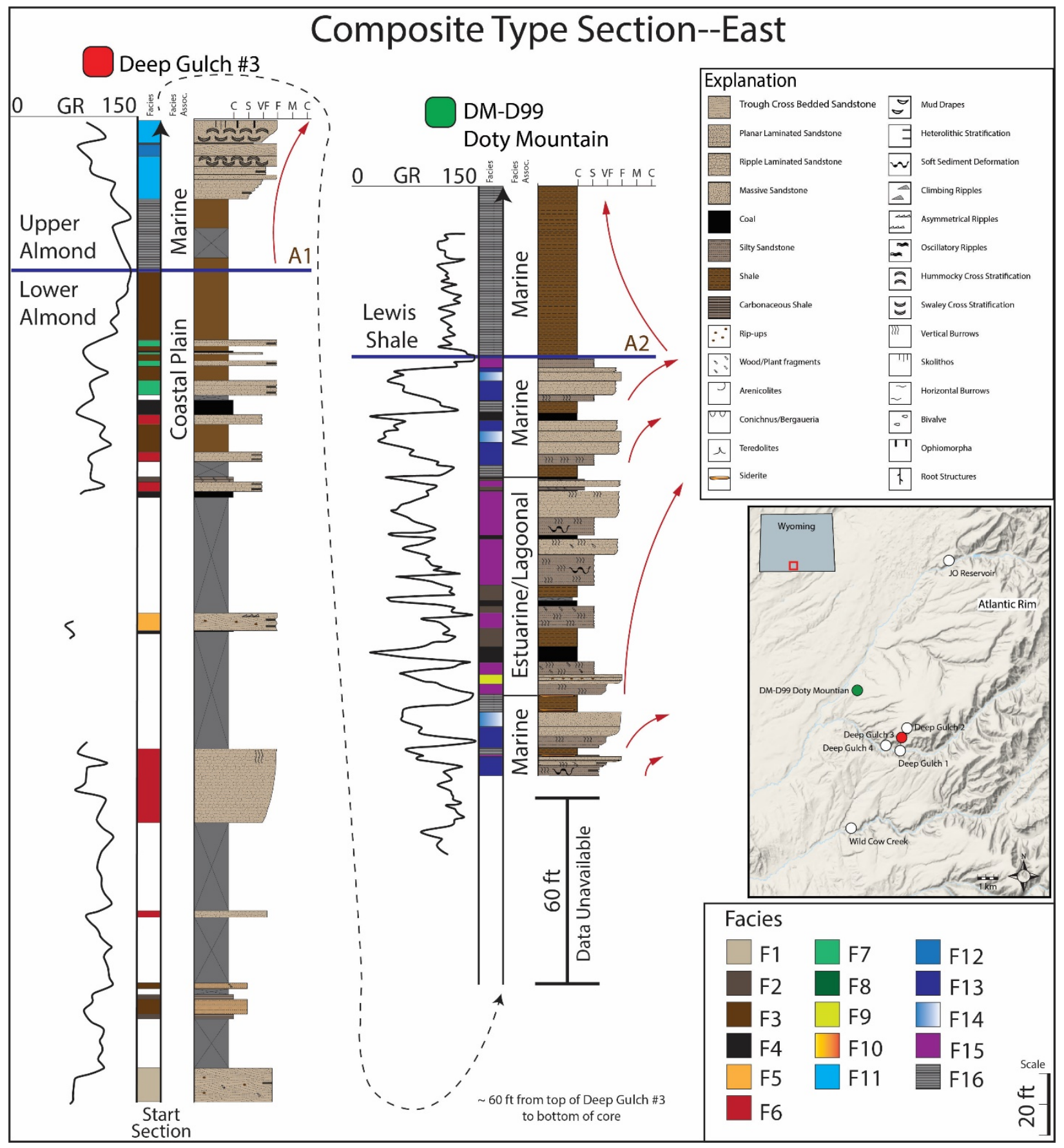

Figure 25. Figure illustrating facies stacking relationships and their associations for Atlantic Rim strata of the Almond Formation. Figure integrates data acquired from outcrop and core as a composite type section in order to properly demonstrate the most complete picture of facies shifts from coastal plain to fully marine strata. 
Facies 10-14 and 16 are closely associated with each other in outcrop and related depositional facies. Hummocky, trough, and planar cross-stratified sandstones with marine traces and occasional thick oyster deposits are found to be associated very closely due to marine stacking patterns within shoreface or delta-front strata (Facies 10-12 \& 14). These facies are also associated closely with the marine shale facies (Facies 16) as relative sea-level rise caused it to directly overly Facies 12 and 14. The heavily bioturbated and ripple-laminated sandstone facies (Facies 13) is not directly associated with the others described in outcrop, but exhibits many marine fossils that placed it in close association. The marine facies association is interpreted as clastic shoreline that opens to brackish lagoons and barrier bars with perhaps some

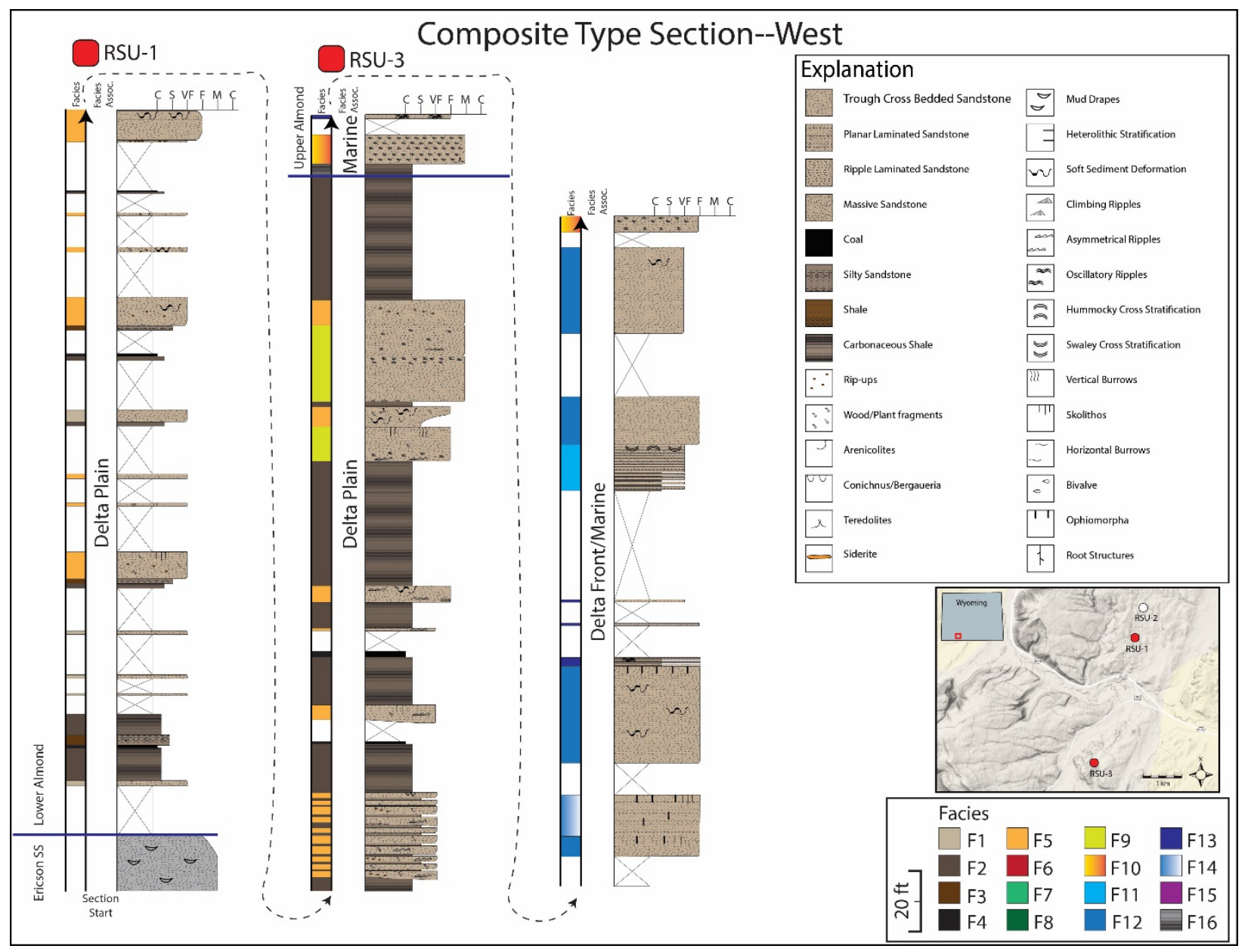

Figure 26. Figure illustrating stacking relationships of facies and their associations of the Rock Springs Uplift strata. Figure integrates data acquired at two field localities (RSU-1 \& 3) as a composite type section in order to display 
facies and their associations from the Ericson Sandstone all the way to the Lewis Shale and as close to the Cherokee Arch as possible.

channelized deltaic influence (Facies 10). Sands sourced from the Sevier Uplift are reworked and dispersed along the shoreline by longshore drift producing beaches and spits with planar beds (Facies 14). Waves constantly interrupted and redirected sands of the upper shoreface while only storms disrupted the more distal sediments below fair-weather wave base (Facies 11, 12).

\section{Discussion}

Spatial and Temporal Trends

In order to correlate outcrop and core observations across the central Cherokee Arch, as well as to add further detail to areas of outcrop study, $\log$ from 71 wells were analyzed. Three main tops (A1, A2, and A3) were evident and instrumental in the reconstruction of the subsurface along the Cherokee Arch (Figure 27). Each of these can be easily detected using gamma-ray curves that illustrate a measurement of the quantity of naturally occurring gamma radiation present in the rock and can be used to characterize lithology. These surfaces that indicate a high gamma-ray value represent flooding surfaces and are spaced throughout Almond stratigraphy such that they can be used to piece together the depositional history. Marine sandstone packages can be split into two packages that coincide with the division between the lower and upper Almond along the Rock Springs Uplift across the field area, which are divided by the A2 surface (Figure 27). A progradational stacking pattern near the eastern outcrops and another retrogradational stacking pattern of clean sands in the upper Almond near the Rock Springs Uplift. The upper Almond sands are larger, better preserved, and they span a large basinward distance. 


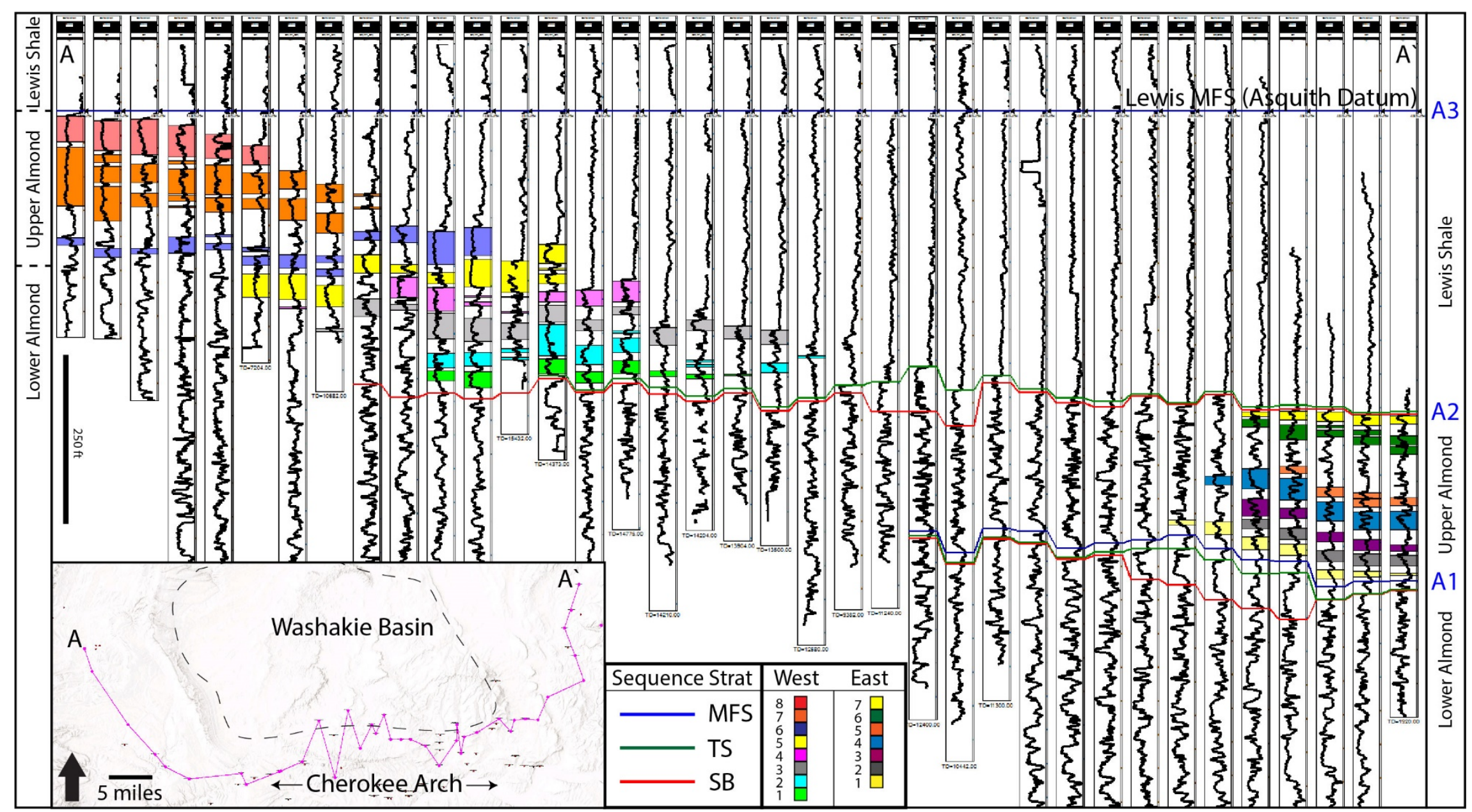

Figure 27. Regional chronostratigraphic cross-section detailing sequence stratigraphic relationships as well as marine strata on both east and west sides of the basin. 
Measured sections from the Atlantic Rim to the east were tied to nearby well logs in an effort to define thickness of non-preserved upper Almond facies (Figure 28). Lower Almond fluvial sands and associated overbank deposits cannot be reliably correlated due to a lack of channel lateral continuity. Consequently, laterally continuous marine sands with overlying coals were interpreted on adjacent well $\log$ data and used to correlate chronostratigraphic cycles (surface A1). An upper Almond, marine facies can be distinguished from the lower Almond fluvial facies by following this pattern and subsequent measured sections are hung on this interpreted interface. In addition, the scintillometer curve taken in the field correlates perfectly with this interface as a regionally extensive flooding surface that can be seen as a distinctively high gamma-ray value (surface A1). With this interpretation made, roughly $200 \mathrm{ft}$. of upper Almond stratigraphy is found to be missing in outcrop while that thickness is represented by several marine cycles with up to $15 \mathrm{~km}$ of laterally continuous coals in well log data. Each cycle found in wells adjacent to measured sections show gamma ray signals for progradational packages often topped by coals. Coals are interpreted by a relatively low gamma ray count and a significantly low bulk density value. The presence of correlative marine strata along the Atlantic Ridge is significant as it adds new evidence for a progradational sequence set not fully characterized before. This suggests a more significant shoreface presence on the east side of the basin. 


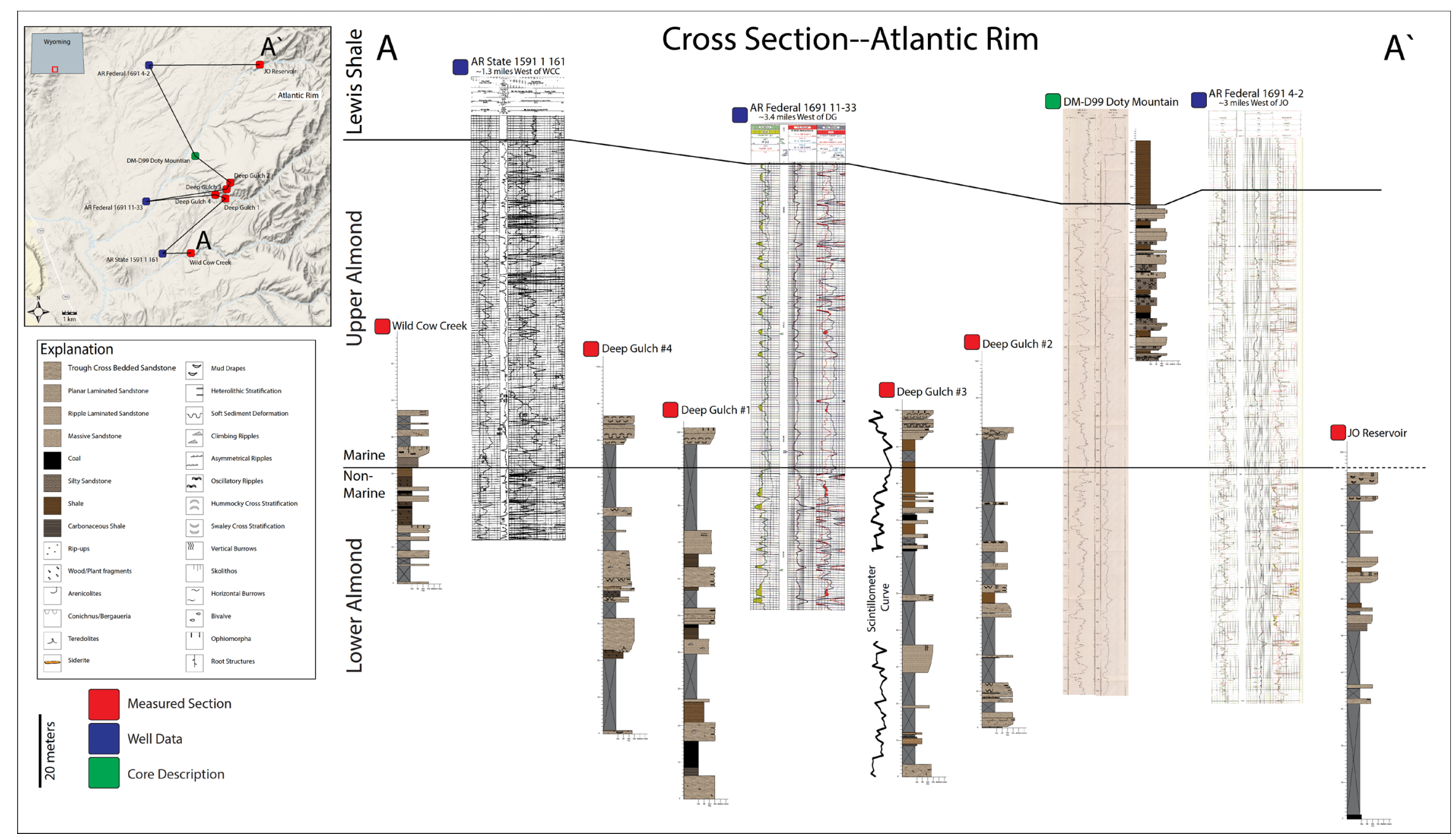

Figure 28. Correlation panel showing where the measured sections on the east side of the basin correlate with the core description and nearby well data using surface A1. 
According to facies associations identified in logs (based on correlation with core and outcrop), approximate shoreline location along the Cherokee Arch was identified for 15 separate parasequences of lower and upper Almond. There is insufficient data to know the exact directional trend of the paleoshoreline away from control, but based on well data and previous studies, a general N-S shoreline trend is estimated with a more NW-SE trend in the east (Figure 29) (Roehler, 1988). It is reasonable to assume a shoreline trend that is oblique to well data at a generally NW to SE trend but more well control is needed to place it exactly.

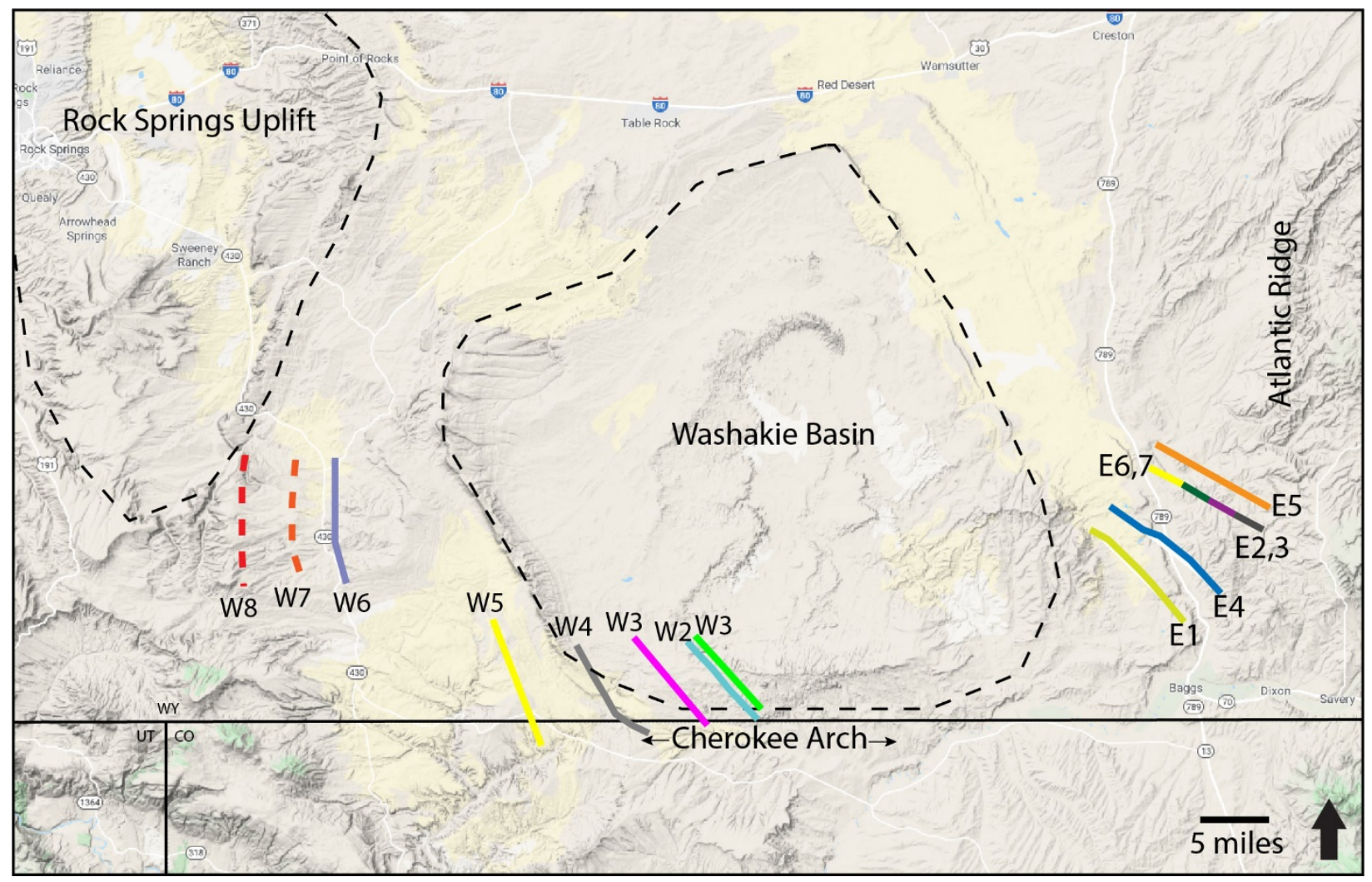

Figure 29. Illustration showing the western extent of each marine shoreline on both sides of the basin. This illustration shows the magnitude of the transgression, where shorelines pervaded at different times of Almond deposition, and the distance of non-marine hiatus in deposition. Each shoreline is numbered and colored to match their interpreted parasequences and temporal relationships. 


\section{Sequence Stratigraphy}

Providing a sequence-stratigraphic framework for the deposition of nearshore to marine sands along the Cherokee Arch provides a predictive framework in which to evaluate the size, spatial extent, and connectivity of Almond reservoirs. Almond strata can be divided into three main packages by using a few laterally extensive chronostratigraphic and distinctive tops (Figure 30). The initial highstand systems tract is bound by a sequence boundary (SB1) (Van Wagoner \& Mitchum, 2003). Sequence 1 begins at this sequence boundary and is interpreted to be synonymous with the transgressive surface TS1. There is at least circumstantial evidence for incised-valley fill associated with this transgressive systems tract (TST1). This is the preferred interpretation although it is entirely possible that these clean and thicker sands are part of a distributary system and that SB1 could be placed directly above them. Either way, there is a thinly preserved deposit that is roughly 20 feet thick that spans the distance between TS1 and the first maximum flooding surface (MFS1). This surface extends at least 25 miles to the west and separates lower Almond stratigraphy from upper Almond on the east side of the basin. After MFS1, a thick succession of coastal plain and marine strata progrades and ultimately aggrades representing the first highstand systems tract (HST1). This is where the marine strata found to the east in core and outcrop reside. SB2 tops HST1 with another postulated incised valley fill and subsequent TS2.

Examination and interpretation of log curve data in Sequence 2 suggests that there are at least eight parasequences of prograding marine sandstone within a retrogradational, transgressive systems tract (TST2). The Lewis MFS (Asquith Datum), which represents maximum flood, is a conspicuously high gamma-ray value on log curves that marks the maximum extent of the transgressive systems tract and Almond strata. Each marine parasequence stacks progressively landward from the previous in a significantly thicker and surprisingly well preserved TST2. 


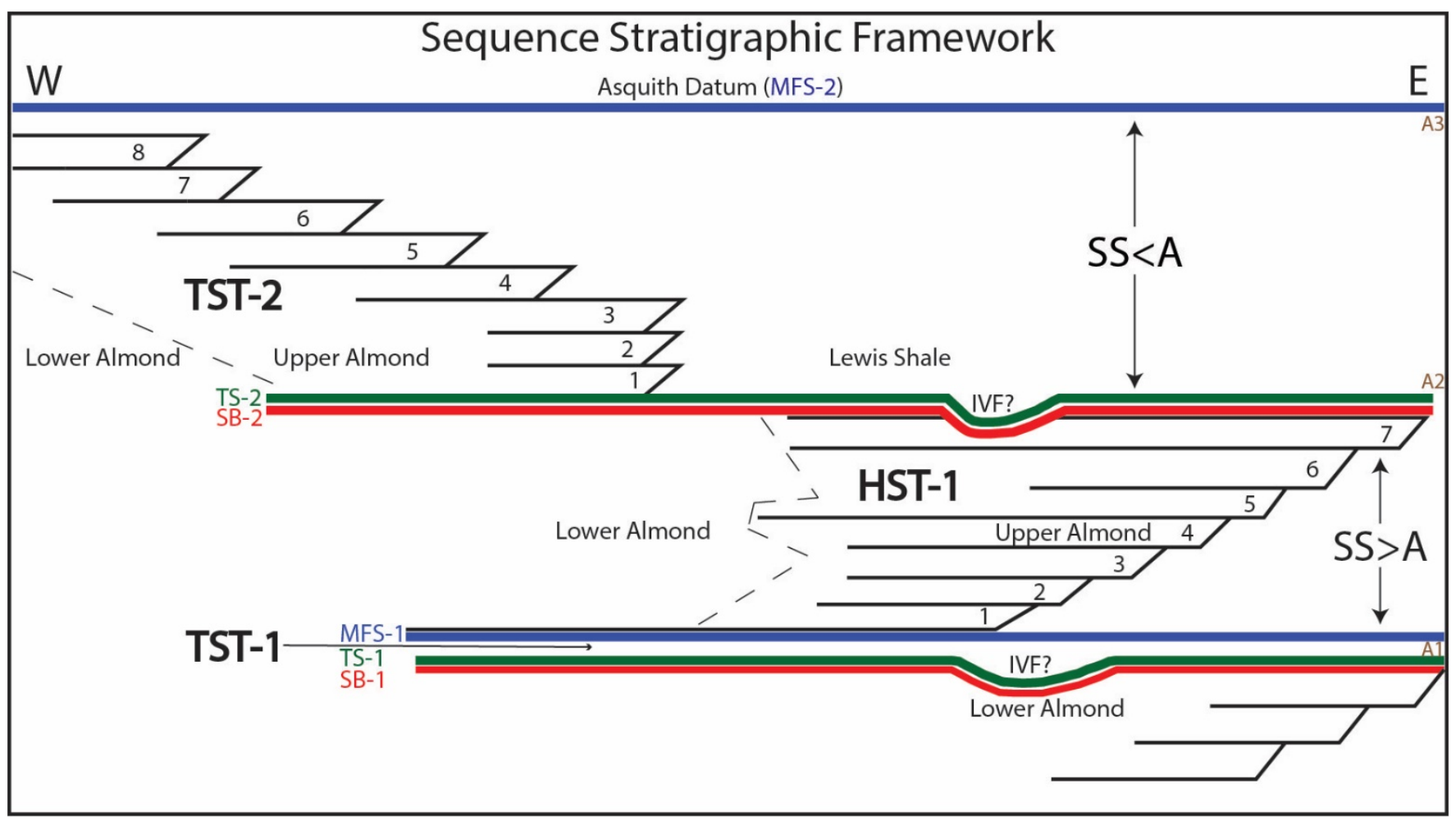

Figure 30. Illustration demonstrating the interpreted sequence stratigraphic framework for the entire length of the Cherokee Arch. This figure also shows how lower and upper Almond stratigraphy fit into the interpretation. Transgressive systems tract (TST), highstand systems tract (HST), incised valley fill (IVF), maximum flooding surface (MFS), transgressive surface (TS), sequence boundary (SB), sediment supply (SS), and accommodation (A) have all been abbreviated.

Often, preserved transgressive deposits are thin and in many cases are not preserved at all (Van Wagoner \& Mitchum, 2003). This is usually a result of cannibalization of shallow marine deposits as relative sea-level rises. However, according to our interpretation, interval A3 represents a thick preserved transgressive systems tract composed of eight identified parasequences. A possible explanation for this uncharacteristic preservation is that subsidence brought on by local, early Laramide tectonic activity created space sufficient for preservation of shallow-marine strata during shoreline retrogradation.

Facies stacking relationships in outcrop along the Rock Springs Uplift supports well log sequence stratigraphic interpretations, showing an initial progradation in the lower Almond coastal plain.

Channelized sands that immediately overlie the Canyon Creek Member of the Ericson Sandstone are thin, laterally discontinuous, and uncommon (Figure 26). Similar channelized sands up-section become thicker, 
more laterally continuous, and ubiquitous. In short, parasequences containing channel sands display an increase in net/gross up-section suggesting an early progradation of facies. Since fluvial accommodation in a system can respond to changes in marine accommodation within the same system, this fluvial progradation correlates well with the marine progradation of HST1 and places confidence in the subsurface correlation (Miall et al., 2011) (Figure 30).

The western outcrops and log curves are characterized by thick, blocky marine sandstones directly overlying multistory deltaic channel complexes. At first glance, the measured section at Dry Canyon reveals a clean transition into marine shoreface sandstones with typical sedimentary structures that would indicate lower shoreface to foreshore (Figure 26). However, there is evidence that indicates a high amount of sediment delivery. The RSU-3 section demonstrates that as coastal plain fluvial facies transition into brackish conditions, there is a mixture of soft sediment deformation, current ripples, rip-up clasts, carbonaceous debris, Teredolites traces, and large amounts of oysters (Figure 31). This zone is interpreted as near shore deltaic. In addition, as the section becomes more marine dominant, soft sediment deformation continues to be abundant along with carbonaceous material, oysters, and Ophiomorpha. There are also some lensoidal sand bodies that scour marine sands demonstrating a delta front environment. One in particular is found to be filled with oysters in a narrow one meter swath through upper shoreface. Clinoforms are prevalent in the top two parasequences and are found to range from 1030 meters in thickness, which is indicative of delta style clinoforms (Patruno \& Helland-Hansen, 2018) (Figure 32). Wave dominated deltas are difficult to distinguish from classic shoreface systems (Bhattacharya \& Sheriff, 2006). However, if the sedimentary evidence described is combined with interpreted clinoforms in the uppermost parasequence to the west and the extra sand package that only exists in the southern wells, a deltaic influence is reasonable. 


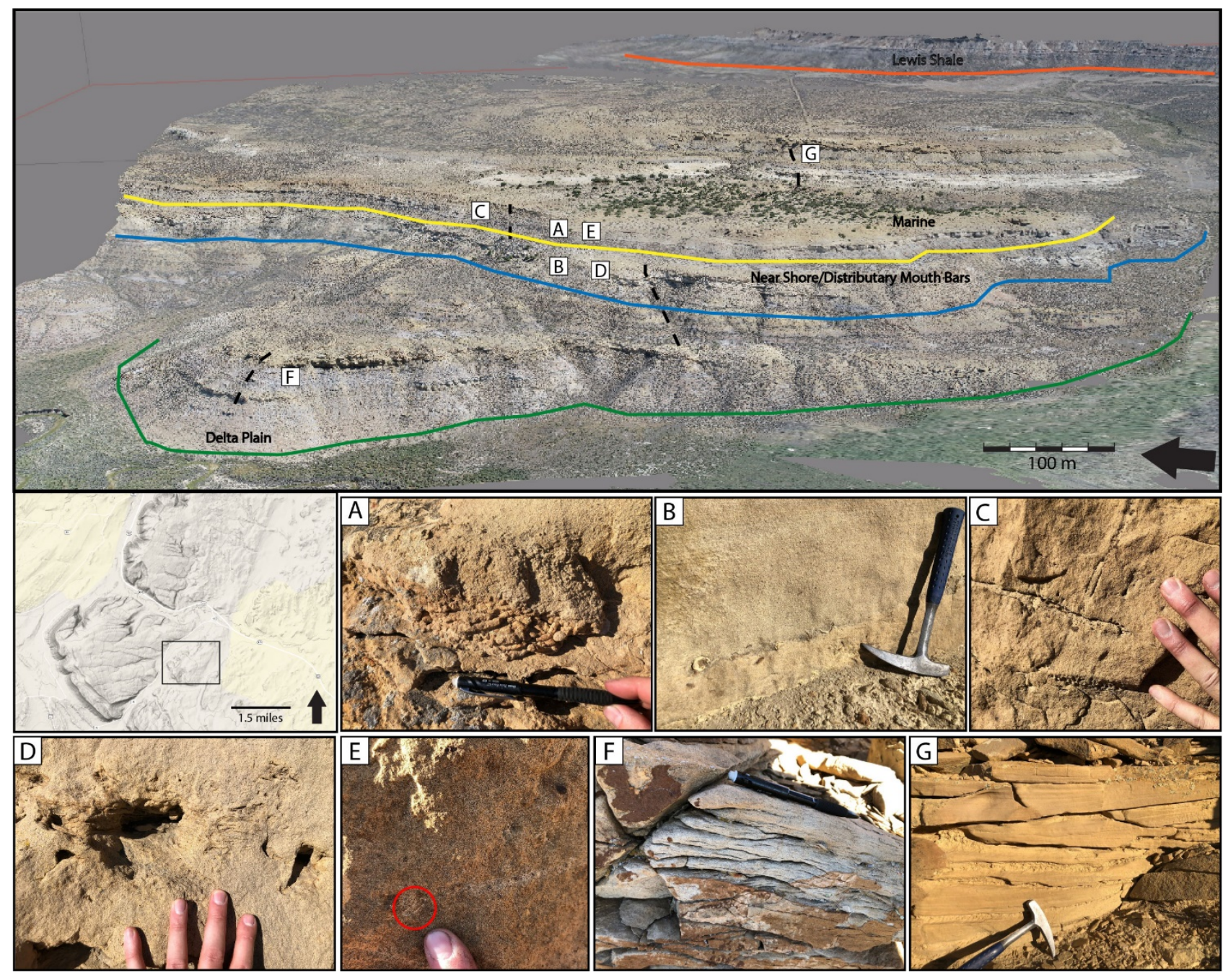

Figure 31. Virtual outcrop of Dry Canyon where RSU\#3 was taken, displayed as a tiled photogrammetric model. Annotations illustrate major interpreted facies changes. The dotted black line shows the locations of measured section and offsets. Each of the facies photos allows for close-up examination of deltaic evidence. (A) Woody fragment with Teredolites burrows. (B) Oysters as a channel lag in nearshore environment. (C) Ophiomorpha burrows. (D) Another chunk of wood with Teredolites burrows. (E) Paleophycus burrow in marine sandstone. (F) Ripple laminations in trough cross stratified sandstone. (G) Hummocky cross-stratified sandstone. 

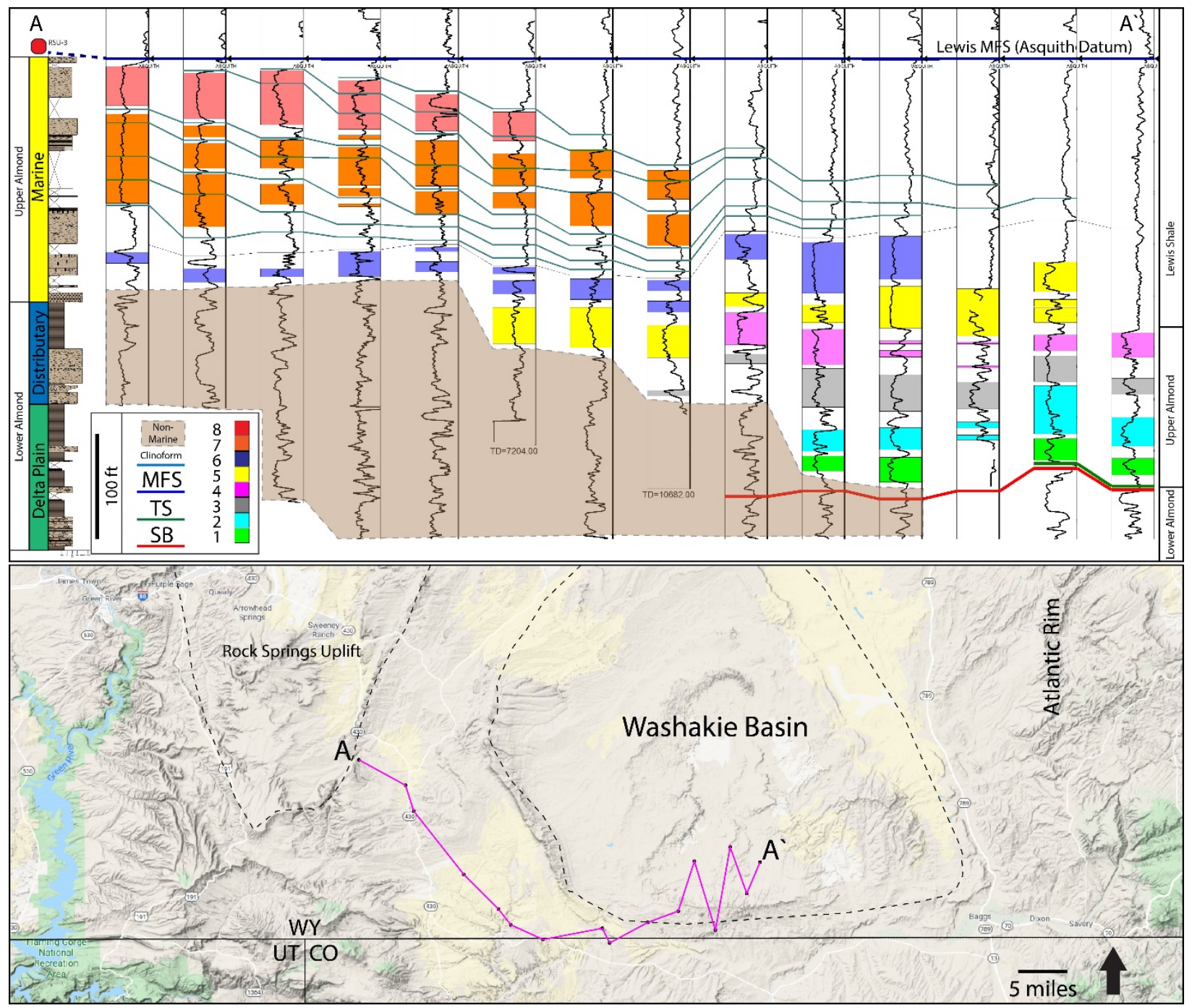

Figure 32. Measured section (RSU\#3) of the Almond Formation in Dry Canyon on the west side of the basin coupled with nearby subsurface data. The cross section line in the map includes the measured section. Illustration shows the relationship between facies described in outcrop to subsurface interpretations.

There is evidence for a transition from a coastal plain, freshwater dominated system to a more lagoonal environment as stacking patterns approach marine conditions (Figure 25). This evidence is found in outcrop and the core description and consists of facies that indicate a change in salinity (Figure 33). Evidence to support a lagoonal system is threefold. First, measured sections record coastal plain fluvial sandstones surrounded by carbonaceous shales that eventually transition into fluvial sandstones including bivalves and wave ripples (Facies 9). This outcrop evidence demonstrates a potential change in salinity 
coupled with sedimentary structures that are commonly found in a nearshore environment. Secondly, syneresis cracks are found in the core in an abundant way throughout the middle of the core suggesting that salinity changes occur (Burst, 1965; MacEachern et al., 2011). This section of core is also finer grained, wave rippled, and has a high non-marine bioturbation index. Thirdly, the stacking patterns suggest marine sands give way to bayfill facies before floodback or proximal coals. However, bayfill facies may be present in stacking patterns of the core but not always, suggesting some complexity and heterogeneity in the morphology of the paleoshoreline. This interpreted depositional model for the east leans heavily on the presence of bayfill facies found in core and in outcrop and suggests a high level of complexity as the bayfill sediments are not always preserved. The simplest explanation for this is a periodic lack of preservation or complete loss of bayfill record as a result of wave ravinement during transgressive migration of potential barrier bar sands (Swift, 1968). Alternatively, the autogenic responses of distributary avulsion and shoreline morphology perhaps allowed for proximal coals to stack directly above foreshore sand.

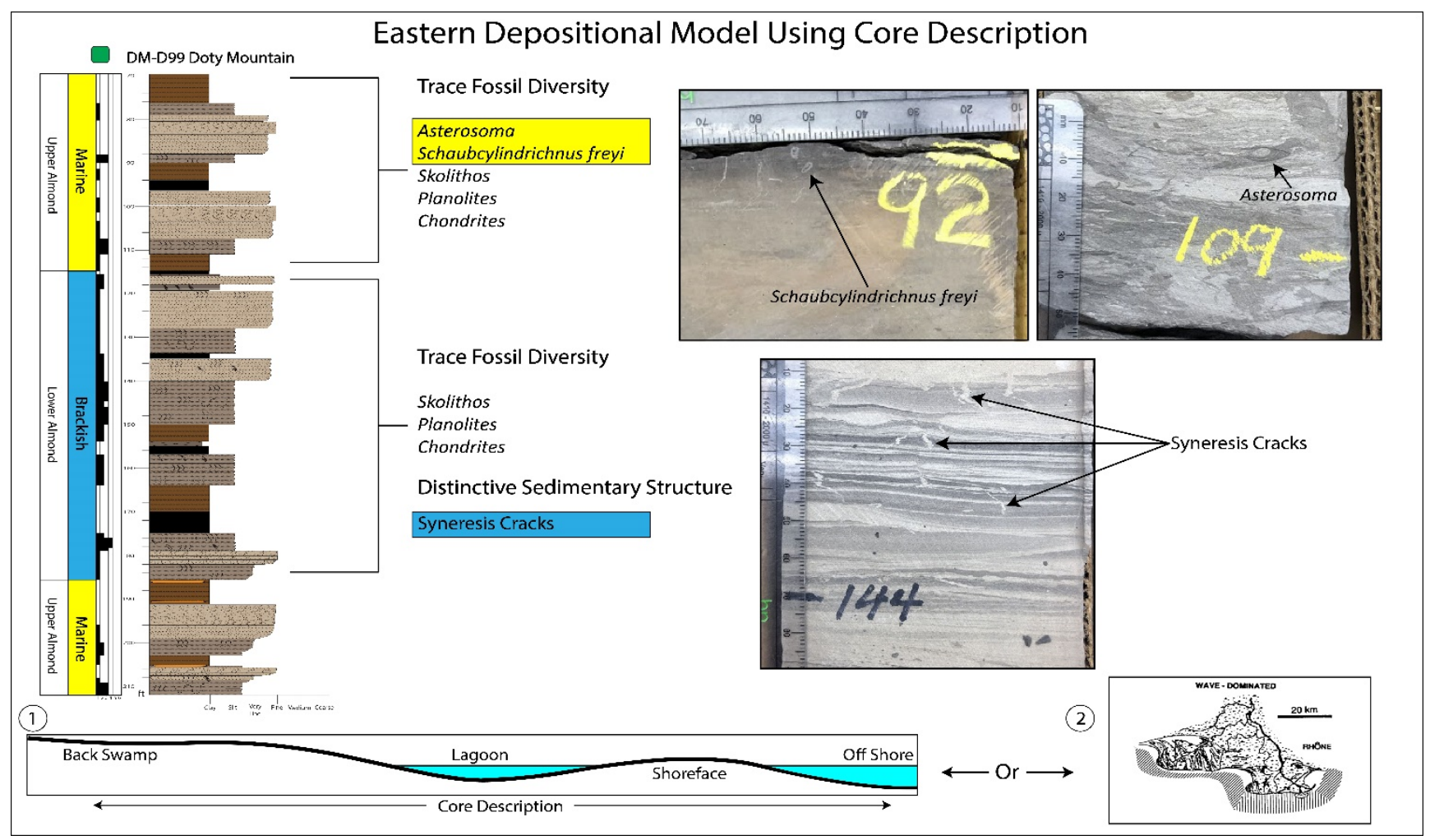

Figure 33. Illustration including the eastern core description and its implications for interpreted depositional environments. 
Another possible interpretation for the depositional environment to the east is that there is a deltaic influence in addition or in lieu of a lagoonal system. The syneresis cracks and trace assemblage fits this idea as well since salinity often changes with fresh water being added to the system (MacEachern et al., 2011). This could also describe some of the small scale slumping, soft sediment deformation, and carbonaceous debris found in the core. Moreover, an interpreted distributary channel scour was found to truncate shoreface sands in outcrop at Deep Gulch. A separate channel complex in Deep Gulch but in the lower Almond was found to contain a bivalve fossil in what is being interpreted as a brackish, near-shore environment.

The trace fossil diversity suggests that the two upper parasequences are marine. The assemblage for interpreted marine facies identified in core are Asterosoma, Schaubcylindrichnus freyi, Skolithos, Planolites, and Chondrites. While most of these traces can be found in marine environments, the Asterosoma trace is a marine burrow found in middle to upper shoreface environments specifically (Knaust, 2017). Asterosoma can also be found in the deltaic equivalent (MacEachern et al., 2011). This along with the classic coarsening upward parasequence stacking patterns observed in log curves suggests that marine sands are present (Figure 34). The core description and its associated log curve show marine influence early on, transitioning into a more brackish environment before being overtaken by the aforementioned upper two marine parasequences. This suggests that the middle, more brackish section of the core represents temporary progradation into more proximal facies. This facies either representing a delta plain or lagoonal system. 


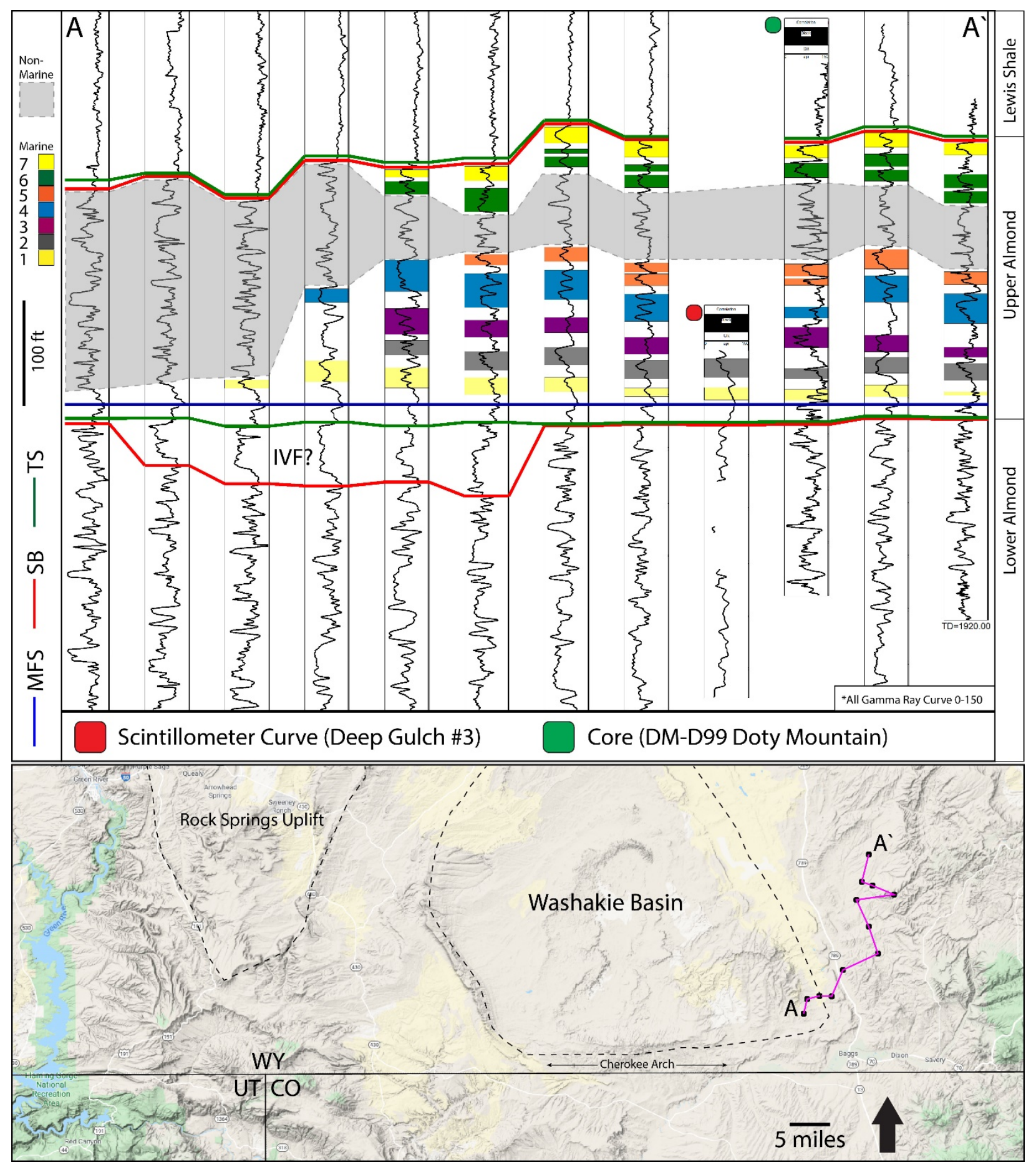

Figure 34. A closer look at the subsurface correlation panel to the east. This figure underscores the importance of the scintillometer data collected at Deep Gulch as well as the core description. Both of these data points are included as gamma ray curves here and were instrumental in interpreting an environment of deposition. 
Analysis of well logs shows important spatial trends not previously described for the Almond system. One such trend is clearly seen along the southern central flank of the Cherokee Arch. Well logs show an extra package of marine sands in southern wells and this sand extends a significant distance to the east (Figure 35). There are two possible explanations for this depositional pattern. The first and preferred interpretation is that the extra sand in southern wells represents an individual lobe of deltaic deposition. It is interpreted that there is a deltaic influence on parasequences in the west but most especially in wells in the south. As autogenic controls cause avulsion in a deltaic system, lobate deposition can independently distribute sediment and then migrate to a different location where more accommodation is available. Outcrop to the west including soft sediment deformation, abundant carbonaceous debris, and the presence of brackish Teredolites traces could suggest a deltaic influence (Bhattacharya \& Sheriff, 2006). Moreover, clinoformal geometries present in westernmost parasequences would support this interpretation. Previous research also shows a paleo-delta may have existed on the western shoreline to the south near the border of Colorado and Wyoming (Kieft et al., 2011; Roehler, 1990). The other explanation would involve a facies shift and shoreline morphology change extending the shoreline on a west to east trajectory for a considerable distance. This explanation is unlikely and is in opposition to previous research where shorelines have been mapped in a generally north to south trend. 

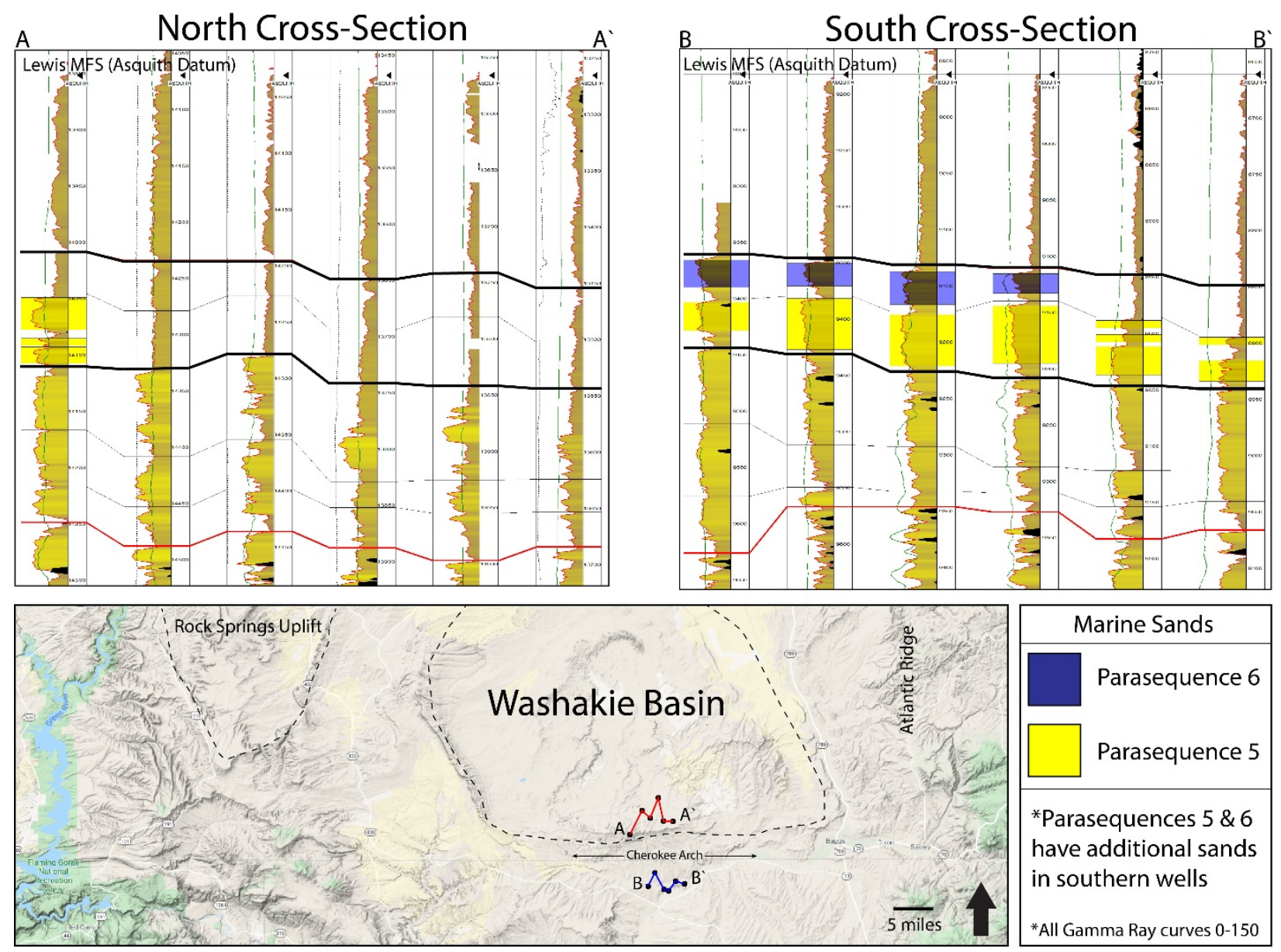

Figure 35. This figure shows two cross-sections of the Almond Formation roughly oriented perpendicular to depositional strike. The south cross-section clearly shows sand deposited at the same interval as shale deposition is occurring to the north.

The aim of this research was to integrate outcrop, core, and subsurface data in an effort to be more predictive about facies shifts and their effect on reservoir character in both space and time along the Cherokee Arch. As a result, marginal marine sandstones were identified and characterized throughout this structural feature and included in depositional models that would offer explanations for their origin and implications on the local Almond petroleum system. These potential hydrocarbon reservoirs were also analyzed using sequence stratigraphic principles that help define their connectivity. Understanding first the relationship of Almond marine strata to underlying coastal plain sediments and the overlying Lewis Shale was of paramount importance. Data shown throughout this paper demonstrates the depositional 
story of the entire Washakie Basin beginning with the eastern side of the basin. Almond strata at Atlantic Ridge shows initial coastal plain deposition overlying the Pine Ridge Sandstone. Outcrop and core data also suggest a transition from a coastal plain environment into a lagoonal/estuarine and/or deltaic before marine deposition begins. This transition appears to occur again, changing from marine back to more proximal facies as part of a progradational highstand systems tract correlating well with a time-correlative coastal plain to the west of the basin at the Rock Springs Uplift. One last marine package is found at the top separated from the first by this progradational event. Transgression begins again on a large scale as accommodation likely outpaces sediment supply, creating a significant transgressive systems tract of preserved marine sandstones. These preserved sandstones are found in the subsurface and to some extent in outcrop at the Rock Springs Uplift. A deltaic influence is thought to be prevalent near the Rock Springs Uplift but especially closer to the south at the Cherokee Arch. It is also important to note that a deltaic influence may be responsible for much of the deposition throughout the Cherokee Arch as a potential deltaic influence is invoked at the Atlantic Ridge as well.

Deltaic reservoirs can be quite complex and their effectiveness as hydrocarbon reservoirs can depend on whether they are fluvial dominated or wave dominated. The Almond Formation marine sandstones have been studied and characterized to have been influenced by longshore drift and any delta would more likely be categorized as wave dominated (Kieft et al., 2011; Roehler, 1988). Deposition of a variable grain size within deltaic lobes as river discharge changes can cause compartmentalizing of reservoir sands by finer grains (Hart et al., 1997). This can cause issues with reservoir sweep as permeability can be negatively affected by baffles or barriers thus leading to hydrocarbon bypass (Tyler et al., 1987). This can be seen on a large scale with the shingled geometry of sands and mudstones in the subsurface near the Cherokee Arch (Figure 32). However, compartmentalization and depositional heterogeneity is a much smaller problem in a wave dominated as opposed to a fluvial dominated delta, because longshore drift effectively smears the fluvial signature removing complexity (Bhattacharya \& Sheriff, 2006). This often translates to higher hydrocarbon recoveries in wave dominated deltaic 
reservoirs (Tyler et al., 1987). To the extent that lagoonal or estuarine environments are a factor for the petroleum system, reservoir could experience more complexity. The implications for this added depositional environment are that stacking patterns may cause further isolation of sand bodies such as barrier islands, as lagoonal sediments could enhance local sealing mechanisms. Heterogeneity of reservoir may include washover fans, tidal inlet channels, and beach sands.

The use of sequence stratigraphy to define temporal shifts in relative sea-level helped to show the level of connectivity within each parasequence. Connectivity of parasequences of marine sands near the Atlantic Ridge seems to be poor as a result of the amount of finer grained sediment deposited between parasequences. However, the eastern extent of these marine sands is not well understood because of a lack of well control to the east of the current dataset. Analysis of current controlled data near Atlantic Ridge shows thinner sand geometry and more isolation, perhaps as a result of transgressive cannibalization and the presence of complex lagoonal and estuarine deposition. The well preserved transgressive systems tract that extends to outcrop in the west may include sand bodies that are in better communication. Each of these parasequences record a progradational pulse within the transgressive systems tract demonstrating a retrogradational backstepping pattern. The log motifs in the central Cherokee Arch (parasequences W1W6) show relatively thin deposits of fine grained sediment isolating the marine sands conveying the possibility of more communication between sands. However, the uppermost and westernmost two parasequences (W7, W8) appear to be very isolated from the others (W1-W6) within this transgressive systems tract.

\section{Conclusions}

Much is known about the Almond Formation to the north of the Cherokee Arch due to exploration along the Wamsutter Arch and in other areas. Many previous studies have characterized outcrop on both sides of the Washakie Basin, but most predominantly in the east of the field area, along the Rock Springs Uplift. Shoreface architecture and evolution have been mapped out in the upper Almond 
in some detail previously. However, little has been done to fully understand the distribution of marine sands moving basinward along the Cherokee Arch. This project has answered some questions about the location, distribution, and connectivity of potential reservoir. It has also proposed new ideas about paleodepositional environments and the nature in which the overall net-transgressive Almond Formation was deposited in space and time. Lateral facies changes, autogenic, allogenic, and tectonic processes have been discussed as potential drivers for observations made at outcrop and in the subsurface. Conclusions can be concisely summarized as followed:

- There is a thin outcrop of the upper Almond marine facies along the Atlantic Ridge at Deep Gulch that represents the initial stage of shoreline progradation and preservation after Sequence 1 begins.

- A careful and detailed description of a core taken very close to the outcrop at Atlantic Ridge proves that there is roughly 200 feet of marine progradation that cannot be characterized in outcrop. This core along with nearby well logs fill in this gap of knowledge.

- Sequence stratigraphic principles help to predict facies distributions. There evidence for several marine parasequences on the east side of the basin and analysis of subsurface data with regard to sequence stratigraphy yields a significant highstand systems tract topped with a major flooding surface. Immediately overlying the HST is a significant and impressively preserved transgressive systems tract that ends with the Lewis MFS (Asquith Datum) maximum flooding surface that the chronostratigraphic investigation was based on.

- Subsurface correlation with an emphasis on chronostratigraphy reveals a local increase in marine sand to the south of the Cherokee Arch while its chronostratigraphic counterpart to the north is shale. This may have reservoir implications and more well data is needed to map its extent.

- Shorelines can roughly be mapped to show their placement in plan-view but not accurately mapped for long lateral distances without more well control. Enough is known to suggest a general NW to SE trend. 
- Circumstantial evidence points to two incised valleys that are potentially filled as transgressions occur. Although, this is not known for sure, these interpreted valleys are located at interpreted sequence boundaries. Alternatively, they may be multi story distributary channel fill that would fit underneath the sequence boundary.

- Core, outcrop, and log data show that it is reasonable to interpret the depositional environment to the east of the basin during initial progradation of sequence 1 as a flooded estuarine environment with a deltaic influence.

- Sedimentary structures, trace fossil location and diversity, well log data, clinoformal geometries, and an extra deposited sand to the west suggest a strong deltaic influence that affects the stratigraphy of the Cherokee Arch.

\section{Future Work}

Acquisition of more well, outcrop, and core data for future work could help to solidify a few of these interpretations. Particularly, core data that is continuous would be helpful, as many of the Almond cores to the east are partial cores that do not convey necessary stacking pattern information. Another limitation to the east is access to private roads that lead to public land. There may be more useful outcrop to the east that is not available for research. 


\section{References}

Armstrong, R. L. (1968). Sevier orogenic belt in Nevada and Utah. Geological Society of America Bulletin, 79, 429-458.

Asquith, D. O. (1970). Depositional Topography and Major Marine Environments, Late Cretaceous, Wyoming. The American Association of Petroleum Geologists Bulletin, 54(7), 1184-1224.

Bhattacharya, J. P., \& Sheriff, R. E. (2006). Deltas. In SEPM Special Publication No. 84 (Vol. 84). SEPM (Society for Sedimentary Geology).

Blakey, R. C. (2014). Paleogeography and paleotectonics of the Western Interior Seaway, JurassicCretaceous of North America. American Association of Petroleum Geologists Search and Discovery, 30392(Article \#30392), 72pp.

Breithaupt, B. H. (1985). Nonmammalian Vertebrate Faunas from the Late Cretaceous of Wyoming. Wyoming Geological Association Guidebook, 36, 159-175.

Burch, D. N., \& Cluff, R. M. (1998). A Volumetric Analysis of Almond Formation (Cretaceous, Mesaverde Group) Gas Production in the Coal Gulch-Echo Springs-Standard Draw Field Complex, Washakie Basin, Southwest Wyoming. SPE Reservoir Engineering (Society of Petroleum Engineers), 1(4), 328-337.

Burst, J. F. (1965). Subaqueously Formed Shrinkage Cracks in Clay. SEPM Journal of Sedimentary Research, Vol. 35(2), 348-353. https://doi.org/10.1306/74d71271-2b21-11d7-8648000102c1865d

Dai, S., Bechtel, A., Eble, C. F., Flores, R. M., French, D., Graham, I. T., ... O’Keefe, J. M. K. (2020). Recognition of peat depositional environments in coal: A review. International Journal of Coal Geology, 219(December 2019), 103383. https://doi.org/10.1016/j.coal.2019.103383

Decelles, P. G. (1994). Late Cretaceous-Paleocene synorogenic sedimentation and kinematic history of the Sevier thrust belt, northeast Utah and southwest Wyoming. Geological Society of America 
Bulletin, 106(1), 32-56. https://doi.org/10.1130/0016-7606(1994)106<0032:LCPSSA>2.3.CO;2

DeCelles, P. G. (2004). Late Jurassic to Eocene evolution of the Cordilleran thrust belt and foreland basin system, western U.S.A. American Journal of Science, 304(2), 105-168.

https://doi.org/10.2475/ajs.304.2.105

Finn, T. M., \& Johnson, R. C. (2005). The Hilliard-Baxter-Mancos Total Petroleum System, Southwestern Wyoming Province. In U.S. Geological Survey Digital Data Series DDS-69-D.

Hart, B. S., Sibley, D. M., \& Flemings, P. B. (1997). Seismic stratigraphy, facies architecture, and reservoir character of a Pleistocene shelf-margin delta complex, Eugene Island Block 330 field, offshore Louisiana. American Association of Petroleum Geologists Bulletin, 81(3), 380-396.

Hettinger, R. D., \& Roberts, L. N. R. (2005). Lewis total petroleum system of the southwestern Wyoming province, Wyoming, Colorado, and Utah. In U.S. Geological Survey Digital Data Series.

Horn, B. W., \& Schrooten, R. A. (2001). Development of the Echo Springs-Standard Draw Field using technology to enhance an infill program, Washakie Basin, Wyoming. American Association of Petroleum Geologists Bulletin, 85, 171-188. https://doi.org/10.1306/8626e16b-173b-11d7$8645000102 \mathrm{c} 1865 \mathrm{~d}$

Kieft, R. L., Hampson, G. J., Jackson, C. A.-L., \& Larsen, E. (2011). Stratigraphic Architecture of a NetTransgressive Marginal- to Shallow-Marine Succession: Upper Almond Formation, Rock Springs Uplift, Wyoming, U.S.A. Journal of Sedimentary Research, 81(7), 513-533. https://doi.org/10.2110/jsr.2011.44

Knaust, D. (2017). Atlas of Trace Fossils in Well Core; Appearance, Taxonomy and Interpretation. In Atlas of Trace Fossils in Well Core. https://doi.org/10.1007/978-3-319-49837-9

Kovach, P. L., Caldaro-Baird, J. L., \& Wynne, P. J. (2003). Stagecoach draw field: Gas production from the Westernmost marine-influenced deposits of the Lewis Seaway transgression into Southwestern 
Wyoming. Mountain Geologist, 40(2), 35-53.

Leary, R., Decelles, P., Gehrels, G., \& Morriss, M. (2015). Fluvial deposition during transition from flexural to dynamic subsidence in the Cordilleran foreland basin: Ericson Formation, Western Wyoming, USA. Basin Research, 27(4), 495-516. https://doi.org/10.1111/bre.12085

Lichtner, D. T., Carnes, J. D., Wittke, S. J., \& Carroll, C. J. (2017). Preliminary Geologic Map of the Bridger Pass Quadrangle, Carbon County, Wyoming. Wyoming State Geological Survey Open File Report, 2017(6).

Lopez, J. L. (2014). Fluvial, shoreline, and clastic wedge responses to foreland basin and Laramide style subsidence : Examples from experimental studies and the Greater Green River Basin, southern Wyoming (The University of Texas at Austin). Retrieved from http://hdl.handle.net/2152/26608

MacEachern, J. A., Bann, K. L., Bhattacharya, J. P., \& Howell, C. D. (2011). Ichnology of deltas: organism responses to the dynamic interplay of rivers, waves, storms, and tides. In River DeltasConcepts, Models, and Examples. https://doi.org/10.2110/pec.05.83.0049

Martinsen, O. J., Ryseth, A., Helland-Hansen, W., Flesche, H., Torkildsen, G., \& Idil, S. (1999). Stratigraphic base level and fluvial architecture: Ericson Sandstone (Campanian), Rock Springs Uplift, SW Wyoming, USA. Sedimentology, 46(2), 235-259. https://doi.org/10.1046/j.13653091.1999.00208.x

Martinsen, R. S., \& Christensen, G. (1992). A Stratigraphic and Environmental Study of the Almond Formation, Mesaverde Group, Greater Green River Basin, Wyoming. Wyoming Geological Association Guidebook, 43rd, 171-190.

Mayorga-Gonzalez, L. C. (2016). Oil Potential of the Asquith Marker, Lewis Shale, Greater Green River Basin, Wyoming (University of Oklahoma). Retrieved from https://hdl.handle.net/11244/34693

Mei, M., Bissada, K. K. (Adry., Malloy, T. B., Darnell, L. M., \& Liu, Z. (2018). Origin of condensates 
and natural gases in the Almond Formation reservoirs in southwestern Wyoming, USA. Organic Geochemistry, 124, 164-179. https://doi.org/10.1016/j.orggeochem.2018.07.007

Miall, A. D., Galloway, W. E., Posamentier, H. W., Kendall, C. G. S. C., Strasser, A., Tucker, M. E., \& Catuneanu, O. (2011). Sequence Stratigraphy: methodology and nomenclature. Newsletters on Stratigraphy, 44(3), 173-245. https://doi.org/10.1127/0078-0421/2011/0011

Patruno, S., \& Helland-Hansen, W. (2018). Clinoforms and clinoform systems: Review and dynamic classification scheme for shorelines, subaqueous deltas, shelf edges and continental margins. EarthScience Reviews, 185(June), 202-233. https://doi.org/10.1016/j.earscirev.2018.05.016

Roehler, H. W. (1988). The pintail coal bed and barrier bar G - a model for coal of barrier bar-lagoon origin, Upper Cretaceous Almond Formation, Rock Springs coal field, Wyoming. US Geological Survey Professional Paper, 1398. https://doi.org/10.3133/pp1398

Roehler, Henry W. (1990). Stratigraphy of the Mesaverde Group in the central and eastern greater Green River Basin, Wyoming, Colorado, and Utah. United States Geological Survey Professional Paper, 1508, 52pp. Retrieved from http://www.osti.gov/energycitations/product.biblio.jsp?osti_id=5542339

Rudolph, K. W., Crabaugh, J. P., \& Devlin, W. J. (2015). Upper Cretaceous Sequence Stratigraphy of the Rock Springs Uplift, Wyoming 1. The Mountain Geologist, 52(3).

Schatzinger, R. A., \& Tomutsa, L. (1999). Multiscale heterogeneity characterization of tidal channel, tidal delta, and foreshore facies, Almond Formation outcrops, Rock Springs Uplift, Wyoming. In Reservoir Characterization-Recent Advances, AAPG Memoir (pp. 45-55). Retrieved from https://doi.org/10.1306/M711C4

Sturm, S., Evans, L., Keusch, B., \& Clark, W. (2001). Almond Formation reservoir characterization and sweet spot analysis in Siberia Ridge field, Wyoming. Gas in the Rockies, 145-170. Retrieved from http://archives.datapages.com/data/rmag/Gas_Rockies2001/sturm.pdf 
Swift, D. J. P. (1968). Coastal erosion and transgressive stratigraphy. The Journal of Geology, 76(4), 444-456.

Tobin, R. C., McClain, T., Lieber, R. B., Ozkan, A., Banfield, L. A., Marchand, A. M. E., \& McRae, L. E. (2010). Reservoir quality modeling of tight-gas sands in Wamsutter field: Integration of diagenesis, petroleum systems, and production data. American Association of Petroleum Geologists Bulletin, 94(8), 1229-1266. https://doi.org/10.1306/04211009140

Tyler, N., Gholston, J. C., \& Ambrose, W. A. (1987). Oil recovery in a low-permeability, wavedominated, Cretaceous, deltaic reservoir, Big Wells (San Miguel) Field, South Texas. American Association of Petroleum Geologists Bulletin, 71(10), 1171-1195.

https://doi.org/10.1306/703C8042-1707-11D7-8645000102C1865D

Van Wagoner, J. C., \& Mitchum, R. M. (2003). Siliciclastic sequence stratigraphy in well logs, cores, and outcrops: Concepts for high-resolution correlation of time and facies. American Association of Petroleum Geologists Methods in Exploration Series, 7. https://doi.org/10.1306/bf9ab431-0eb6$11 d 7-8643000102 \mathrm{c} 1865 \mathrm{~d}$ 
Appendix A: Drafted measured sections/core description

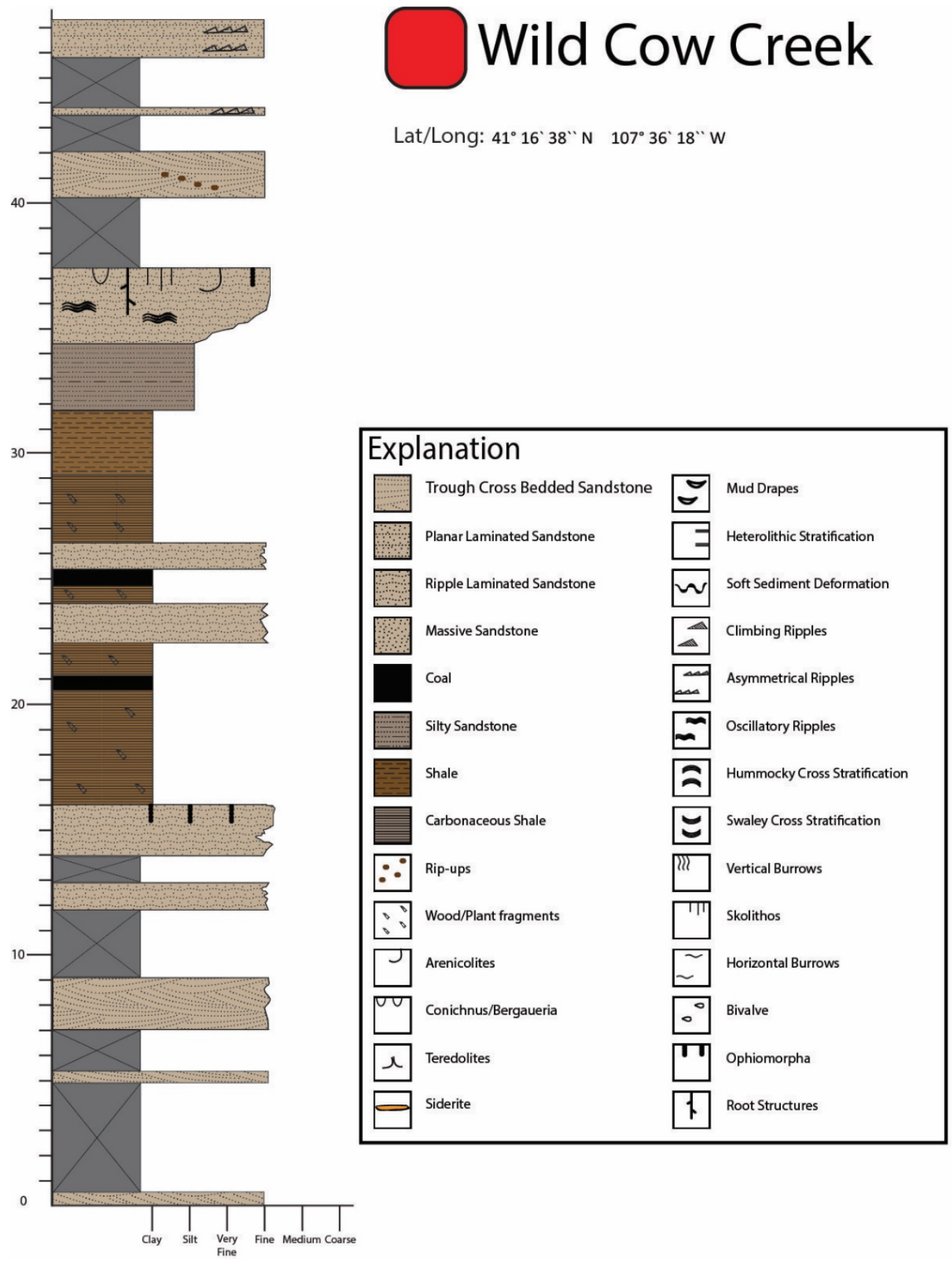




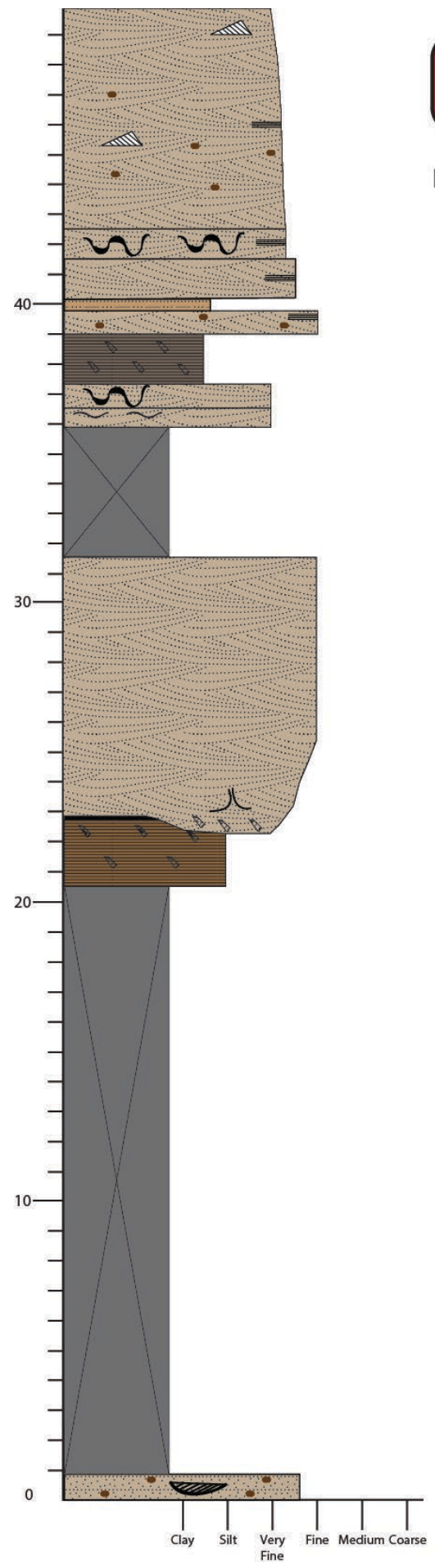

Deep Gulch \#4

Lat/Long: $41^{\circ} 18^{\prime} 53^{\prime \prime} \mathrm{N} \quad 107^{\circ} 34^{\prime} 50^{\prime \prime} \mathrm{W}$

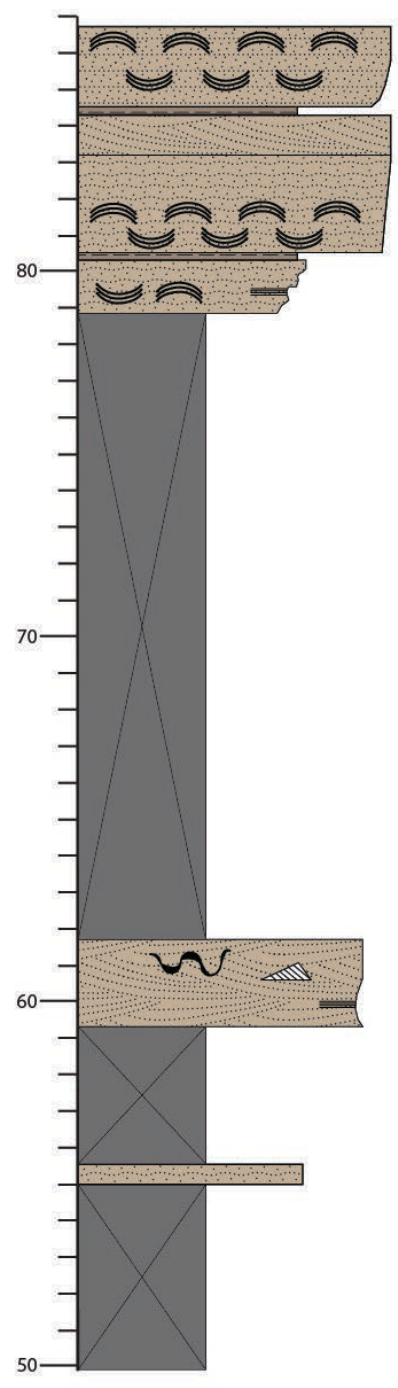




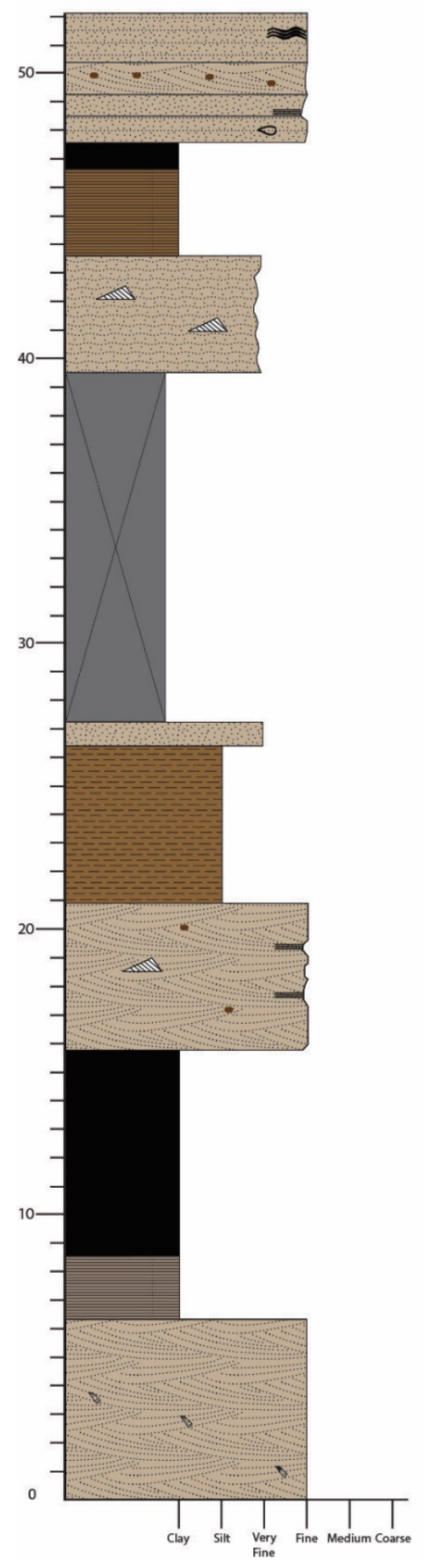

Lat/Long: $41^{\circ} 18^{\prime} 50^{\prime \prime} \mathrm{N} \quad 107^{\circ} 34^{\prime} 30^{\prime \prime} \mathrm{W}$

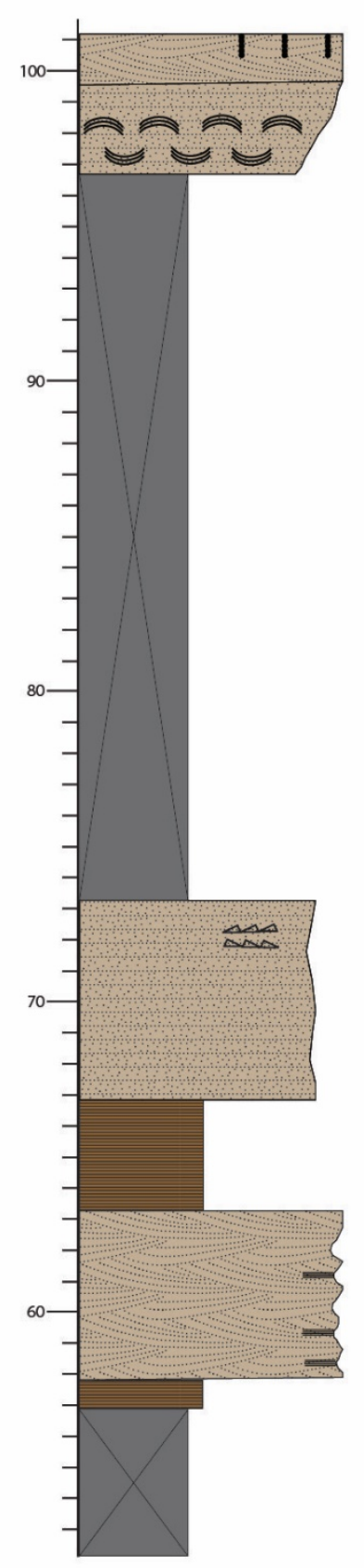




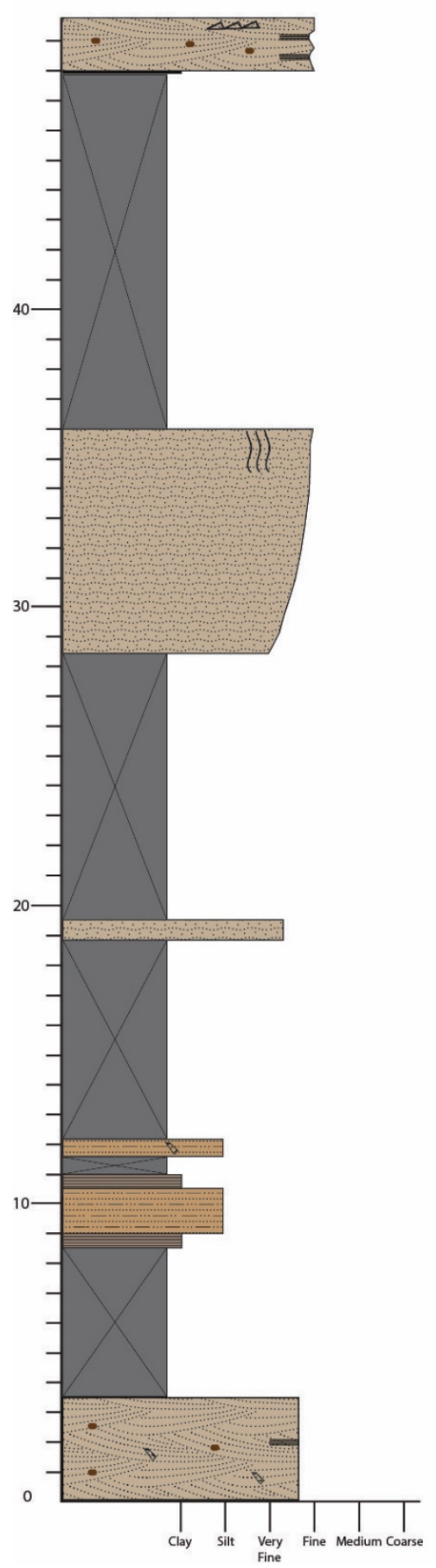

Lat/Long: $41^{\circ} 19^{\prime} 04^{\prime \prime} \mathrm{N} \quad 107^{\circ} 34^{\prime} 24^{\prime \prime} \mathrm{W}$

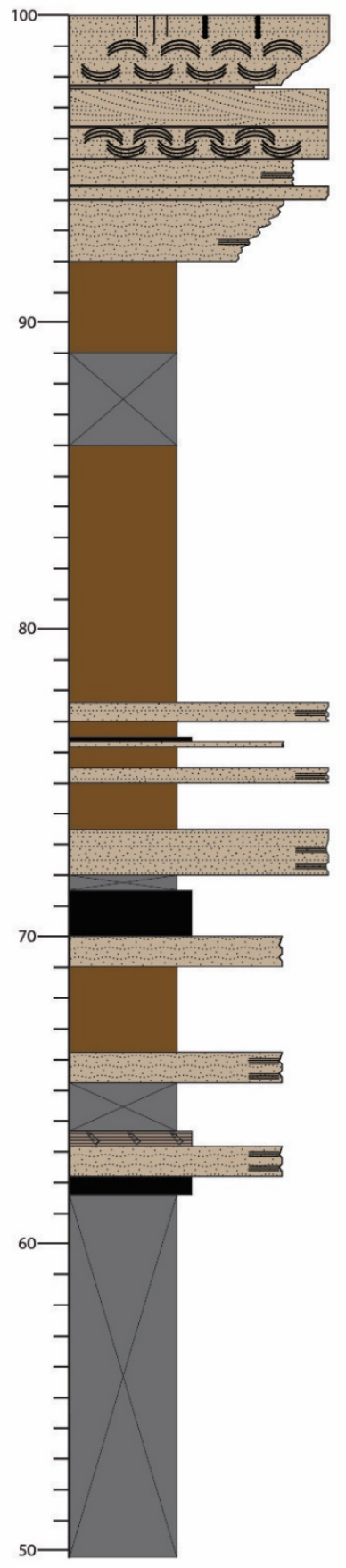




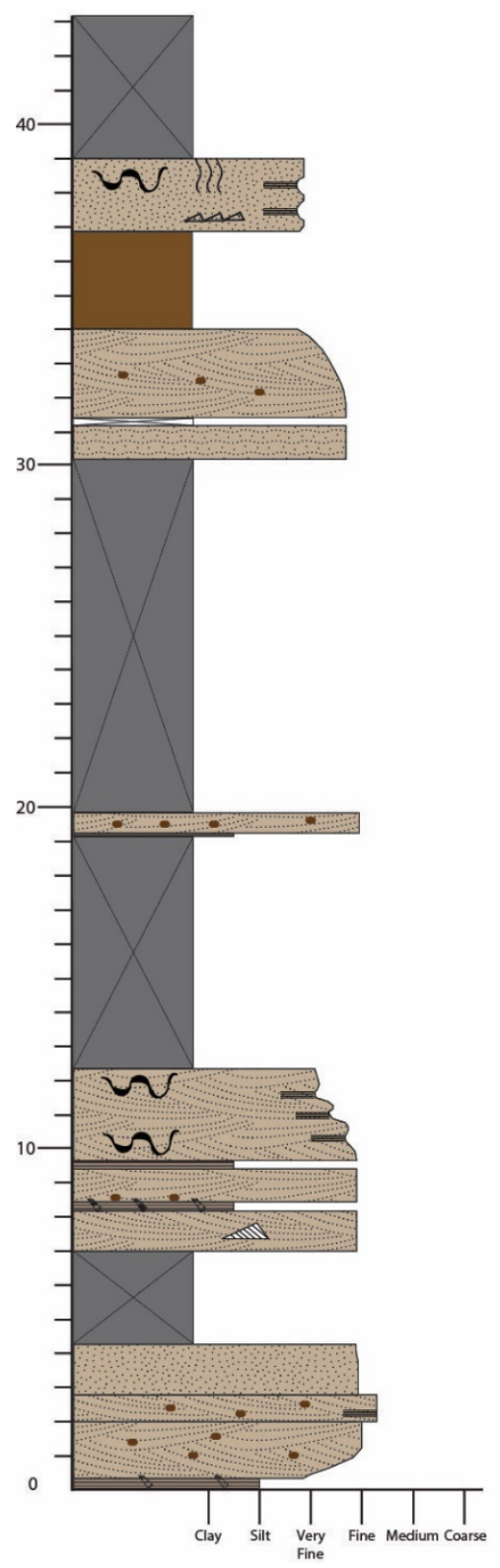

Lat/Long: $41^{\circ} 19^{\circ} 06^{\prime \prime} \mathrm{N} \quad 107^{\circ} 34^{\prime} 21^{\prime \prime} \mathrm{W}$

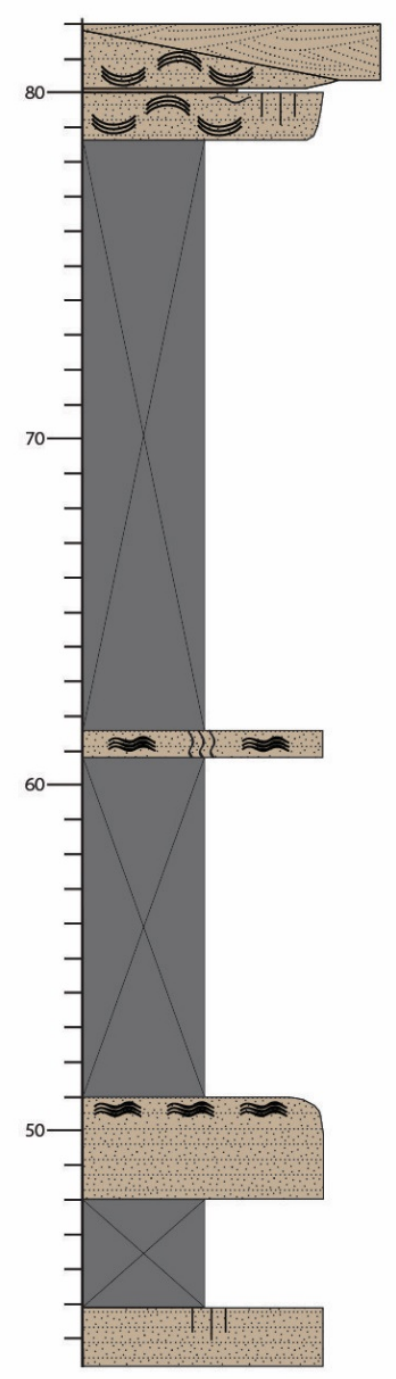




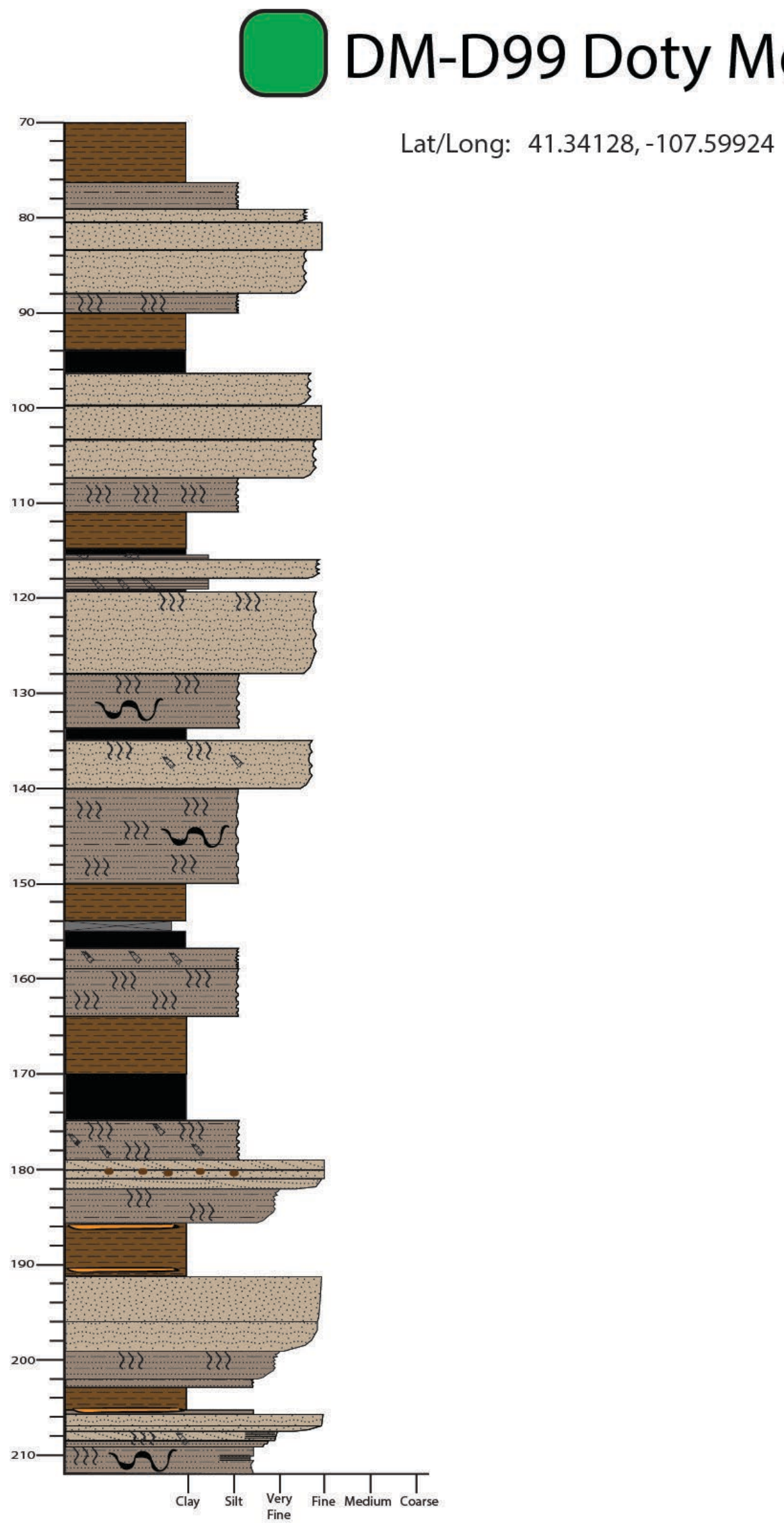




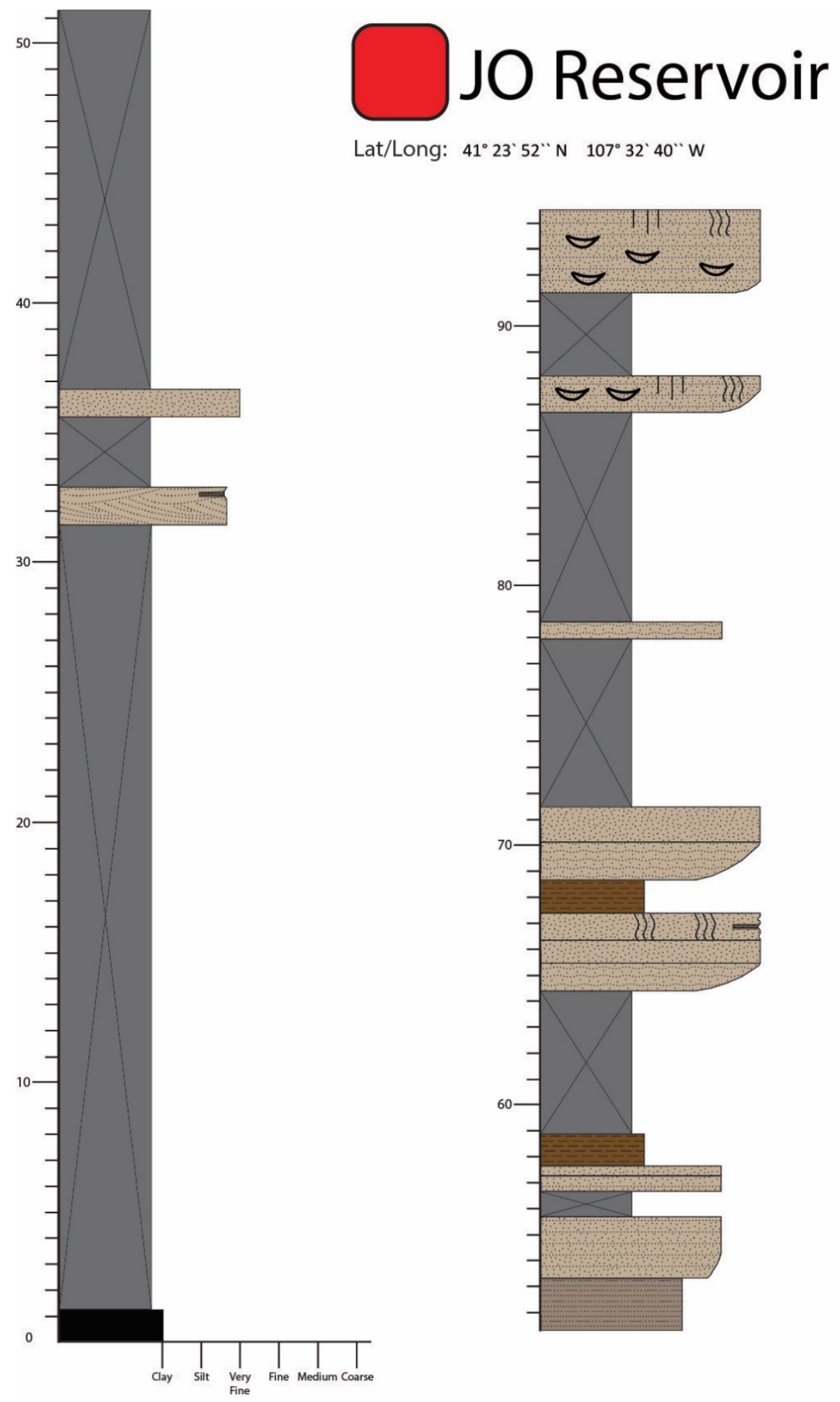



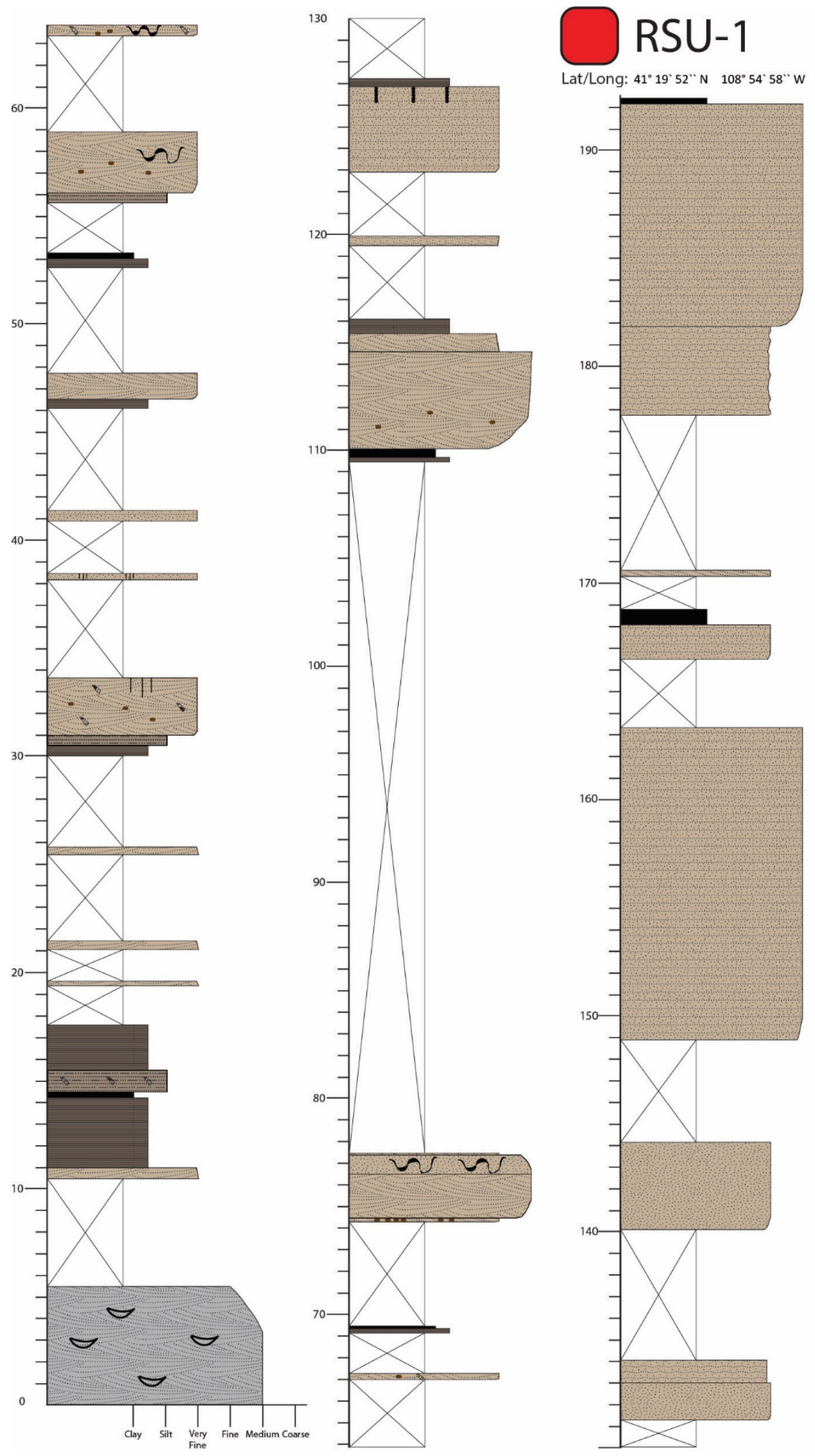
RSU-2

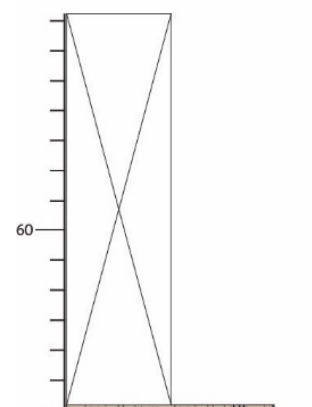

Lat/Long: $41^{\circ} 20^{\circ} 00^{\prime \prime} \mathrm{N} \quad 108^{\circ} 54^{\circ} 56^{\prime \prime} \mathrm{W}$
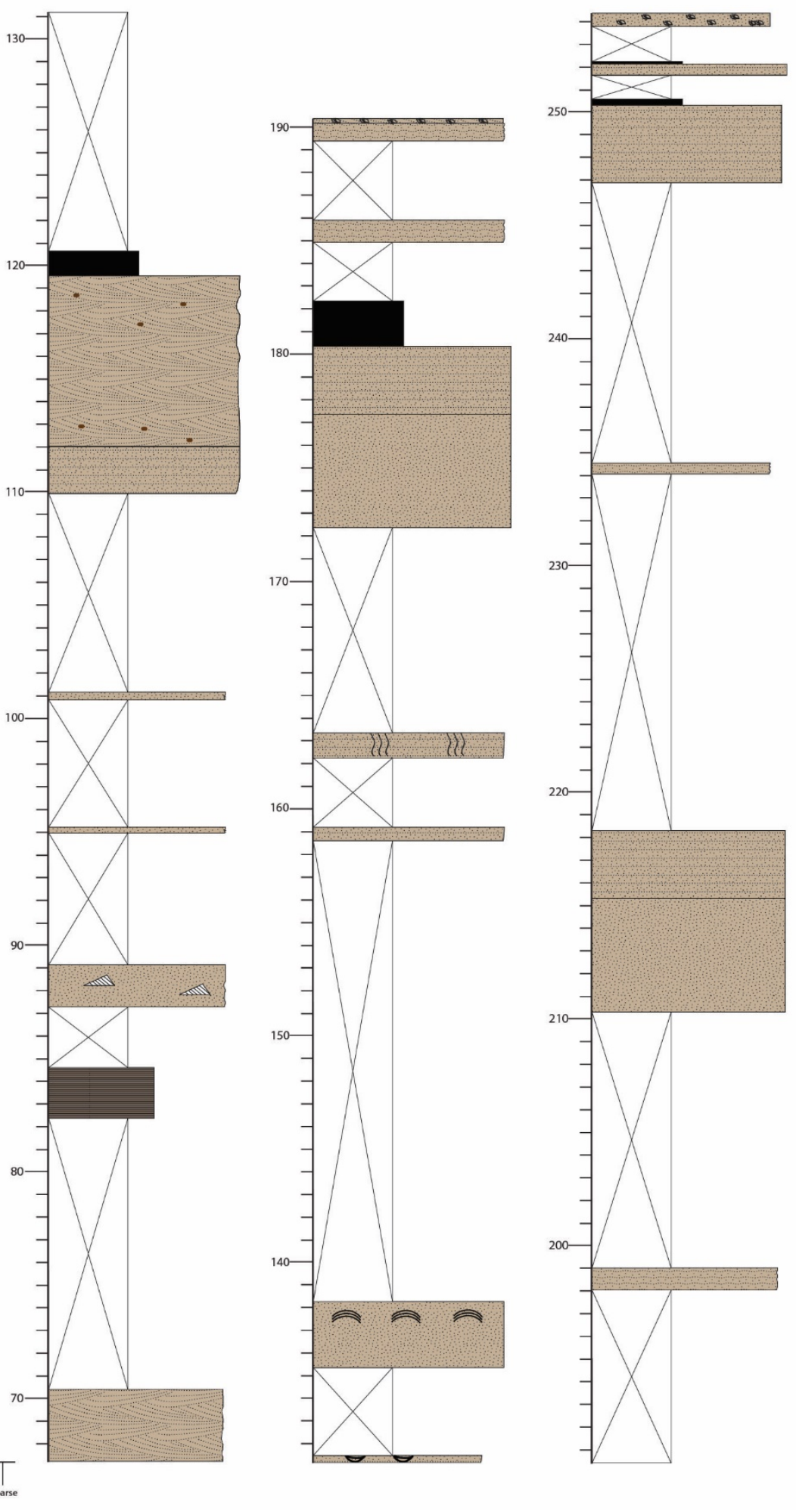


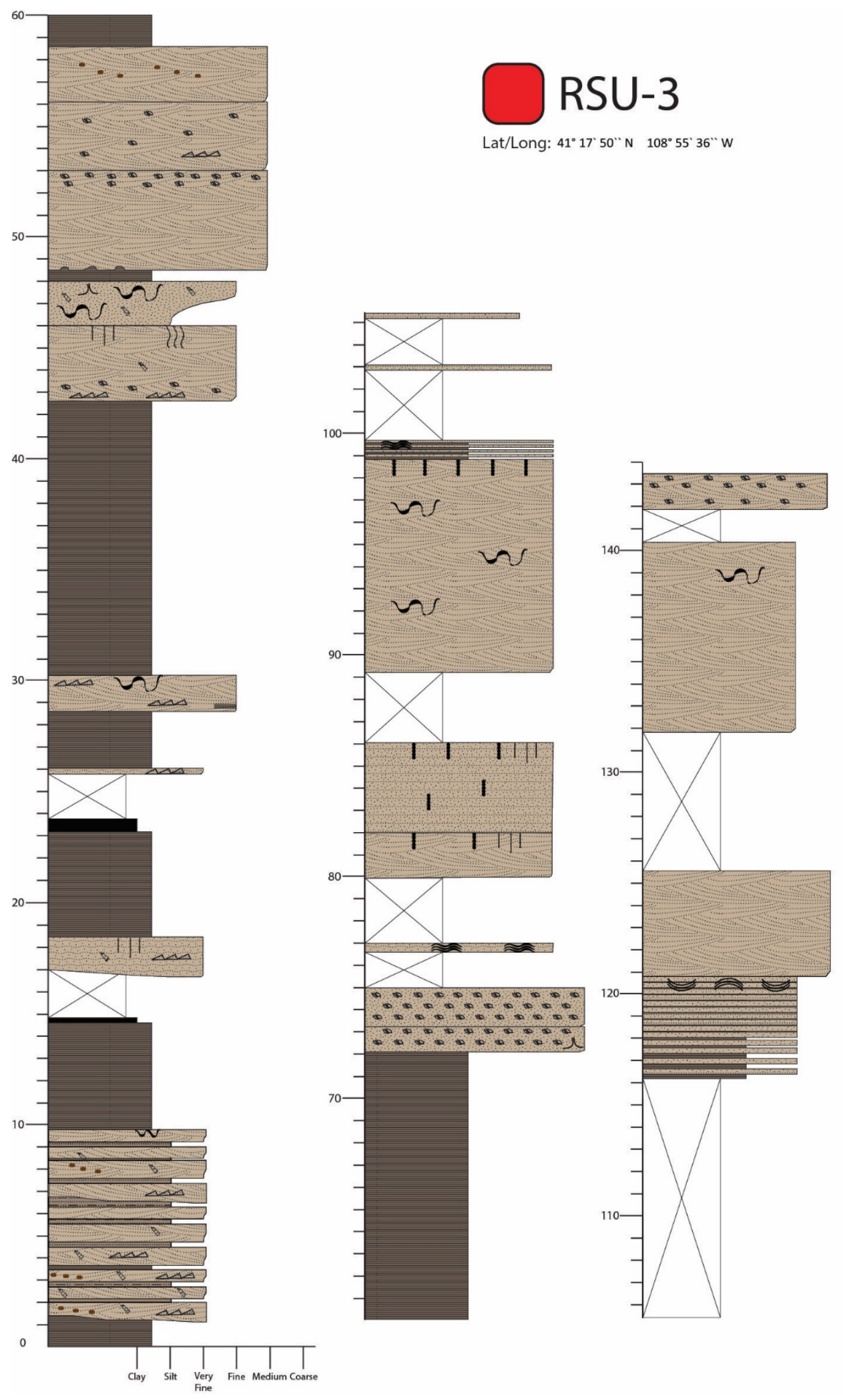


Appendix B: Well Locations

\begin{tabular}{|c|c|c|c|}
\hline Well ID & Well Name & Latitude & Longitude \\
\hline 49037205140000 & FEDERAL & 41.00339 & -108.564489 \\
\hline 49037268730000 & ALKALI GULCH UNIT & 41.046843 & -108.652086 \\
\hline 49007215300000 & WILD COW CREEK UNIT & 41.261667 & -107.612899 \\
\hline 5081060060000 & UNION & 40.980765 & -108.06074 \\
\hline 49037235270000 & POLAR BAR UNIT & 41.143777 & -108.175904 \\
\hline 49007214090000 & CEDAR BREAKS & 41.128502 & -107.804867 \\
\hline 49007202850000 & CIGE FEDERAL & 41.111075 & -107.851938 \\
\hline 5081068520000 & LITTLE SNAKE FEDERAL & 40.981493 & -108.067896 \\
\hline 49037231690000 & BLACK BAR & 41.073503 & -108.141544 \\
\hline 49037264130000 & SOUTH BLUEWATER FED & 41.039636 & -108.27854 \\
\hline 49037212560000 & FIREPLACE ROCK UNIT & 41.00558 & -108.091641 \\
\hline 49007223900000 & NORTH BAGGS STATE & 41.050554 & -107.692435 \\
\hline 49037248910000 & READER CABIN & 41.102501 & -108.104066 \\
\hline 49037219220000 & TRITON UNIT & 41.11854 & -108.11511 \\
\hline 49037257020000 & SOUTH BLUEWATER UNIT & 41.04455 & -108.284829 \\
\hline 49007223820000 & GAMBLERS RES. FED. & 41.051197 & -107.768957 \\
\hline 49037208570000 & FEDERAL & 41.005267 & -107.92988 \\
\hline 5081068860000 & RACETRACK STATE & 40.997134 & -108.421805 \\
\hline 49007223390000 & ROBBERS GULCH & 41.139647 & -107.732362 \\
\hline 49037247080000 & POWDER MOUNTAIN ST & 41.096088 & -108.208688 \\
\hline 49037218830000 & MCPHERSON SPRINGS B & 41.075394 & -107.942956 \\
\hline 49007224540000 & NORTH GAMBLERS FED & 41.068721 & -107.754582 \\
\hline 49037223170000 & NEW MOON UNIT & 41.092756 & -108.041184 \\
\hline 49007050330000 & GOVT & 41.049606 & -107.708004 \\
\hline 49037216430000 & $\mathrm{CIGE}$ & 41.122429 & -108.247758 \\
\hline 5081061470000 & FEDERAL-TRUE & 40.984154 & -108.103579 \\
\hline 49007222840000 & ROBBERS GULCH & 41.136277 & -107.759399 \\
\hline 49007211610000 & PRONGHORN & 41.114718 & -107.768276 \\
\hline 49037229910000 & BOGEY DRAW & 41.092665 & -108.06672 \\
\hline 49037064190000 & CHEROKEE RIDGE 1 & 41.035344 & -108.187252 \\
\hline 5081068560000 & FIREPLACE UNIT & 40.995505 & -108.004571 \\
\hline 5081072190000 & COFFEPOT SPRINGS (OWP) & 40.950914 & -108.392935 \\
\hline 49007238140000 & SD FEDERAL & 41.347059 & -107.625546 \\
\hline 49007214770000 & RED CREEK & 41.093951 & -107.90272 \\
\hline 49037231170000 & CEPO & 41.137897 & -108.084872 \\
\hline 5081063140000 & SHELL CREEK & 40.958574 & -108.508273 \\
\hline 49007207910000 & POSEIDON UNIT & 41.070682 & -107.889977 \\
\hline 49007210900000 & RED CREEK & 41.050713 & -107.873949 \\
\hline 49007223320000 & BLUE HAYSTACK UNIT & 41.108938 & -107.901835 \\
\hline
\end{tabular}




\begin{tabular}{|c|c|c|c|}
\hline 5081066220000 & DEEP & 40.971769 & -108.315741 \\
\hline 5081062230000 & FEDERAL & 40.998655 & -108.04125 \\
\hline 49007200520000 & CHRISTENSEN RANCH & 41.012296 & -107.804712 \\
\hline 5081054700000 & ALLEN, C. "A" & 40.953203 & -108.298351 \\
\hline 49037217410000 & MCPHERSON SPRINGS & 41.103871 & -107.943817 \\
\hline 49037267100000 & CANYON CREEK & 41.062819 & -108.728589 \\
\hline 49037259210000 & CROOKED WASH UNIT & 41.017393 & -108.435812 \\
\hline 49037223430000 & NEWMAN & 41.09394 & -108.017083 \\
\hline 49037244760000 & PECTIN CREEK UNIT & 41.025342 & -108.336413 \\
\hline 49007207800000 & NORTH BAGGS-FEDERAL & 41.050539 & -107.731452 \\
\hline 49037224230000 & MARS STATE & 41.009375 & -107.981941 \\
\hline 49007238120000 & AR FEDERAL & 41.396219 & -107.608976 \\
\hline 49007200510000 & CLARK W-0318081 & 41.037794 & -107.857539 \\
\hline 5081070110000 & ABCO INC GOV & 40.996394 & -108.443015 \\
\hline 49007232100000 & AR STATE & 41.276578 & -107.631226 \\
\hline 49037228620000 & ALMOND JOY & 41.082341 & -107.978722 \\
\hline 49037213450000 & MCPHERSON SPRINGS & 41.089539 & -107.944383 \\
\hline 49007206820000 & CIGE FEDERAL & 41.138129 & -107.797622 \\
\hline 49037203150000 & USA AMOCO K & 41.016629 & -108.201547 \\
\hline 49007205780000 & SATURN UNIT & 41.070648 & -107.852437 \\
\hline 5081070000000 & EOG POWDER WASH & 40.929289 & -108.295922 \\
\hline 5081074590000 & RESERVOIR DRAW & 40.951488 & -108.226633 \\
\hline 5081074590200 & RESERVOIR DRAW & 40.951488 & -108.226633 \\
\hline 5081074590100 & RESERVOIR DRAW & 40.951488 & -108.226633 \\
\hline 49007203110000 & STRECKFUS DRAW & 41.138162 & -107.700937 \\
\hline 49037266970000 & ALKALI GULCH UNIT & 41.024333 & -108.625234 \\
\hline 49007232550000 & CHEROKEE DRAW FED & 41.118267 & -107.81403 \\
\hline 5081074380000 & CHEROKEE RIDGE & 40.995035 & -108.024912 \\
\hline 5081070930000 & TWO RIM UNIT & 40.986017 & -108.017103 \\
\hline 49007217780000 & FEDERAL & 41.101748 & -107.883754 \\
\hline 49037219990000 & POWDER MOUNTAIN & 41.017102 & -108.364649 \\
\hline 49007224390000 & BLUE HAYSTACK UNIT & 41.126448 & -107.907488 \\
\hline 49037050610000 & POWDER MTN UNIT & 41.024172 & -108.340516 \\
\hline 49007233870000 & AR FEDERAL & 41.312869 & -107.642095 \\
\hline 49007229090000 & BLUE GAP II UNIT & 41.20845 & -107.809955 \\
\hline 49037050390000 & FEDERAL-DAMEWOOD & 41.009885 & -108.40265 \\
\hline 49037232380000 & ROLLING GREEN & 41.046398 & -107.943224 \\
\hline 49007210170000 & Browning & 41.2152149 & -107.5895757 \\
\hline 49007231990000 & Wild Horse & 41.1822865 & -107.677905 \\
\hline 49037052150000 & NJ Blum & 41.2529151 & -108.9227317 \\
\hline 49037255180000 & PRState $15101 \mathrm{NE}$ & 41.2407982 & -108.8391414 \\
\hline
\end{tabular}




\begin{tabular}{|l|l|r|r|}
49037260080000 & PR FED 15101 SW29 & 41.2475286 & -108.8104888 \\
\hline 49037260540000 & PR FED 15101 SE29 & 41.2472449 & -108.8010912 \\
\hline 49037255370000 & PR FED 15101 NW32 & 41.2408066 & -108.8108593 \\
\hline 49037251200000 & RIFES RIM 1-18 & 41.1984197 & -108.8174208 \\
\hline 49037288760000 & Whiskey Canyon Unit 16-13 & 41.10131 & -108.72265 \\
\hline
\end{tabular}

